UNITED STATES DEPARTMENT OF THE INTERIOR

J. A. Krug, Secretary

GEOLOGICAL SURVEY

W. E. Wrather, Director

\title{
Bulletin 951
}

\section{GEOLOGY OF THE \\ GREEN RIVER DESERT-CATARACT CANYON REGION \\ EMERY, WAYNE, AND GARFIELD COUNTIES \\ UTAH}

$-\quad B Y$

ARTHUR A. BAKER

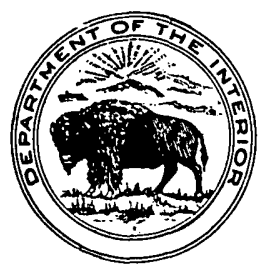

UNITED STTATES

GOVERNMENT PRINTING OFFICE

WASHINGTON : 1946

For sale by the Superintendent of Documents, U. S. Government Printing Office, Washington 25, D. C. Price $\$ 2.00$ 



\section{CONTENTS}

Abstract Page

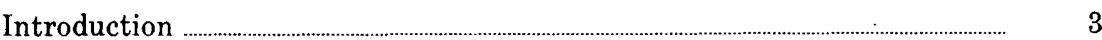

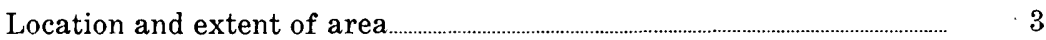

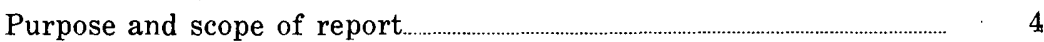

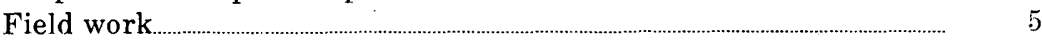

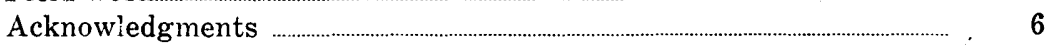

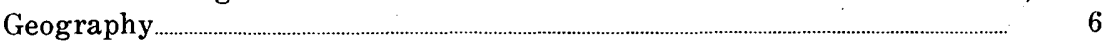

Surface features ...................................................................................................................

Drainage and water supply ...............................................................................

Climate and vegetation ……................................................................................... 15

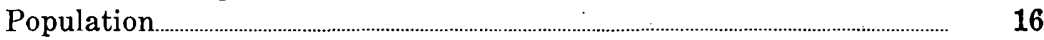

Accessibility and routes of travel ………........................................................ 18

Previous publications .................................................................................................................. 19

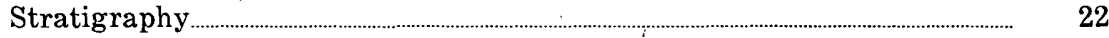

General features ................................................................................................. 22

Carboniferous system................................................................................................ 23

Pennsylvanian series.......................................................................................... 23

Paradox formation ................................................................................. 23

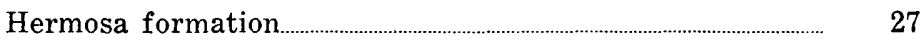

Permian system......................................................................................................................... 32

General features ................................................................................... 32

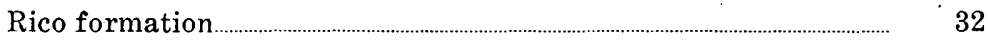

Post-Rico Permian formations ………………............................................... 36

Cutler formation.

Cedar Mesa sandstone member ….......................................... $\quad 37$

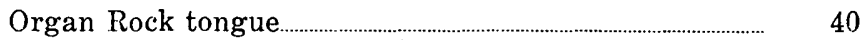

White Rim sandstone member ........................................................ 44

Coconino sandstone.................................................................................... 48

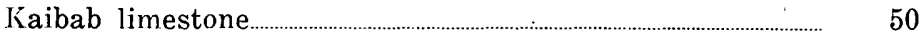

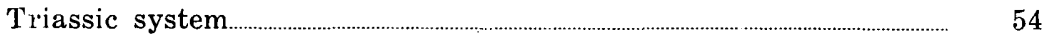

Lower Triassic series ……......................................................................... 54

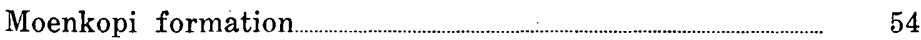

Upper Triassic'series

Shinarump conglomerate ............................................................................ 58

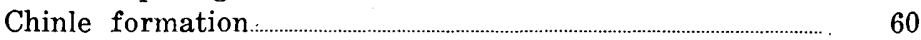

Jurassic( ?) system..............................................................................................

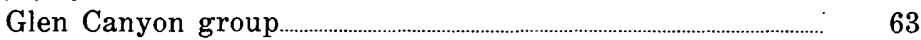

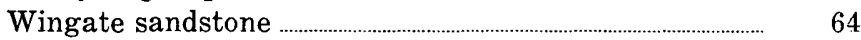

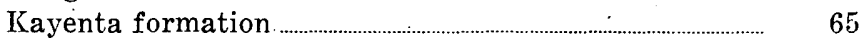

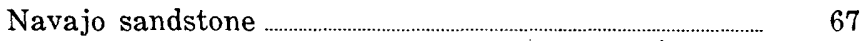

Jurassic system._.

Upper Jurassic series

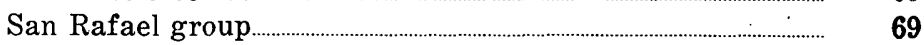

Carmel formation ....................................................................................

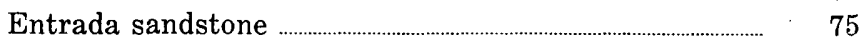

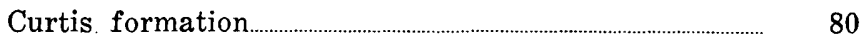

Summerville formation................................................................. $\quad 84$

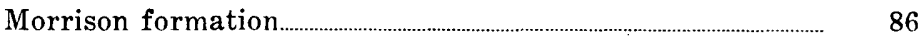


Stratigraphy-Continued.

Cretaceous system

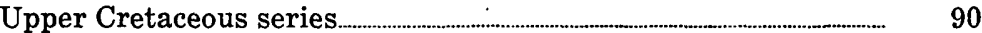

Dakota ( ?) sandstone ............................................................. 90

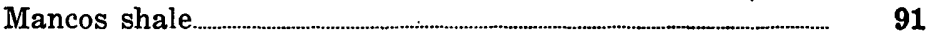

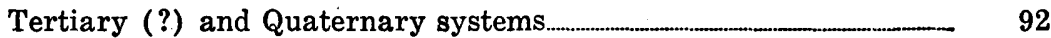

Structure

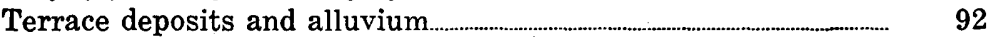

Methods of representing structure.

Details of the folds

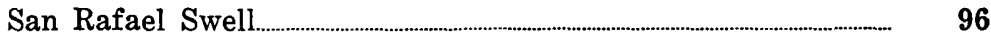

Monument upwarp........................................................................................... $\quad 97$

Anticlines in the vicinity of the Emery-Wayne County line.......... $\quad 97$

Flattop Buttes anticline and subsidiary Big Flattop Butte and Sweetwater domes.

Barrier Creek anticline.

Whitbeck Knoll anticlinal nose ..................................................................

Attitude of the rocks in the northern part of the Green River Desert.

Folds and faults related to flowage in the Paradox formation.. Faults

Periods of deformation

History of drilling

Records of wells

\section{ILLUSTRATIONS}

Plate 1. Geologic map and section of the Green River DesertCataract Canyon region, Emery, Wayne, and Garfield Counties, Utah In pocket

2. Structural geologic map of the Green River DesertCataract Canyon region, Emery, Wayne, and Garfield Counties In pocket

3. Generalized columnar section of the rocks exposed in the Green River Desert-Cataract Canyon region

4. $A$, View upstream along Cataract Canyon; $B$, Near view of gypsum plug shown in plate $4, A$, looking downstream in tributary canyon.

5. $A$, View of head of Cataract Canyon; $B$, Mille Crag Bend near lower end of Cataract Canyon

6. $A$, Aerial view of junction of the Green and Colorado Rivers; $B$, Aerial view of dissected surface west of mouth of Green River with Elaterite Butte in foreground

7. Sections showing lateral variations of the Cutler and Moenkopi formations along the canyons of the Green and Colorado Rivers. 


\section{ILLUSTRATIONS}

Plate 8. Diagram showing interpretation of the correlation of the Cutler formation exposed along the Green and Colorado Rivers with the Kaibab limestone and Coconino sandstone of the San Rafael Swell and Circle Cliffs.

9. A, Dissected Cedar Mesa sandstone bench southwest of the mouth of Green River; $B$, Red and white banded Cedar Mesa sandstone member of the Cutler formation near edge of river canyon, west of mouth of Green River.

10. $A$, Wedging out of the White Rim sandstone member of the Cutler formation at the head of Range Canyon; $B$, Mouth of the Dirty Devil River.

11. A, Standing Rock on the trail to Spanish Bottom; $B$, Typical outcrop of the lower part of the Moenkopi formation on the crest of the San Rafael Swell; $C$, The Cutler formation in Horse Canyon northwest of Elaterite Butte.

12. $A$, Outcrop of the Moenkopi formation in Elaterite Basin; $B$, Aerial view southeast from Millard Canyon. erial view southwest from the San Rafael River at the Reef

14. Aerial view south along the Reef from Black Dragon Canyon

15. Aerial view, upstream, of Labyrinth Canyon in vicinity of the Bowknot

16. Aerial view of the east front of the San Rafael Swell south of the San Rafael River.

17. A, Basal limy bed of the Carmel formation resting upon a slightly irregular surface of the Navajo sandstone at Straight Wash; $B$, Contact between the Carmel formation and the overlying Entrada sandstone about 4 miles southwest of the mouth of the San Rafael River; $C$, Contorted bedding in the Entrada sandstone half a mile west of Cabin Spring .

18. $A$, North point of the Big Flattop Butte; $B$, Banded variegated shale in the upper part of the Morrison formation along the Green River-Hanksville road about 2 miles north of the San Rafael River.

19. $A$, West wall of Cataract Canyon southeast of Wide Valley; $B$, View north along Surprise Valley, a graben valley adjacent to Cataract Canyon.

20. Map showing geologic structure of southeastern Utah

Figure 1. Index map of Utah showing location of the Green River Desert-Cataract Canyon region and its relation to neighboring areas described in other reports...

2. Generalized diagram showing the stratigxaphic relation of the Kaibab limestone to the upper part of the Coconino sandstone and the Cutler formation between Marysvale and Salt Valley, Utah.

iagrammatic cross section of the Carmel-Entrada contact on the east side of Moonshine Canyon. 



\title{
GEOLOGY OF THE GREEN RIVER DESERT-CATARACT CANYON REGION, EMERY, WAYNE, AND GARFIELD COUNTIES, UTAH
}

\author{
By ARTHur A. BAKER
}

\begin{abstract}
ABS'TR ACT
The Green River Desert-Cataract Canyon region includes about 2,150 square miles of sparsely populated, semiarid, canyon and plateau country in Emery, Wayne, and Garfield Counties, Utah. Situated west of the Green and Colorado Rivers, it extends from the Dirty Devil River on the south to the Denver and Rio Grande Western Railroad on the north and includes the eastern part of the San Rafael Swell. The rivers and most of their tributaries flow through deep canyons, which have been cut into a northward-sloping upland surface, and the huge dome of the San Rafael Swell rises above this upland surface with an abrupt eastward-facing escarpment. The altitudes of surface features above sea level range from about 3,500 feet at the mouth of the Dirty Devil River to a maximum of about 7,000 feet at the southern margin of the upland surface and on the summit of the San Rafael Swell; the altitude of the upland surface decreases to about 4,100 feet at the north boundary of the area. The region abounds in unusual scenic features especially in that part adjacent to the Green, Colorado, and Dirty Devil Rivers, where vari-colored rocks, practically unobscured by soil and vegetation, crop out in the walls of numerous canyons, including Cataract Canyon of the Colorado River, and in high steep cliffs, and in many domes, mesas, and spires.
\end{abstract}

Green River, the only town in the area, is located on the main line of the Denver and Rio Grande Western Railroad. Only about 25 people live in the area beyond the limits of the town. Farming and stock raising are the principal industries, but the farming is limited to small areas of irrigated land near the town of Green River and along the San Rafael River.

The aggregate average thicknesses of the formations exposed in the area is 6,500 feet, and they range in age from Pennsylvanian to Upper Cretaceous. The oldest exposed rocks crop out in Cataract Canyon as plugs of gypsum, derived from the Paradox formation of lower Pennsylvanian age, which have been forced through a thin cover of the overlying rocks. Only the upper part of the overlying Pennsylvanian Hermosa formation is exposed. It consists of marine, dominantly gray, massive sandstone and limestone and some shale. The overlying Permian Rico formation consists of interbedded sandstone, shale, siltstone, and limestone; it is about 575 feet thick in Cataract Canyon but may be absent in the San Rafael Swell in the western part of the area. Permian rocks younger than the Rico in the eastern part of the area are included in the Cutler formation, about 1,100 feet thick, which is composed of massive buff to gray sandstone interbedded with red siltstone and sandstone, but in the San Rafael Swell the post-Rico Permian is divided into the thick massive buff to gray Coconino sandstone, nearly 700 feet thick, and the thin overlying Kaibab limestone. The Lower Triassic Moenkopi formation rests upon an erosion surface at the top of the Permian; it has a maximum thickness of nearly 700 feet and consists of thin regularly bedded, dominantly red sandstone and shale and in the San Rafael Swell contains the Sinbad limestone 
member in the lower part. The relatively thin Shinarump conglomerate of Upper Triassic age unconformably overlies the Moenkopi formation and grades upward into the Upper Triass:c Chinle formation, which has a maximum thickness of about 450 feet and consists of variegated shale with subordinate sandstone and conglomerate.

Conformably overlying the Chinle formation is the Jurassic (?) Glen Canyon group, which includes at the base the massive reddish-tan Wingate sandstone, about 300 feet thick, and at the top the massive gray to buff markedly cross-bedded Navajo sandstone about 500 feet thick separated by the irregularly bedded red to gray sandstone of the Kayenta formation with a thickness of about 275 feet. The overlying San Rafael group of Upper Jurassic age includes the Carmel formation at the base 80 to 230 feet thick consisting of red to gray silty sandstone and shale, with some limestone and locally with abundant gypsum, overlain successively by (1) the red to gray Entrada sandstone, about 400 feet thick; (2) the Curtis formation, which has a maximum thickness of 235 feet and is composed of greenish-gray glauconitic sandstone and shale; and at the top of the group (3) the Summerville formation, 100 to 200 feet thick consisting of red and gray shale, mudstone, and subordinate platy sandstone in thin regular beds. The Morrison formation, about 600 feet thick, is the youngest Jurassic formation in the area and unconformably overlies the Summerville, locally with angular discordance; the lower Salt Wash sandstone member consists of irregularly bedded gray to brown, somewhat conglomeratic sandstone interbedded with red to gray shale and mudstone and some gypsum, and the upper part of the formation consists of variegated mudstone and siltstone with several beds of siliceous conglomeratic sandstone.

The Dakota (?) sandstone at the base of the Upper Cretaceous is thin and discontinuous and fills depresssions on an eroded surface of the Morrison; it consists of bright yellowish-brown conglomerate and sandstone with some gray and black shale. The overlying Mancos shale is composed of blue-gray shale with a few thin beds of sandstone.

The most conspicuous structural feature in the area is the steeply dipping east flank of the San Rafael Swell, which is a huge north trending regional upwarp about 100 miles long. The southern part of the area includes part of the gently dipping northern end of the Monument upwarp, which is a structural feature comparable in size and trend to the San Rafael Swell. A low structural ridge extends southeastward from the San Rafael Swell in the vicinity of the Emery-Wayne County line. North of this structural ridge the rocks dip gently northward into the Uinta Basin; southwest of it they dip gently into the large synclinal basin containing the Henry Mountains. The rocks are broken by numerous normal faults most of which are steeply dipping, have small displacements, and trend N. $45^{\circ}$ to $65^{\circ} \mathrm{W}$.

The most important period of folding, during which most of the surface rocks acquired their present attitudes, is believed to have occurred in late Cretaceous time, but important structural movements also occurred at other times. Scanty evidence from drilled wells suggests that Pennsylvanian sediments overlap upon an eroded surface of folded pre-Pennsylvanian rocks. Arching of the rocks and faulting along the upper part of Cataract Canyon occurred very recently in geologic time after the surface of the region had acquired essentially its present form. This structural disturbance is ascribed to flowage of the plastic material of the Paradox formation from areas adjacent to the canyon, where it was under the pressure of the weight of a thickness of 2,000 feet or more of overlying formations, into the arch along 
the canyon, where it was confined by only a thin cover of the overlying rocks.

Several wells have been drilled for oil or gas within the area, but commercial production has not been obtained. Showings of oil or gas have been found at several horizons, especially in the upper part of the Permian and in the lower part of the Lower Triassic. Wells have been drilled into rocks believed to be of Mississippian age and a well drilled on the San Rafael Swell reached granitic rocks after passing through Mississippian(?) and possibly older formations.

\section{IN'TRODUC'IION}

\section{LOCATION AND EXTENT OF THE AREA}

The Green River Desert-Cataract Canyon region is in eastern Emery, Wayne, and Garfield Counties in southeastern Utah. Bounded by the Green and Dirty Devil Rivers it extends northwestward from Cataract Canyon of the Colorado River to the crest of the San Rafael Swell and to the Denver \& Rio Grande Western Railroad in the vicinity of the town of Green River. It includes an area of about 2,150 square miles. The location of the Green River Desert-Cataract Canyon region and its relation to neighboring areas in southeastern Utah that have been described in other Geological Survey publications are shown in figure 1. The publications in which the geology of the areas designated by numbers on the index map is described are as follows:

1. This report.

2. Gregory, H. E., and Moore, R. C., The Kaiparowits region, a geographic and geologic reconnaissance of parts of Utah and Arizona: U. S. Geol. Survey Prof. Paper 164, 1931.

3. Baker, A. A., Geology of the Monument Valley-Navajo Mountain region, San Juan County, Utah: U. S. Geol. Survey Bull. 865, 1936.

4. Gregory, H. E., Geology of the Navajo country-a reconnaissance of parts of Arizona, New Mexico, and Utah: U. S. Geol. Survey Prof. Paper 93, 1917.

5. Gregory, H. E., The San Juan country, a geographic and geologic reconnaissance of southeastern Utah: U. S. Geol. Survey Prof. Paper 188, 1938.

6. Baker, A. A., Geology and oil possibilities of the Moab district, Grand and San Juan Counties, Utah: U. S. Geol. Survey Bull. 841, 1933.

7. McKnight, E. T., Geology of area between Green and Colorado Rivers, Grand and San Juan Counties, Utah: U. S. Geol. Survey Bull. 908, 1940 [1941].

8. Dane, C. H., Geology of the Salt Valley anticline and adjacent areas, Grand County, Utah: U. S. Geol. Survey Bull. 863, 1935.

9. Fisher, D. J., The Book Cliffs coal field in Emery and Grand Counties, Utah: U. S. Geol. Survey Bull. 852, 1936.

10. Gilluly, James, Geology and oil and gas prospects of part of the San Rafael Swell, Utah; U. S. Geol. Survey Bull. 806-C, 1929.

11. Lupton, C. T., Geology and coal resources of Castle Valley in Carbon, Emery, and Sevier Counties, Utah: U. S. Geol. Survey Bull. 628, 1916.

12. Spieker, E. M., The Wasatch Plateau coal field, Utah: U. S. Geol. Survey Bull. 819, 1931.

13. Clark, F. R., Economic geology of the Castlegate, Wellington, and Sunnyside quadrangles, Carbon County, Utah: U. S. Geol. Survey Bull. 793, 1928. 


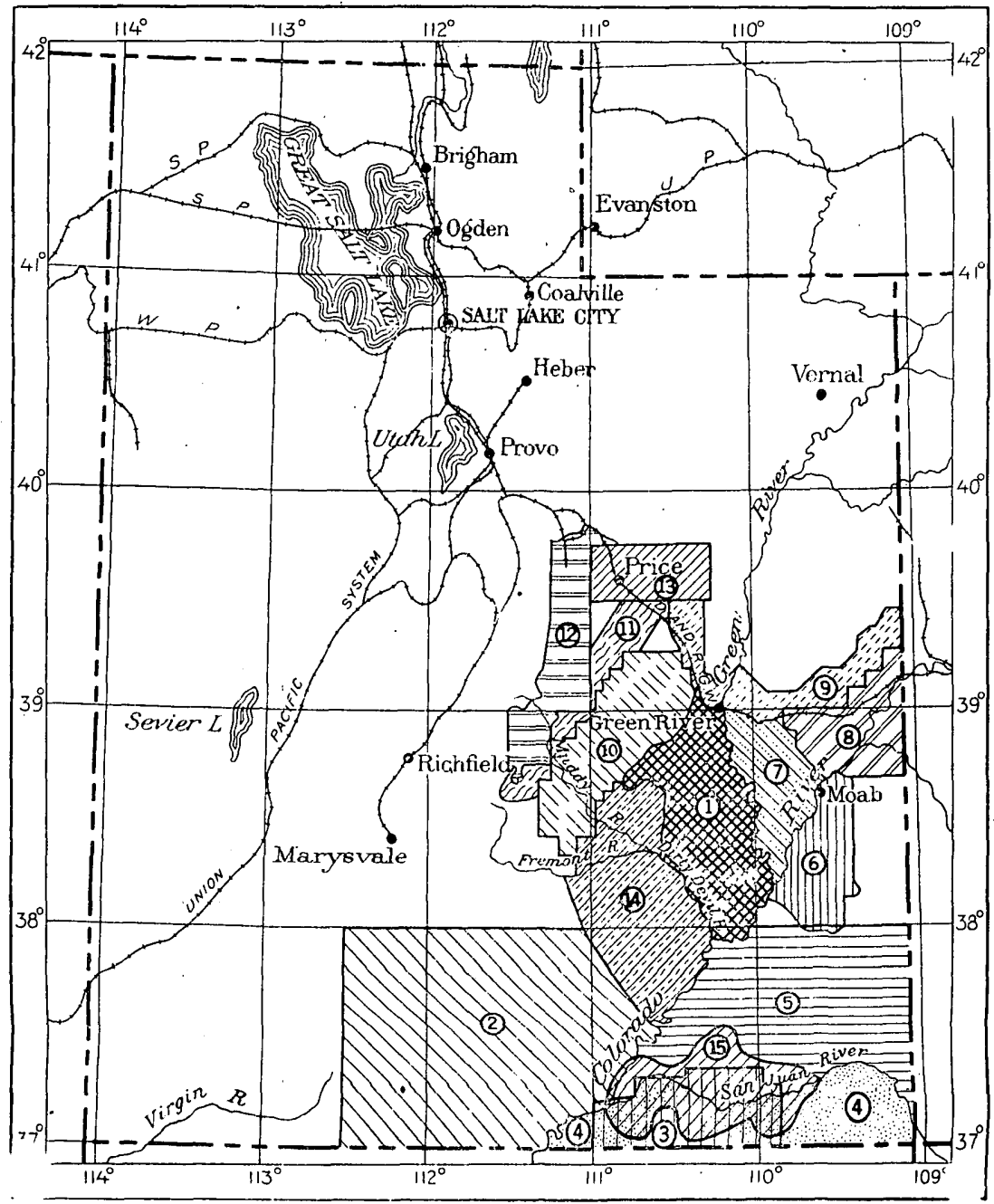

FIGURE 1.-Index map of Utah showing location of the Green River Desert-Cataract Canyon region and its relation to neighboring areas described in other reports. For a complete list of the reports see pages $20-21$.

14. Hunt, C. B., Geology and geography of the Henry Mountains structural basin (in preparation).

15. Miser, H. D., The San Juan Canyon, southeastern Utah, a geographic and hydrographic reconnaissance: U. S. Geol. Survey Water-Supply Paper 538, 1924; Geologic structure of San Juan Canyon and adjacent country, Utah: U. S. Geol. Survey, Bull. 751-D, 1925.

\section{PURPOSE AND SCOPE OF REPORT}

It is the purpose of this report to describe the geologic features of a large area in which there has been sporadic interest in the possible occurrence of oil and gas. The field work was undertaken to determine stratigraphic relationships and to map the geologic 
structure, primarily to obtain data necessary for the administration of the laws pertaining to the development and utilization of the public lands. The investigation also has provided data that contribute to the knowledge of the regional geology, and it thereby aids in the evaluation of the oil possibilities of southeastern Utah.

\section{FIELD WORK}

Field work on which this report is based was begun in June 1930 and continued until October 1930. It was resumed in June 1931 and completed in October 1931. A. J. Eardley, M. M. Knechtel, L. G. Henbest, and H. D. Curry acted as geologic assistants in 1930, and D. A. Andrews, R. L. Miller, and L. S. Gardner in 1931. Although the work was done under the direct supervision of the writer, most of the map of the area is a composite of the work of the geologic assistants. Because of the checkerboard pattern and the interdependance of the work of different individuals, it is not practicable to indicate the portions of the area for which they deserve credit.

The mapping of geology, drainage, and culture and the determination of altitudes was done almost entirely by triangulation with a telescopic alidade and plane table. A triangulation net was established from a measured base line, and this was checked at several places by measurements between primary points. Closely spaced locations to control sketching and to determine altitudes were made by the three-point method or by intersections from two or more points. The position of the land lines established by the General Land Office was determined by locating many of the iron pipes or stones marking the land corners. The altitudes determined on known geologic horizons and used to construct the structure contour map represent, within certain limits of error, actual height above sea level. The altitudes were determined by vertical-angle measurement from Coast and Geodetic Survey bench marks, which have been established at intervals along the road from the town of Green River to Hanksville. South of the San Rafael River the line of bench marks follows an old road, now little used, that is west of the main road. The location of several of the bench marks is shown on the map. (See pl. 1.) Stadia traverses were used in a few small areas to supplement the mapping by triangulation. The field work along the Green and Colorado Rivers was facilitated by the use of published maps of the Geological Survey showing the topography in narrow belts on each side of the river. ${ }^{1}$ Automobiles were used to transport supplies to a

\footnotetext{
1 Profile surveys in the Colorado River Basin in Wyoming, Utah, Colorado, and New Mexico: U. S. Geol. Survey Water-Supply Paper 396, 1917; Plan and profile of Colorado River, from Lees Ferryy, Ariz., to mouth of Green River, Utah, 1922.
} 
few main camps but the more inaccessible parts of the area were mapped from camps established by transporting camp equipment and supplies on pack animals.

\section{ACKNOWLEDGMENTS}

The writer is indebted to his field assistants, Messrs. Andrews, Curry, Eardley, Gardner, Henbest, Knechtel, and Miller for their able and conscientious cooperation, and to Messrs. Andrews and Knechtel for aid in the office. To A. C. Graves, C. R. Hanks, L. J. Christensen, and Marshall Cowsert, camp men, the writer wishes to express his appreciation for their industry and invaluable assistance during the field work. The writer also wishes to express his appreciation to many residents of the area who offered cordial cooperation and generous assistance that facilitated the progress of the field work. The investigation was carried on under the supervision of $H$. D. Miser, who has made many helpful suggestions during the field and office work.

\section{GEOGRAPHY}

\section{SURFACE FEATURES}

The Green River Desert-Cataract Canyon region is part of the Colorado Plateau, which includes a large area in southeastern Utah, northern Arizona, northwestern New Mexico, and southwestern Colorado. Plateaus, mesas, cliffs, and canyons are typical of the surface features of the Colorado Plateau.

The southern part of the Green River Desert-Cataract Canyon region is intricately dissected by numerous deep canyons, and the land surface rises in several huge steps from the Colorado and Dirty Devil Rivers to an upland surface of moderate relief that forms the interstream divides. Toward the north the upland surface gradually decreases in altitude and is less dissected by canyons; in the extreme northern part of the area it merges with a lowland that extends north of the area to the foot of the Book Cliffs. The highland formed by the San Rafael Swell in the northwestern part of the area rises abruptly above the adjoining Green River Desert.

The total relief is about 3,700 feet, the altitude ranging from about 3,460 feet on the Colorado River at the mouth of the Dirty Devil River to 7,139 feet on Lands End Butte, a low isolated butte on the upland surface about 20 miles northeast of the junction of those rivers. The surface altitude in general is about 4,100 feet at the town of Green River on the lowland at the north boundary of the area. The crest of the San Rafael Swell has a maximum altitude of about 7,000 feet and is 2,000 to 2,500 feet above the adjoining Green River Desert, 8 to 10 miles to the east. 
At the east boundary of the area the Green River flows through an open valley near the town of Green River, but below the town a few miles it is slightly entrenched, and the canyon deepens rapidly toward the south. Below the mouth of the San Rafael River, the Green River enters Labyrinth Canyon (pl. 15) through which it follows a circuitous route; at the Bowknot, the river follows a course more than 10 miles long to reach a point only 1 mile distant from the starting point. Near its upper end Labyrinth Canyon is only a few hundred yards wide and has low vertical walls, but near its lower end in the vicinity of the Emery-Wayne County line the canyon is nearly a mile wide and is more than 1,000 feet deep. A few miles south of the county line the canyon widens, but the river enters a narrow, inner, precipitous-walled gorge, which deepens toward the south to form Stillwater Canyon; this canyon is about 1,300 feet deep at the mouth of Green River (pl. 6, A). The Colorado River, below the mouth of the Green, enters Cataract Canyon (pls. $4, A, 5, A, B$ ), the average width of which.does not greatly exceed half a mile; it reaches a maximum depth of about 2,100 feet near Waterhole and Clearwater Canyons, but the depth decreases to less than a hundred feet at the mouth of the Dirty Devil River.

A platform or bench adjacent to the rim of Cataract Canyon and the lower part of Stillwater Canyon is about 7 miles wide opposite the junction of the Green and Colorado Rivers but decreases in width southwestward to about 1 mile at the south boundary of the area. This platform is dissected by numerous canyons tributary to the Green and Colorado Rivers, and its surface is marked by buttes, rounded domes, and several tall slender spires like Standing Rock (pl. 11, A) and Candlestick Spire; locally it is very rugged and picturesque (pls. 6, $A, B, 9, A$.) At the inner edge of the platform the surface rises in cliffs 100 to 400 feet high. The line of cliffs has a very irregular pattern with numerous indentations along stream courses. The cliffs are capped by a white sandstone-the "White Rim" of the local inhabitants. The northern extension of the White Rim forms the rim rock in the upper part of Stillwater Canyon. A platform above the White Rim merges throughout much of its extent with an area of "badland" slopes that extends to the next higher rim, but locally the platform at the top of the White Rim is not developed, and the white sandstone occurs in the middle of a steep slope or cliff. (See pl. 10, A, B.) The broad platform and badland slopes above the White Rim are well developed on the point between the Colorado and Dirty Devil Rivers and also on the west side of Stillwater Canyon. (See pls. 11, C, 12, B.)

Another rim rock, commonly known as the "Black Rim," is 300 
to 400 feet above the White Rim. It forms a bench that is narrow but distinct through most of its extent from a point on the Dirty Devil River, 20 miles above its mouth, to the lower end of Labyrinth Canyon, and locally it widens to a mile or more; it is best developed in the vicinity of Elaterite Basin and the head of Horse Canyon. (See pl. 10, A.)

Steep slopes rise from the Black Rim bench to the foot of a vertical cliff 300 to 400 feet high known as the "Red Rim." This cliff is the most conspicuous topographic feature in the area; it forms the rim of Labyrinth Canyon, and in the southern part of the area it bounds the remnants of the upland surface. The summit of South Block, the southernmost remnant of the upland surface, is about 3,300 feet above the Colorado River at the mouth of the Dirty Devil.

The Green River Desert, extending from the canyon lands in Wayne County to the northern boundary of the area, includes a variety of surface features. Areas covered by dune sand are interspersed with bare-rock surfaces, badlands, and broad soilcovered valleys. Broad areas of low relief are commonly bordered by cliffs 100 feet or more high; and large and small mesas, rounded domes or sharp spires of bare rock, and shallow canyons are common surface features. The lowland in the vicinity of the town of Green River is a desolate, nearly barren area of wide shallow valleys, low isolated hills and knolls, and long low hogbacks.

The San Rafael Swell rises abruptly above the Green River Desert and its southeast flank is marked by a sawtooth ridge known as the "Reef." (See pl. 16.) At the foot of its outer slope the Reef merges with the desert surface but the inner face is a cliff that overlooks a depression parallel to it. From this depression the surface rises in a smooth arc, convex upward, to the crest of the swell. The domed crest of the swell is dotted with a great many low mesas or rounded knolls. Several streams that head near the crest of the dome have cut deep canyons into its flanks and through the bordering Reef; the San Rafael River, which heads in the Wasatch Plateau west of the San Rafael Swell, has cut a canyon across the swell.

Much of the southern part of the Green River Desert-Cataract Canyon region has strikingly beautiful scenic effects resulting from the erosion of rocks of various colors and differing degrees of resistance to erosion. Deep narrow canyons, broad grassy flats bounded by nearly vertical walls, small alcoved canyons, wide platforms surmounted by buttes, mesas, and high spires, and high unscalable cliffs horizontally banded with different colors are features of this landscape. The vast panoramas observed through 
the clear air of this semiarid region from vantage points on the rim of the upland surface and the more restricted views from points on the rims of lower cliffs or from the summits of canyon walls are equaled at few places in the country. The view of Cataract Canyon from many places on the canyon rim is especially impressive, as numerous rapids can be seen at the bottom of the deep narrow gorge, and the roar from the rapids is clearly audible. Unfortunately, the region is far from the usual routes of travel and is in part relatively inaccessible.

\section{DRAINAGE AND WATER SUPPLY}

The Colorado River, which is the master stream in the drainage of the Colorado Plateau, and which forms the southeast boundary of the area, is a perennial stream. Between October 1929 and September 1930 the stream flow in the river below the mouth of the Green River ranged from a minimum of about 2,000 secondfeet in January to a maximum of about 47,000 second-feet during the spring runoff in June. ${ }^{2}$ The river flows in a deep narrow canyon and has a steep gradient with numerous rapids; the altitude of the river surface decreases from 3,880 feet at the mouth of the Green River to 3,460 feet at the mouth of the Dirty Devil River, which is at the average rate of nearly 9 feet per mile for a distance of $491 / 2$ miles. Although the river normally contains an abundant water supply, the confining canyon walls permit access to the river at very few localities.

The Green River, which forms the eastern boundary of the area between its junction with the Colorado River and the town of Green River, is the largest tributary of the Colorado River. It is a perennial stream, which heads in the mountains of southwestern Wyoming and northwestern Colorado. The stream flow as recorded in 1929-30 by measurements at Green River, Utah, ranged from a minimum of 685 second-feet in December to a maximum of 22,500 second-feet in June. ${ }^{3}$ Some water is diverted from the Green River above the mouth of the San Rafael River for irrigation, but below the mouth of the San Rafael River it enters a canyon, and the water is used only by a few head of stock that graze in the bottom land along the river. Access to the river from the upland plateau is barred by the canyon walls, and the water cannot be reached by stock that graze on the plateau,

\footnotetext{
2 No gaging stations are maintained on the Colorado River within the area, and the figures for stream flow are based upon measurements of the Colorado River near Cisco, Utah, and Lees Ferry, Ariz., and of its larger tributaries, the Green River at Green River, Utah, and the San Juan River at Bluff, Utah. Surface water supply of the United States, 1930, Part 9, Colorado River Basin: U. S. Geol. Survey Water-Supply Paper 704, 1943.

${ }^{3}$ Surface water supply of the United States, 1930, pt. 9 Colorado River Basin: U. S. Geol. Survey Water-Supply Paper 704, p. 31, 1932.
} 
except at a few places where trails have been built. The river follows a meandering course; the distance along the river from the town of Green River to its mouth is $\mathbf{1 1 7}$ miles, or more than twice the air-line distance of about 56 miles. The altitude of the river surface decreases from about 4,070 feet at Green River to 3,880 feet at its mouth, with an average gradient of about 1.6 feet a mile for the total distance.

The San Rafael and Dirty Devil Rivers are the principal perennial streams tributary to the west side of the Green and Colorado Rivers within the area. The San Rafael River rises in the highlands of the Wasatch Plateau west of the San Rafael Swell. In freshet stages it is a large swift-flowing stream 10 feet or more in depth, but during the late summer months the depth of the water at many places is a foot or less, and during occasional prolonged droughts the river carries no water in the part of its course east of the swell. At normal stages of the river the water has a high mineral content and cannot be used for domestic purposes, but it is used to water stock and to irrigate small areas of bottom land. The Dirty Devil River, which heads in the highlands of the Wasatch, Fish Lake, and Awapa Plateaus, many miles west of the area, is similar to the San Rafael River. After hard rains and during the spring runoff it is a deep swift flowing stream; but in normal stages it is a shallow stream, and occasionally its channel contains no water. For many years, the town of Hanksville obtained its water supply from the Dirty Devil River by diverting water to cisterns during the spring flood, but in ordinary stages of the river the water is too alkaline for domestic use. At several places west of the area, bottom land is irrigated with river water, but within the area mapped, where the river flows through a deep canyon, the water is used only by stock.

The Dirty Devil River, at its mouth, was named by Powell ${ }^{4}$ in 1869 , and the name has long been applied to the part of the river below the town of Hanksville.

Except for the occasional floods that occur in all streams in the region that lie in the paths of rainstorms, the only other running water is found in channels fed by springs, and in all those the water flows only a short distance before it sinks into the sand and gravel in the bed of the streams.

In this region the principal water supply that can be used for domestic purposes and to support the grazing industry is obtained from a large number of springs. Most of the springs flow at a

\footnotetext{
4 Powell, J. W., Exploration of the Colorado River of the West and its tributaries, 1869-72. p. 67, Smithsonian Inst., 1875.
} 
rate of less than a gallon a minute, but a few springs have a somewhat larger yield. During the summer months, and particularly during prolonged droughts, the yield from many of the springs decreases, and some of them become dry. At some springs the water is gathered in covered trenches and conducted by pipes to troughs or tanks, to permit effective utilization, but at many springs there are no improvements and where the water does not collect in natural depressions in the rock it quickly sinks below the surface and is of little use to stock.

Springs occur principally in the Moenkopi, Kayenta, Navajo, Carmel, and Entrada formations, but there are a few springs in the Shinarump and Morrison formations. The springs from the Kayenta, Navajo, and Entrada formations supply excellent water and some of the water issuing from the Carmel formation, particularly from the basal part, is of good quality. The water from many of the Carmel and the Moenkopi springs contains a large amount of dissolved calcium sulfate and is not suitable for domestic use, although it is used by stock. Practically all the springs in the Entrada sandstone yield only small amounts of water.

Although there are numerous springs in the region they may be many miles apart and travelers in the region should inform themselves concerning the location of water supplies. The locations of the springs visited by members of our party are shown on plate 1 but doubtless there are a few other springs in the region, particularly in the beds of some of the canyons. The table that follows lists the springs, their location, and the waterbearing horizons and gives a general idea concerning the flow from the springs and the quality of water. The springs designated as "small" have an estimated yield of less than 1 gallon a minute and those listed as "relatively large" yield possibly 5 to 10 gallons a minute. The quality of the water is indicated as "good" if the water was found to be reasonably satisfactory for camp use. Designations of "poor", "alkaline", and the like, are based upon our own observations or information obtained from local residents.

Accumulations of rain water in natural depressions in the rocks, commonly known as tanks, or in small artificial reservoirs are also important sources of water in the region. During rainstorms water collects in innumerable depressions on bare-rock surfaces. Such accumulations supplement the supply of spring water, and in large parts of the area they afford a temporary supply of excellent water where no other water can be obtained. Those tanks that are accessible to stock permit grazing over a much wider area for short periods following rainstorms than other types of water supply ordinarily permit. 


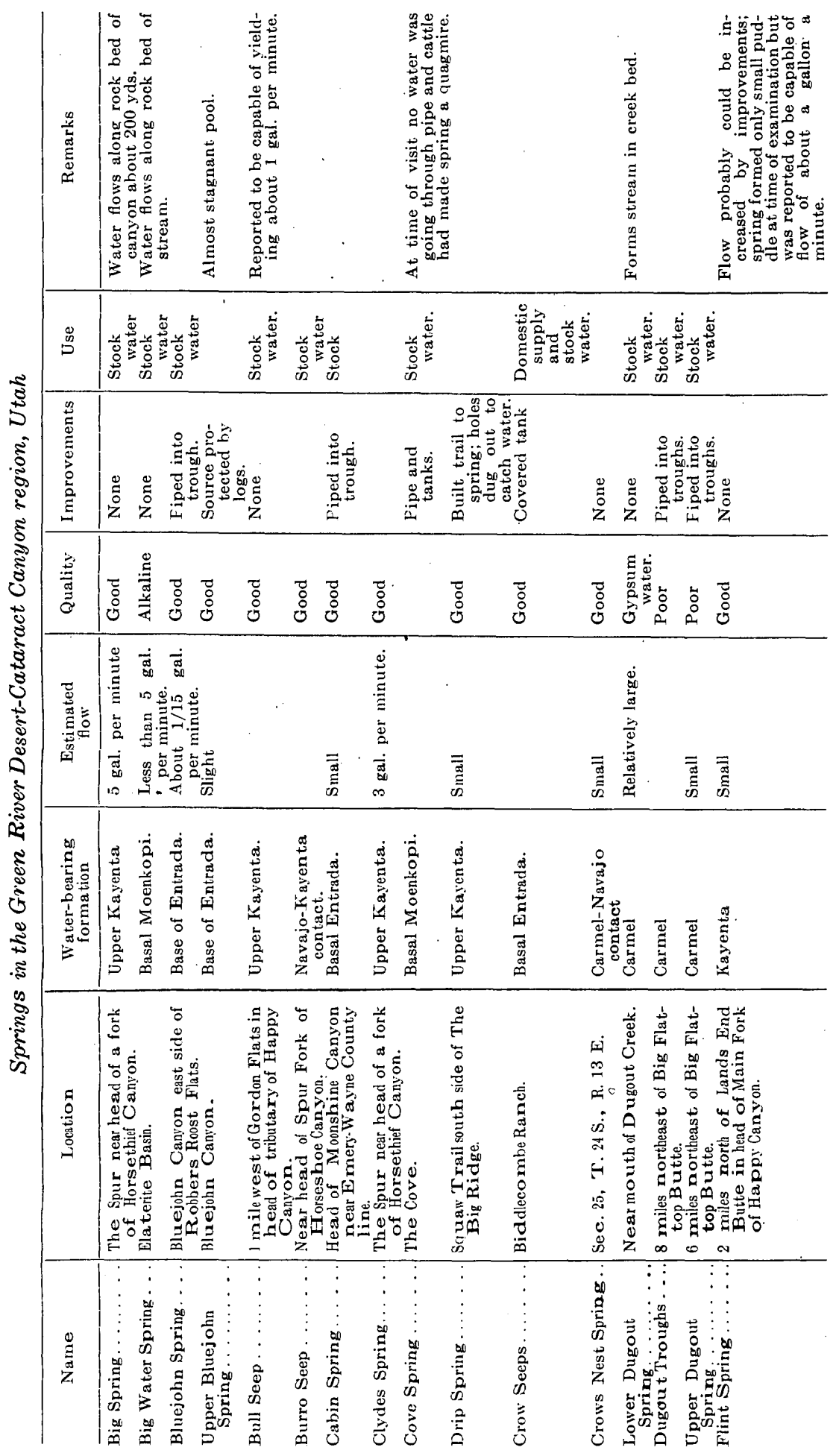




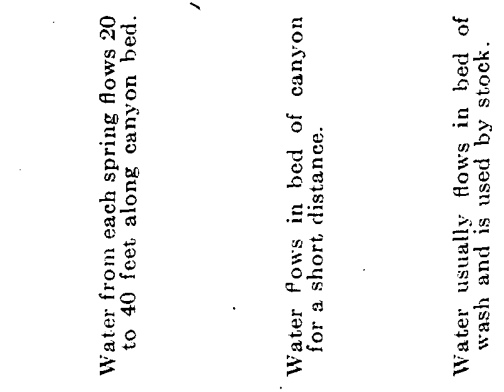

高竞

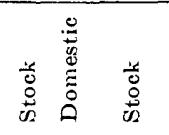

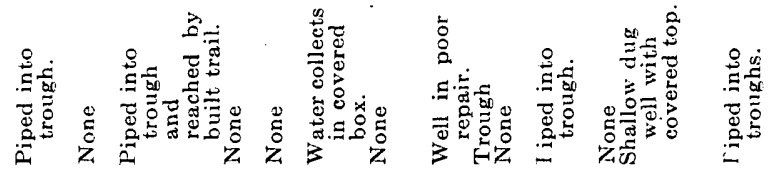

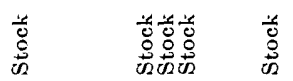

11

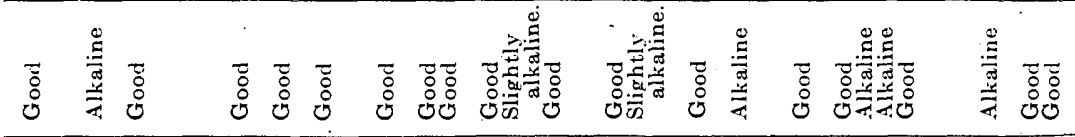

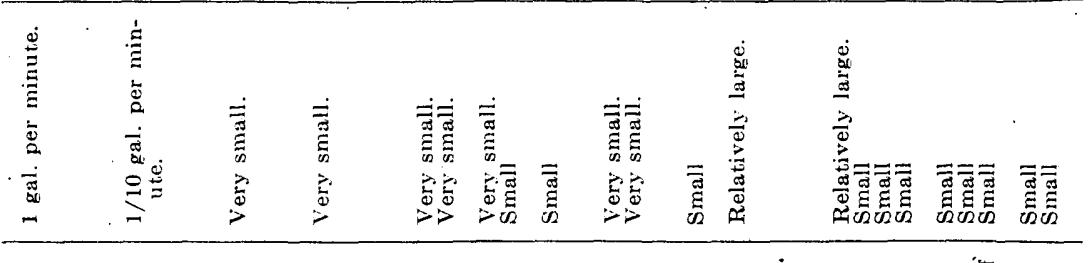

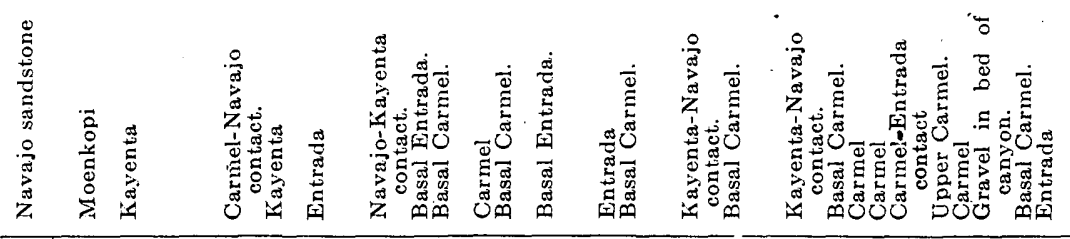

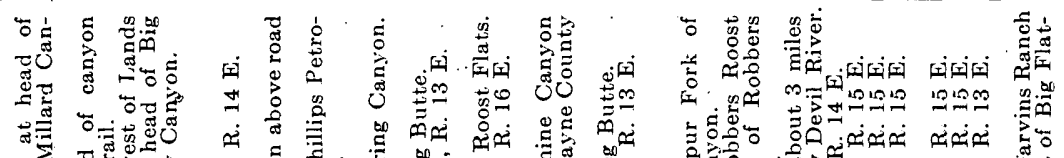

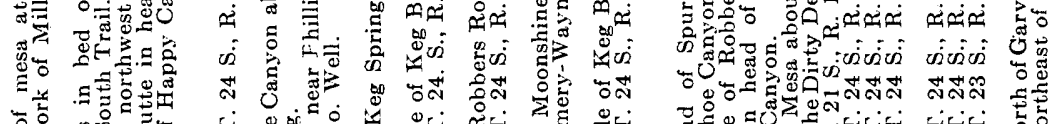

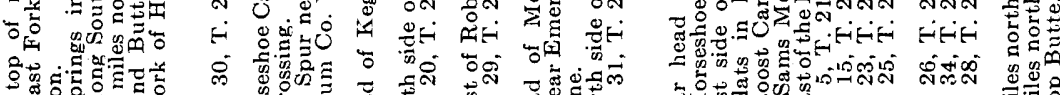

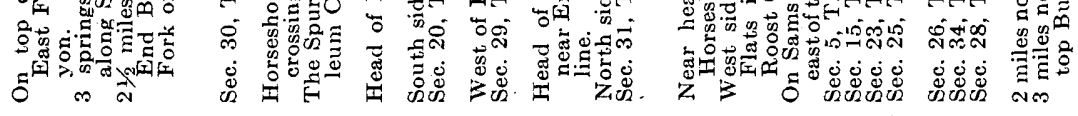

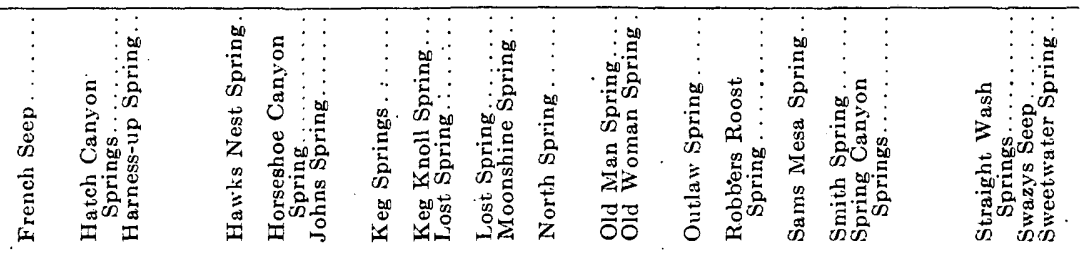




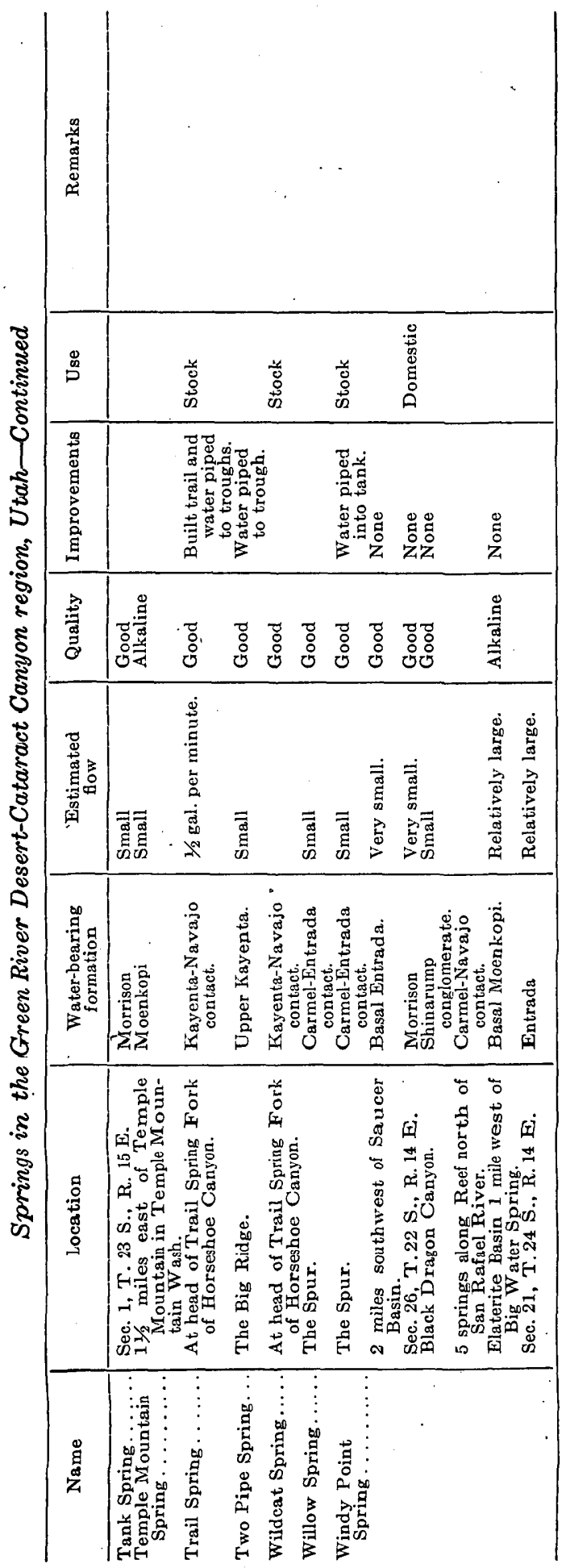


Tanks may be divided into two general types: (1) shallow depressions on rock surfaces for the most part independent of stream channels and (2) deep pot holes usually located in stream channels, especially in canyon bottoms. Tanks of the first type are by far the most abundant but are of slight importance, as they contain small quantities of water and become dry in a few hours, or at most a few days after the rainstorm has passed. Those of the second type contain the important supplies of water, as they may be tens of feet in diameter and 10 feet or more in depth; such tanks when full contain thousands of gallons of water. The pot-hole type of tank presents a smaller water surface to the air in proportion to the amount of water it contains than the shallow depressions of the first type, and many of the pot holes are located in deep narrow canyons where they are sheltered from the direct rays of the sun, so that the loss of water by evaporation is minimized. Some of the pot-hole tanks are accessible to stock, which may cause water in large tanks to disappear within a few weeks after it accumulates. Other tanks, which are inaccessible to stock, may contain large quantities of water for long periods, even extending through protracted droughts, and hence constitute a practically permanent though limited supply of excellent water. Experienced travelers in this region place great reliance upon these semipermanent accumulations of water, but as no stock trails lead to them the inexperienced traveler may have great difficulty in locating these vital water supplies. The location of many of the larger tanks is shown on plate 1.

A well drilled by the Texas Production Co. near the EmeryWayne County line about a mile southeast of the Big Flattop Butte encountered artesian water at several horizons. (See log of well, p. 115). Water is pumped from this well for use in watering stock. Artesian water also is pumped from a drilled well at Garvin's Ranch, but the water is of poor quality and is used only for stock.

\section{CLIMATE AND VEGETATION}

The climate of the Green River Desert-Cataract Canyon region is semiarid to arid. Recording stations of the United States Weather Bureau at Green River (altitude, 4,087 feet) and Hanksville (altitude, 4,200 feet) about 20 miles southwest.of Garvin's Ranch, show the average annual rainfall over a period of more than 20 years to be 6.24 inches and 5.41 inches, respectively. Both recording stations are in areas of relatively low altitude. There is somewhat greater precipitation in the higher parts of the area, such as the crest of the San Rafael Swell and the upland surface in the southern part of the area, but no measurements have been 
made by the Weather Bureau there. The greater rainiall in the higher areas is indicated by the presence of piñon pines and other forms of vegetation not found in the lowlands. The average distribution of rainfall by months is shown in the table. Slightly more rain falls during the summer months than at other times of the year, and the summer rains usually occur as torrential thunderstorms, which move in a relatively narrow path. These hard showers may last only a few minutes, but the water drains quickly from bare-rock surfaces and causes floods in the drainage channels. Such floods may cause considerable damage to roads and other improvements. Snowfall in the region is not great enough to interfere seriously with winter activities. Observations by the United States Weather Bureau for the year 1933 recorded 12.5 inches of snow at Hanksville and 9.4 inches at Green River. The temperature for the year 1933 ranged from $-32^{\circ} \mathrm{F}$. to $108^{\circ} \mathrm{F}$. at Green River and from $-18^{\circ} \mathrm{F}$. to $110^{\circ} \mathrm{F}$. at Hanksville.

The vegetation of the Green River Desert-Cataract Canyon region is typical of that found on the Colorado Plateau. The lowlands are devoid of trees except for groves of cottonwoods along streams, occasional cottonwoods at springs, and the orchard and shade trees in the town of Green River. As the surface altitude increases toward the south, juniper is found on isolated mesas and with further increase in altitude it is found rather abundantly. In the higher parts of the region piñon pine is abundant and a few yellow pines are present on the San Rafael Swell. Rabbitbrush, greasewood, and sagebrush are common in the region, particularly in bottom lands, and blackbrush is common on higher ground. Many plants of desert types, such as shadscale, yucca, and several varieties of cactus are found throughout the region. Several varieties of grass are present, but the total pasturage is not great.

\section{POPULATION}

The population of the Green River Desert-Cataract Canyon region is concentrated in the vicinity of the town of Green River. The 1940 census $^{5}$ reported the population of Green River as 470. Except for the inhabitants of the town of Green River and vicinity, the population density is approximately 1 person to 100 square miles; only about 25 people live beyond the immediate vicinity of the town, and these people live at three ranches on the San Rafael River and at cattle camps at Garvin's Ranch, on The Spur, at North Spring, at the Biddlecome Ranch, and in the canyon of Green River. Hundreds of square miles in the region

B Sixteenth census of the United States, 1940, Pöpulation, vol. 1, p. 1082, 1942. 


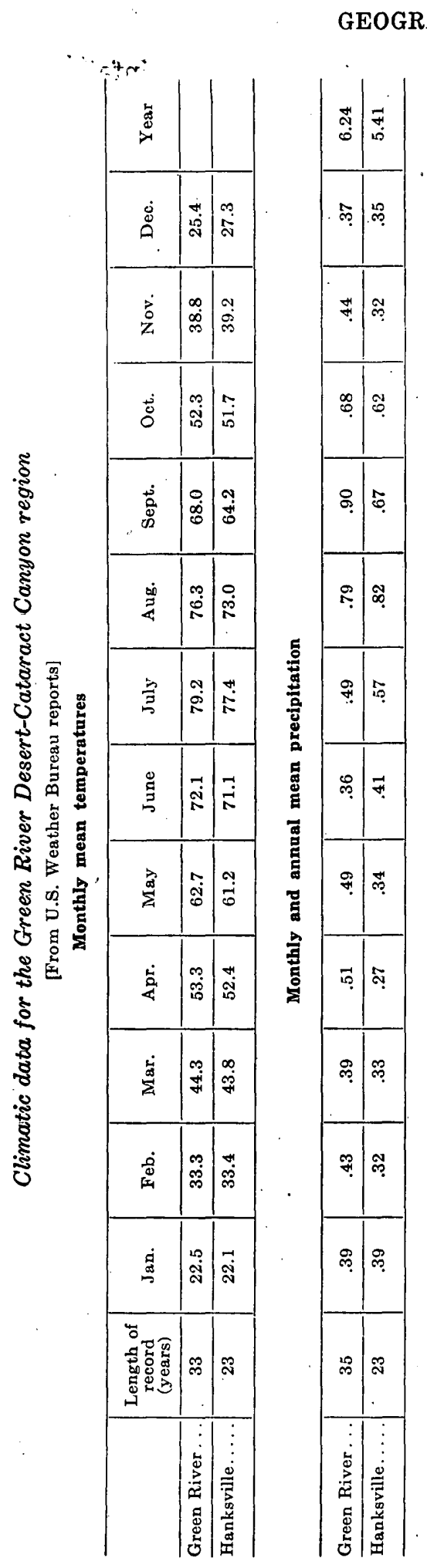


have no permanent inhabitants and are visited only by people tending their stock.

Farming and stock raising are the principal industries in the region. Farming activities are confined to irrigated bottom lands in the vicinity of the town of Green River and along the San Rafael River. Important products of the farms near Green River are cantaloupes, watermelons, apples, and tomatoes, which are shipped to distant markets, but dairy products, corn, hay, and miscellaneous fruits and vegetables also are produced. Forage crops are the principal products of the farms along the San Rafael River and are used for winter feeding of stock. Two or three thousand head of cattle graze in the area throughout the year. The area also is an important winter range for thousands of sheep, which graze in the high country of eastern Utah and western Colorado during the summer months. A few horses are raised for local needs, and large bands of wild horses roam the region.

\section{ACCESSIBILITY AND ROUTES OF TRAVEL}

The Green River Desert-Cataract Canyon region can be reached by the main line of the Denver \& Rio Grande Western Railroad and by United States Highway 50, which follow the north boundary of the region. The highway is graded and surfaced with oiled gravel. Several short dirt roads lead west and southwest from the highway toward the northern part of the San Rafael Reef. The principal road in the region leads southwest from the town of Green River. It branches three miles south of town; the western branch leads to Hanksville which is located on the Dirty Devil River, about 20 miles southwest of Garvin's Ranch, and the eastern branch leads to the upland between the Dirty Devil and Colorado Rivers in the southern part of the area. The Hanksville road, State Road 24, is not graded or surfaced but is passable all year except for short periods in wet weather. The eastern branch leading to the upland is a poor road for automobiles because of rocks and sand. From Hanksville a graded road leads to Richfield, Utah, located on a branch line of the Denver \& Rio Grande Western Railroad about 125 miles to the west. A few branching roads lead to parts of the area more or less remote from the main roads mentioned above. Dirt roads branching from the Hanksville road lead upstream and downstream along the San Rafael River. The eastern road leading south from Green River branches in Antelope Valley; one branch crosses Horseshoe Canyon by means of a steep rock-cut dugway and leads to the well drilled by the Phillips Petroleum Co. on the Spur; another branch leads west past the Flattop Buttes to 
Hanksville but is so sandy west of the Buttes that it is seldom used.

The roads provide direct access to a relatively small part of the Green River Desert-Cataract Canyon region and most of the region can be reached only on foot or by horseback. Cliffs and canyons impede direct travel and at numerous places a circuitous route of many miles must be traveled to reach a destination only a fraction of a mile distant. Trails have been built across the cliffs at many places and a knowledge of these trails is almost essential to a person attempting to cross the region by horseback. The principal trails are shown on plate 1 .

Little use is made of boats for transportation on the Green or Colorado Rivers. Shallow-draft powerboats have been used intermittently for many years on the Green River between its mouth and the town of Green River but the river can be navigated with difficulty because of shallow water, sand bars, and occasional rapids. Several exploring expeditions have made the hazardous trip by boat through Cataract Canyon but the boats used by these expeditions have been especially designed for use in the swift-flowing turbulent water of the numerous rapids; no one has made a trip upstream by boat through this section of the Colorado River Canyon. The Dirty Devil and San Rafael Rivers normally are too shallow to permit boat travel.

\section{PREVIOUS PUBLICATIONS}

Some features of the geology of the Green River Desert-Cataract Canyon region were described in the reports of early exploring expeditions. References to these reports are listed in the bibliography given below.

Gunnison, in 1853, leading an expedition that followed approximately the northern boundary of the area, made brief notes concerning the geology along the route. Powell explored the canyons of the Green and Colorado Rivers by boat in 1869, and while on a second expedition in 1871 he described the general features of the geology along the rivers and in the adjoining territory. Many of the geographic names now in use were first applied by him. Reports by Gilbert, Howell, and Dutton, although they do not apply specifically to the Green River Desert-Cataract Canyon region, outline the major features of the geology of southeastern Utah.

Many geologists have visited this area and adjacent regions, and reference has been made in numerous publications to special features of the geology. The geology and coal deposits of the Book Cliffs were mapped by Richardson and Fisher. Lupton briefly 
described the geology of the San Rafael Swell and also described the oil and gas possibilities near Green River. Emery published a brief description of the sedimentary rocks that crop out in the Green River Desert. Pardee described an occurrence of manganese east of Green River.

Several geologists have published reports on the regional stratigraphy or structure of southeastern Utah, which apply also to the Green River Desert-Cataract Canyon region.

In addition to the report by Fisher on the Book Cliffs coal field, which adjoins the area on the north, published reports, or reports in preparation, describe the geology of specific adjoining areas. The area on the east, extending from the Denver \& Rio Grande Western Railroad to the mouth of the Green River, has been described by McKnight.

Baker and Gregory have described the geology of the region southeast of Cataract Canyon between the mouths of the Green and the Dirty Devil Rivers. Gilluly has mapped the geology of the part of the San Rafael Swell northwest of the area. Hunt has mapped the geology of the region southwest of the Dirty Devil River extending from the south end of the San Rafael Swell to the Colorado River, including the Henry Mountains, and adjoining the Green River Desert-Cataract Canyon region on the west.

Baker, A. A., Geology and oil possibilities of the Moab district, Grand and San Juan Counties, Utah: U. S. Geol. Survey Bull. 841, 1933.

Geologic structure of southeastern Utah: Am. Assoc. Petroleum Geologists Bull., vol. 19, pp. 1472-1507, 1935.

Baker, A. A., Dane, C. H., and Reeside, J. B., Jr., Paradox formation of eastern Utah and western Colorado: Am. Assoc. Petroleum Geologists Bull., vol. 17, pp. 963-980, 1933.

_- Correlation of the Jurassic formations of parts of Utah, Arizona, New Mexico, and Colorado: U. S. Geol. Survey Prof. Paper 183, 1936.

Baker, A. A., and Reeside, J. B., Jr., Correlation of the Permian of southern Utah, northern Arizona, northwestern New Mexico, and southwestern Colorado: Am. Assoc. Petroleum Geologists Bull., vol. 13, pp. 1413-1448, 1929.

Baker, A. A., and Williams, J. S., Permian in parts of Rocky Mountain and Colorado Plateau regions: Am. Assoc. Petroleum Geologists Bull., vol. 24, pp. 617-635, 1940.

Beckwith, E. G., Reports of explorations and surveys, to ascertain the most practicable and economical route for a railroad from the Mississippi River to the Pacific Ocean: 33d Cong., 2d sess., S. Ex. Doc. 78, vol. 2, pp. 61-63, 1855 .

Butler, B. S., and others. The ore deposits of Utah: U. S. Geol. Survey Prof. Paper 111, 1920.

Dake, C. L., The horizon of the marine Jurassic of Utah: Jour. Geology, vol. 27, pp. 634-646, 1919.

The pre-Moenkopi (pre-Permian?) unconformity of the Colorado Plateau: Jour. Geology, vol. 28, pp. 61-74, 1920. 
Dutton, C. E., Report on the geology of the High Plateaus of Utah: U. S. Geog. and Geol. Survey Rocky Mtn. Region, 1880.

The physical geology of the Grand Canyon district: U. S. Geol. Survey 2d Ann. Rept., pp. 49-166, 1882.

Tertiary history of the Grand Canyon district: U. S. Geol. Survey Mon. 2, 1882.

Emery, W. B., The Green River Desert section, Utah: Am. Jour. Sci., 4th ser., vol. 46, pp. 551-577, 1918.

Fisher, D. J., The Book Cliffs coal field in Emery and Grand Counties, Utah: U. S. Geol. Survey Bull. 852, 1936.

Forrester, J. B., A general survey of the Jurassic in southeastern Utah: Utah Acad. Sci. Trans., vol. 1, pp. 33-43, 1918.

Gilbert, G. K., Report on geology of portions of Nevada, Utah, California, and Arizona, U. S. Geog. and Geol. Surveys W. 100th Mer. Rept., vol. 3, pp. 17-187, 1875.

Report on the geology of the Henry Mountains, U. S. Geog. and Geol. Survey Rocky Mtn. Region, 1877.

Gilluly, James, Geology and oil and gas prospects of part of the San Rafael Swell, Utah: U. S. Geol. Survey Bull. 806, pp. 69-130, 1929.

Gilluly, James, and Reeside, J. B., Jr., Sedimentary rocks of the San Rafael Swell and some adjacent areas in eastern Utah: U. S. Geol. Survey Prof. Paper 150, pp. 61-110, 1928.

Gregory, H. E., The San Juan country, a geographic and geologic reconnaissance of southeastern Utah: U. S. Geol. Survey Prof: Paper 188, 1938.

Howell, E. E., Geology of portions of Utah, Nevada, Arizona, and New Mexico, U. S. Geog. and Geol. Surveys W. 100th Mer. Rept. vol. 3, pp. 231-301, 1875.

Hunt, C. B., Geology of the Henry Mountains structural basin: U. S. Geol. Survey report (in preparation).

Lee, W. T., Early Mesozoic physiography of the southern Rocky Mountains: Smithsonian Misc. Coll., vol. 69, no. 4, 1918.

Longwell, C. R., and others, Rock formations in the Colorado Plateau of southeastern Utah and northern Arizona: U. S. Geol. Survey Prof. Paper 132, pp. 1-23, 1925.

Lupton, C. T., Notes on the geology of the San Rafael Swell, Utah: Washington Acad. Sci. Jour., vol. 2, pp. 185-188, 1912.

Oil and gas near Green River, Grand County, Utah: U. S. Geol. Survey Bull. 541, pp. 115-133, 1914.

McKnight, E. T., Geology of area between Green and Colorado Rivers, Grand and San Juan Counties, Utah: U. S. Geol. Survey Bull. 908, 1940 [1941].

Pardee, J. T., Deposits of manganese ore in Montana, Utah, Oregon, and Washington: U. S. Geol. Survey Bull. 725, pp. 179-206, 1922.

Powell, J. W., Exploration of the Colorado River of the West and its tributaries, 1869-72, Smithsonian Inst., 1875.

Prommell, H. W. C., and Crum, H. E., Salt domes of Permian and Pennsylvanian age in southeastern Utah and their influence on oil accumulation: Am. Assoc. Petroleum Geologists Bull., vol. 11, pp. 373-393, 1927.

-Structural history of parts of southeastern Utah from interpretations of geologic sections: Am. Assoc. Petroleum Geologists Bull., vol. 11, pp. 809-820, 1927.

Richardson, G. B., Reconnaissance of the Book Cliffs coal field, between Grand River, Colo., and Sunnyside, Utah: U. S. Geol. Survey Bull. 371, 1909. 


\section{STRATIGRAPHY}

GENERAL FEATURES

The formations exposed in the Green River Desert-Cataract Canyon region have a total average thickness of about 6,500 feet. (See pl. 3.) The Paradox formation, which is present in isolated outcrops in Cataract Canyon, is tentatively assigned to the lower Pennsylvanian and is probably the oldest formation exposed ; sandstone and limestone exposed at two locations beneath the Coconino sandstone in the San Rafael Swell may be of Mississippian age but probably is younger than the Paradox. The youngest rocks, with the exception of surficial Tertiary (?) and Recent deposits, are in the lower part of "the Mancos shale of Upper Cretaceous age. Between the Pennsylvanian and the Upper Cretaceous are representatives of the Permian, Triassic, and Jurassic systems.

The rocks consist of interbedded marine and continental formations; the marine formations include the Pennsylvanian Paradox and Hermosa, the Permian Rico in part and the Kaibab, the Triassic Moenkopi in part, the Jurassic Carmel and Curtis and possibly the Entrada and Summerville in part, and the Upper Cretaceous Mancos. The formations of continental origin include several massive sandstones that are wholly or in part of eolian origin. These sandstones, which commonly form nearly vertical cliffs and control the development of the cliff and mesa topography typical of the region, include the Coconino, Cedar Mesa, White Rim, Wingate, Navajo, and Entrada sandstones. Limestone is abundant only in the lower part of the section both in the Pennsylvanian and in the Permian. The rocks between the top of the Pennsylvanian and the base of the Upper Cretaceous comprise the so-called red-bed series that is of widespread occurrence in the plateau region of Utah, Arizona, New Mexico, and Colorado. The red color is most conspicuous in the softer slope-forming formations, such as the red tongues of the Cutler, the Moenkopi, Chinle, Carmel, Summerville, and Morrison formations. The interbedded massive sandstones are in general buff to gray, but the Entrada sandstone is red over a large part of the area of its outcrop and there are bands of red in the Cedar Mesa sandstone member of the Cutler formation, particularly along the lower Green River.

The Paleozoic rocks crop out in the southern part of the region along the canyons of the Green and Colorado Rivers and their tributaries and in the San Rafael Swell. Northwestward from the Colorado River the lower Mesozoic formations crop out above the Paleozoic rocks in cliffs, steep slopes, and benches rising to the edge of the dissected upland surface, which is rimmed by the Jurassic (?) Wingate sandstone; and progressively younger rocks 
crop out toward the north on the upland surface. Along the flank of the San Rafael Swell the rocks between the top of the Paleozoic and the Jurassic Carmel formation dip steeply to the east and crop out in a narrow belt; the softer rocks form narrow strike valleys, and the more resistant rocks form serrated ridges.

Reports ${ }^{6}$ describing regional correlations of formations exposed in the Green River Desert-Cataract Canyon region, based upon detailed mapping of other areas in southeastern Utah and reconnaissance stratigraphic studies in adjacent areas, have been published. These reports describe the Paradox formation and the regional correlation of both the Permian and the Jurassic formations. The reader is referred to the reports for a more detailed discussion of these phases of the geology than is given in this report, particularly for correlations, discussion of nomenclature used by other writers, and discussion of the paleogeography during these periods. These topics are discussed in the present paper only insofar as they have special bearing on the local geology of the Green River Desert-Cataract Canyon region.

\section{CARBONIFEROUS SYSTEM}

\section{PENNSYIVANIAN SERIES}

\section{PARADOX FORMATION}

The Paradox formation, which includes the oldest exposed rocks, crops out in the Green River Desert-Cataract Canyon region only in the bottom of Cataract Canyon. Exposures observed by the writer at two localities on the east bank of the river (pl. 1) were not examined because of their inaccessibility; a relatively close view of the exposure at the head of Cataract Canyon was obtained from the west bank of the river at Spanish Bottom, but in general the location and configuration of the outcrops were determined by observations from the west rim of the canyon. Paige $e^{7}$ observed an outcrop of the formation (not shown on pl. 1) in the bottom of Cataract Canyon about 3 miles below the mouth of Red Lake Canyon and another outcrop in a side canyon (Gypsum Canyon) some distance east of the Colorado River but did not describe in detail the rocks exposed at those localities. Some information regarding

\footnotetext{
${ }^{6}$ Baker, A. A., Dane, C. H., and Reeside, J. B., Jr., Paradox formation of eastern Utah and western Colorado: Am. Assoc. Petroleum Geologists Bull., vol, 17, pp. 963-980, 1933; Correlation of the Jurassic formations of parts of Utah, Arizona, New Mexico, and Colorado: U. S. Geol. Survey Prof. Paper 183, 1936; Baker, A. A., and Reeside, J. B., Jr., Correlation of the Permian of southern Utah, northern Arizona, northwestern New Mexico, and southwestern Colorado: Am. Assoc. Petroleum Geologists Bull., vol. 13, pp. 1413-1448, 1929; Baker, A. A., and Williams, J. S., Permian in parts of Rocky Mountain and Colorado Plateau regions: Am. Assoc. Petroleum Geologists Bull., vol, 24, pp. 617-635, 1940.

${ }^{7}$ Paige, Sydney, Unpublished notes recorded while traversing Cataract Canyon by boat in 1921 as a member of a Geological Survey party engaged in examination of dam sites.
} 
the subsurface extent of the formation in the area has. been supplied by a few drilled wells.

Available information regarding the lithology, age, and regional distribution of the formation in southeastern Utah, which has been obtained from a few small isolated outcrops and numerous drilled wells, has been summarized in published papers ${ }^{8}$ to which the reader is referred for additional information.

The two outcrops observed by the writer in Cataract Canyon are at the mouths of tributary canyons and are roughly circular masses, with a maximum diameter of about half a mile, which rise to a maximum height of 200 to 300 feet above the river. (See pl. 4, $A, B$.) The only available information regarding the lithology of the formation at those outcrops is that the rocks are principally gypsum. However, the lithology is probably comparable to that at other small isolated exposures in southeastern Utah in Moab and Salt Valleys, about 25 miles east of the Green River, and at a few other localities farther east along the Salt Valley faulted fold.

At those localities, the Paradox formation consists predominantly of gypsum with some interbedded gray limestone, sandstone, and black and greenish shale. The bedding is normally thin and regular, but flowage movement in the gypsum has disrupted and contorted the bedding, and the limestone, sandstone, and shale are observed as discontinuous chunks of irregular size. Individual beds cannot be followed for more than a few feet. Samples of drill cuttings show that the formation at depth consists largely of salt and anhydrite with'subordinate limestone, shale, and sandstone. The well drilled by the Phillips Petroleum Co. on the Spur is the only well drilled in the Green River Desert-Cataract Canyon region that encountered the Paradox formation; it was drilled through about 700 feet of anhydrite that is believed to represent all the formation at that locality. No rocks that could be correlated with the Paradox formation were encountered in the wells drilled by the Standard Oil Co. near the axis of the San Rafael Swell.

At the outcrops in Cataract Canyon the plastic salt and gypsum of the Paradox formation have been extruded through openings caused by arching and rupturing of Hermosa rocks, so that normal stratigraphic relations are not evident. At all other outcrops of the formation in Utah and Colorado the Paradox formation also crops out as a result of rupture of the overlying rocks and it is brought into fault contact with rocks ranging in age from the Pennsylvanian Hermosa formation to the Cretaceous Mancos shale.

${ }^{8}$ Baker, A. A., Dane, C. H., Reeside, J. B., Jr., Paradox formation of eastern Utah and western Colorado: Am. Assoc. Petroleum Geologists Bull., vol. 17, pp. 963-980, 1933. Bass, N. W., Correlation of basal Permian and older rocks in southwestern Colorado, northwestern New Mexico, northeastern Arizona, and southeastern Utah: U. S. Geol. Survey, Oil and Gas Investigations, Preliminary chart 7, 1944. 
Numerous wells drilled in southeastern Utah where the rocks are undisturbed by faulting show that the Paradox formation normally underlies the Hermosa formation apparently with a gradational contact.

The base of the formation is not exposed anywhere and its relations to underlying rocks can only be inferred from knowledge of older rocks exposed at distant localities and from well logs. In the San Juan Mountains of Colorado the Hermosa formation rests upon the thin Molas formation, also of Pennsylvanian age, and the Molas rests upon an erosional unconformity cut on the underlying Leadville limestone, which is of lower Mississippian age. ${ }^{9}$ Conglomerate that crops out at two localities in Salt Valley, Utah, has lithology similar to conglomerate beds in the Molas formation and probably has an analogous stratigraphic position, but its relation to the Paradox formation is obscure because of complicated structure and incomplete exposures; the outcrops may represent isolated blocks of the underlying floor carried upward during the flowage movement of the plastic Paradox rocks. A well drilled on the Shafer dome in T. 27 S., R. 20 E., on the Colorado River is believed. to have reached the base of the Paradox formation. Beneath the salt-bearing beds and extending to the bottom of the well is 170 feet of variegated shale containing fresh water that may be the equivalent of the Molas formation. Beneath the anhydrite that was encountered in the Phillips Petroleum Co. well on the Spur and that is correlated with the Paradox formation, the well was drilled in cream-colored dolomite extending 400 feet to the bottom of the well. Dolomite of that color and thickness is unknown in the region but it may be equivalent to the Mississippian Leadville limestone of western Colorado and the Redwall limestone of the Grand Canyon district, Colo. ${ }^{10}$ A well drilled in Dark Canyon about 30 miles east of the mouth of the Dirty Devil River passed through rocks correlated with the Paradox formation and then penetrated over 2,400 feet of rocks consisting predominantly of gray or white limestone but including interbedded red, blue, and black limestone, gray, pink, and black shale, and some sandstone that-rests upon crystalline rocks. The upper part of this thick limestone series, and possibly all of it, presumably is equivalent to the Mississippian limestone exposed in western Colorado and northern Arizona. Thus the stratigraphic position of the Paradox formation is between the overlying Pennsylvanian Hermosa formation and underlying rocks presumably of Pennsylvanian or Mississippian age.

\footnotetext{
${ }^{9}$ Cross, Whitman, Howe, Ernest, and Ransome, F. L., U. S. Geol. Survey Geol. Atlas, Silverton folio (no 120), p. 4, 1905 .

${ }^{10}$ Noble, L. F., A section of the Paleozoic formations of the Grand Canyon at the Bass Trail: U. S. Geol. Survey Prof. Paper 131, pp. 54-57, 1922.
} 
Few fossils have been obtained from the Paradox formation. ${ }^{11}$ Conodonts were found in drill cuttings from a well drilled on the Cane Creek anticline about 9 miles southeast of Moab, Utah, and a few invertebrates and plants have been collected from outcrops of the formation. The fossil evidence, although meager, strongly suggests a lower Pennsylvanian age.

Very little information is available regarding the normal thickness of the Paradox formation. Outcrops such as those in Cataract Canyon and farther east in Utah are not helpful in determining the thickness because of the contortion and brecciation of the bedding and because the rocks at none of these outcrops are in normal stratigraphic position. Information obtained from many drilled wells in southeastern Utah seems to indicate a tremendous eastward thickening of the formation. However, it is believed that flowage in the salt-bearing beds has caused considerable thickening of the formation at the crests of anticlines so that the thicknesses of the formation determined in wells drilled on anticlines is probably considerably greater than the normal thickness. The western margin of the basin of deposition probably was somewhere between the San Rafael Swell and the well of the Phillips Petroleum Co. on the Spur. As mentioned above, no rocks that could be correlated with the Paradox formation were encountered in the wells drilled on the Swell, whereas the Phillips well encountered 700 feet of anhydrite that is believed to represent the full thickness of the Paradox formation. The western margin of the basin of deposition probably had a southeasterly trend and was only a short distance west of the Dark Canyon well which was drilled about 30 miles east of the mouth of the Dirty Devil River and encountered 330 feet of interbedded limestone, shale, and salt correlated with the Paradox formation. Toward the east a well drilled on the Shafer Dome on the Colorado River in T. 27 S., R. 20 E., passed through 3,900 feet of the salt series and probably reached older rocks underlying the Paradox formation. A well drilled in Salt Valley east of Green River in Sec, 13, T. 23 S., R. 20 E. drilled through about 2,250 feet of the salt series and a well drilled in Paradox Valley in southwestern Colorado drilled through more than 6,000 feet of the salt series. At neither of these localities did the wells reach the base of the series.

The type locality of the Paradox formation is in Paradox Valley in southwestern Colorado. The continuity of the formation between the Green River Desert-Cataract Canyon region and the type locality is firmly established. It crops out at several localities

\footnotetext{
${ }^{11}$ Baker, A. A., Dane, C. H., and Reeside, J. B., Jr., Paradox formation of eastern Utah and western Colorado: Am. Assoc. Petroleum Geologists Bull., vol. 17, pp. 971-972, 1933.
} 


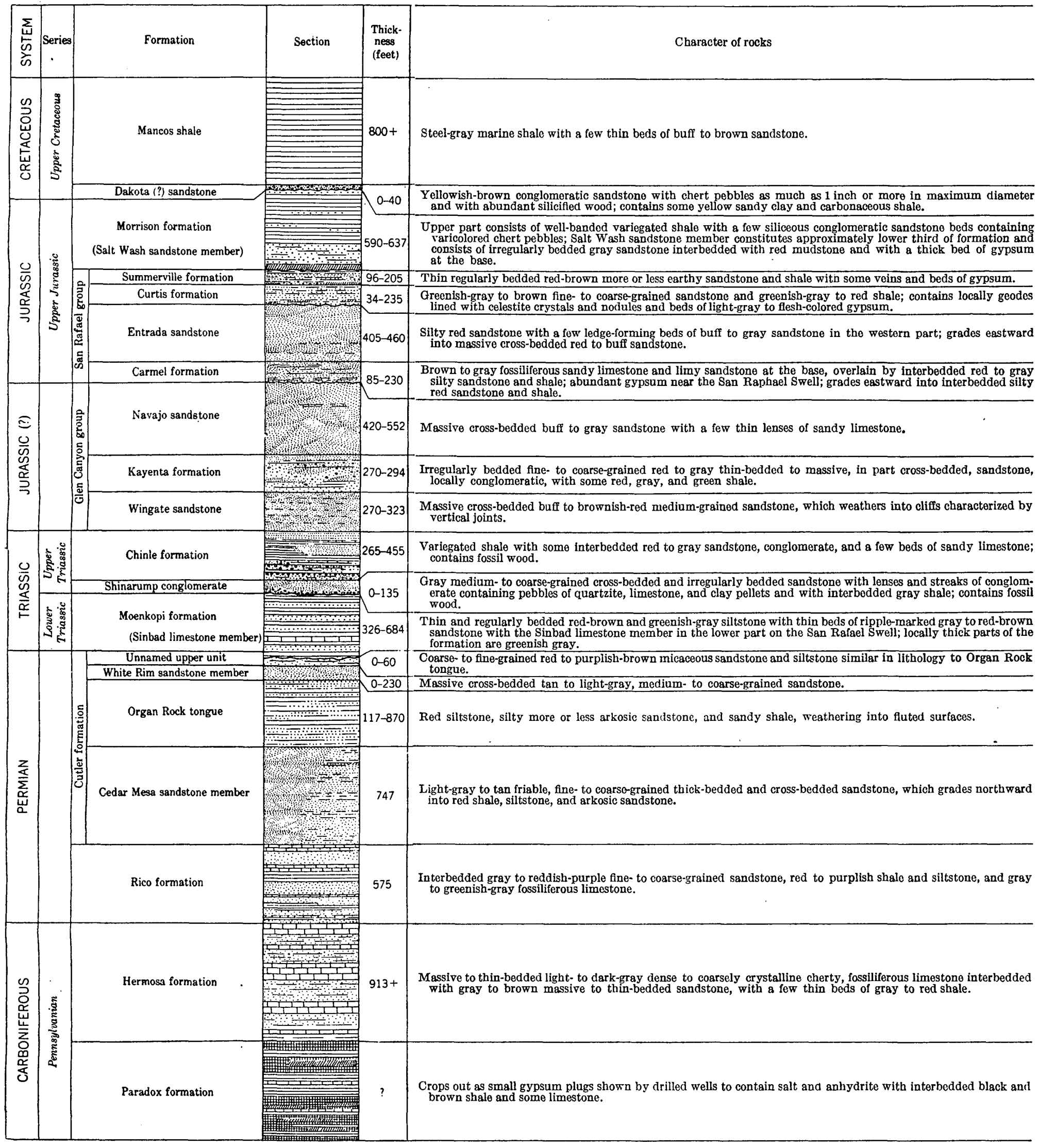

ROCKS EXPOSED IN THE REGION EXCLUSIVE OF THE CARBONIFEROÜS AND PERMIAN ROCKS OF THE SAN RAFAEL SWELL.

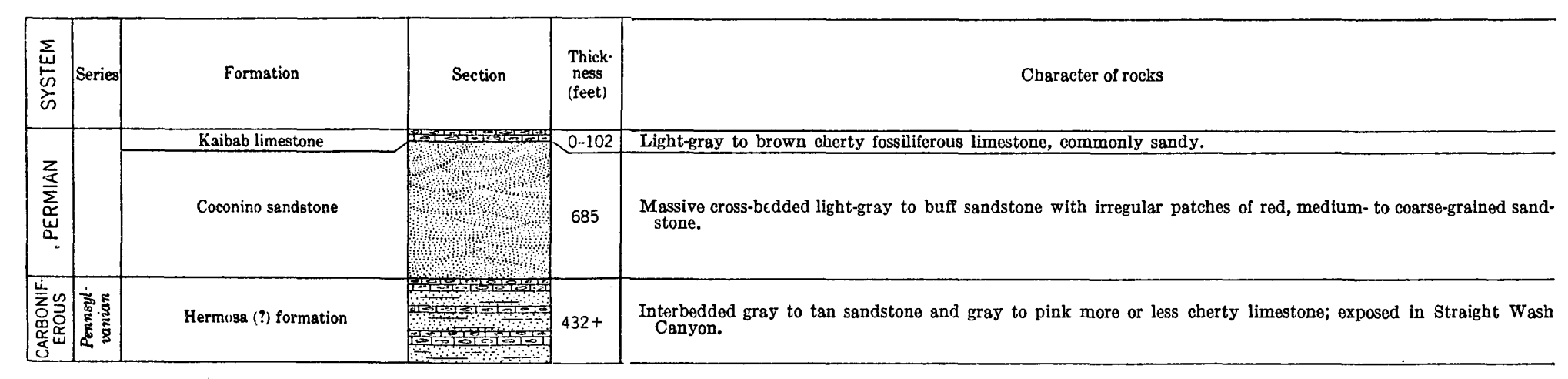

CARBONIFEROUS AND PERMIAN ROCKS EXPOSED IN THE SAN RAFAEL SWELL.

GENERALIZED COLUMNAR SECTION OF THE ROCKS EXPOSED IN THE GREEN RIVER DESERT-CATARACT CANYON REGION, UTAH. 
in the intervening area and every well drilled to sufficient depth in that part of Utah has encountered the formation.

HERMOSA FORMATION

Rocks correlated with the Hermosa formation crop out in the steep walls of the canyons of the Green and Colorado Rivers and in Straight Wash in the San Rafael Swell. In the Green River canyon the Hermosa rises above river level about 9 miles above the junction with the Colorado River ; it forms the lower canyon walls along Green River (pl. 6, $A$ ) and along Cataract Canyon (pl. 4, $A, 5, A$ ) to Mille Crag Bend where it dips below the surface of the Colorado River about 8 miles above the mouth of the Dirty Devil River. The limestone of the Hermosa is resistant to erosion and is the principal rock controlling the development of the precipitous walls, steep gradient and numerous rapids of Cataract Canyon. This outcrop of the Hermosa is located in one of the most inaccessible parts of the area in a deep canyon rimmed by cliffs which are impassable practically everywhere. The area of outcrop above Cataract Canyon can be reached by boat from Moab on the Colorado River or from the town of Green River on the Green River, but rapids prohibit ordinary boat travel in Cataract Canyon. The only trail known to the writer leading to the Colorado River from the west side is the Spanish Trail that leads to Spanish Bottom at the head of Cataract Canyon. In the San Rafael Swell, the rocks tentatively correlated with the Hermosa crop out in the canyon of Straight Wash at a place that can be reached only with great difficulty. Because of the inaccessibility of its outcrop, the Hermosa was examined only on the Spanish Trail and in Straight Wash. However, it has been examined along the Green River by McKnight ${ }^{12}$ and along the Colorado River, a few miles above the junction, by Reeside. ${ }^{13}$

The Hermosa formation along the Colorado and Green Rivers consists predominantly of interbedded massive limestone and sandstone in about equal proportions but contains some thin-bedded sandstone, limestone, and shale. The massive beds of limestone and sandstone form a series of ledges separated by steep slopes formed by shale and thinner-bedded sandstone and limestone. The limestone occurs in beds up to 45 feet or more thick. It is light to dark gray, dense to coarsely crystalline, and many of the beds contain abundant chert; the chert occurs as elongated gray nodular masses and as red chips or flakes. Most of the limestone beds are abundantly fossiliferous. Sandstone beds range in thickness up to

\footnotetext{
12 McKnight, E. T., Geology of area between Green and Colorado Rivers, Grand and San Juan . Counties, Utah: U. S. Geol. Survey Bull. 908, 1940 [1941].

${ }^{13}$ Reeside, J. B., Jr., in Baker, A. A., Geology and oil possibilities of the Moab district, Grand and San Juan Counties, Utah: U. S. Geol. Survey Bull. \$41, pp. 20-21, 1933.
} 
50 feet. The dominant color of the sandstone is gray, but a few beds are buff, olive drab, chocolate brown, or salmon pink. The sandstone is medium- to fine-grained and consists largely of quartz, although some beds contain abundant mica and some are arkosic. Cross bedding is common and large ripple marks were observed at one locality. The Hermosa formation contains a few thin beds of shale of chocolate brown, red, gray, or white color.

The following section, measured along Spanish Trail at the head of Cataract Canyon, is a typical section of the upper part of the Hermosa formation along the Green and Colorado Rivers :

Section of upper part of Hermosa formation measured at Spanish Trail Rico formation.

Hermosa formation:

1. Limestone, gray, ccarsely crystalline, fossiliferous.

2. Sandstone, light-gray, fine-grained, cross-bedded.

3. Limestone, gray, coarsely crystalline, fossiliferous, ledgeforming

4. Sandstone, gray, medium-grained, soft.

5. Limestone, dark-gray, coarsely - crystalline, cherty, fossiliferous, ledge-forming

6. Sandstone, buff to greenish-gray, fine-grained, soft...

7. Limestone, dark-gray, coarsely crystalline, fossiliferous..

8. Sandstone, buff to greenish-gray, medium- to coarse-grained, cross-bedded

9. Sandstone, light chocolate-brown, soft, nodular-weathering..................

10. Shale, chocolate-brown ..................................... Sandstone, olive-drab to light-gray, micaceous, crodded; has a few large ripple marks.

12. Limestone, coarsely crystalline, thin-bedded, cherty, fossiliferous, with some interbedded dark-gray shale.

13. Limestone, dark-gray, coarsely crystalline, massive, cherty, fossiliferous; forms lower of two ledges in upper part of Hermosa

14. Shale, red to dark-gray.

15. Sandstone, light-gray, fine-grained, soft, minutely cross-bedded

16. Limestone, greenish-gray, coarsely crystalline, massive, fossiliferous

17. Limestone, light-gray, sandy, cherty, fossiliferous...

18. Sandstone, light-gray, soft, cross-bedded.

19. Limestone, gray, dense, cherty, fossiliferous.

20. Sandstone, light-gray, fine-grained, massive, cross-bedded

21. Limestone, gray, dense, massive, fossiliferous; contains nodules of black chert.

22. Shaly sandstone, light-gray, soft.

23. Limestone, gray, cherty, fossiliferous...

24. Sandstone, light-gray to salmon-pink, fine-grained, micaceous, soft, with few beds of purplish shale.

25. Shale, dark-gray

26. Limestone, gray, cherty, fossiliferous...

27. Sandstone, dark-gray, medium-grained, micaceous 
28. Sandstone, light-gray to light salmon-pink, fine-grained

29. Sandstone, gray to pink, coarse-grained, arkosic, cross-bedded.....

30. Sandstone, limy, light-gray, platy.

31. Limestone, gray, fossiliferous, massive, ledge-forming; contains chert in elongated gray nodules and red chips.

32. Sandstone, light-gray to light salmon-pink, fine-grained..

33. Shale, sandy, red.

34. Sandstone, light salmon-pink, fine-grained

35. Limestone, sandy at base, light-gray, fossiliferous; contains chips of red chert....

36. Sandstone, light-gray, fine-grained

37. Limestone, dark-gray, ledge-forming, fossiliferous; contains chert in elongated gray nodules and abundant red chips.

38. Sandstone, light-gray, fine-grained, thin-bedded, soft...

39. Limestone, gray thin-bedded, abundantly fossiliferous, cherty.....

40. Limestone, composed largely of shells............................................... 1

41. Sandstone, light-gray

42. Limestone, gray, thin-bedded with interbedded greenish-gray sandstone; limestone contains red siliceous fossils and elongated chert nodules.

43. Limestone, gray, dense to coarsely crystalline, fossiliferous; contains abundant chert as red masses less than an inch in maximum diameter and elongated gray nodules 2 feet or more in length and about 3 inches thick

44. Shale, limy, white.

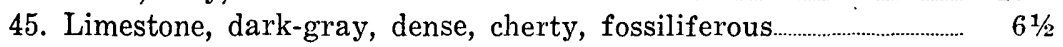

46. Sandstone, light-gray, medium to fine-grained, massive...................... 19

Alluvium to river level.

The oldest rocks exposed in the San Rafael Swell crop out in isolated exposures in the canyons of the San Rafael River ${ }^{14}$ and Straight Wash. They consist of an alternating series of massively bedded buff to gray marine limestone and sandstone whose age has not been determined. They underlie the massive Permian sandstone and thus occur in the stratigraphic position normally occupied by the Rico formation in southeastern Utah. The absence of red colors in these rocks suggests that they are not equivalent to the Rico formation. Like the Hermosa, however, the rocks are dominantly gray or buff and the limestone contains nodules of red and gray chert. Examination of cuttings from the wells drilled by the Standard Oil Co. in the San Rafael Swell (see records of wells p. 117) discloses that these rocks are only about 600 feet thick and are underlain by a great thickness of dolomite, which is correlated with the dolomite that underlies the anhydrite of the Paradox formation in the Phillips Petroleum Co. well and is believed to be of Mississippian age. Accordingly, these rocks are believed to be most probably equivalent to the Hermosa and in this report are tentatively assigned to that formation.

14 Gilluly, James, Geology and oil and gas prospects of part of the San Rafael Swell, Utah: U. S. Geol. Survey Bull. 806, p. 81, 1929. 
The following section measured by A. J. Eardley shows the lithologic character of the rocks in the San Rafael Swell tentatively assigned to the Hermosa :

Section of the Hermosa (?) formation exposed in the canyon of Straight Wash Coconino sandstone.

Hermosa (?) formation:

1. Limestone, sandy, thin-bedded, fossiliferous; contains white granular chert nodules.

2. Sandstone, tan; pitted on weathered surface

3! Sandstone, pale-buff; has a few limonitic patches............................... 33

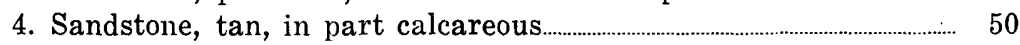

5. Limestone and sandstone interbedded...................................................... 33

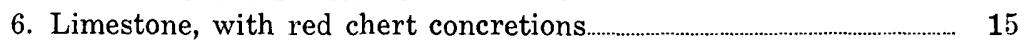

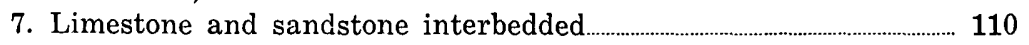

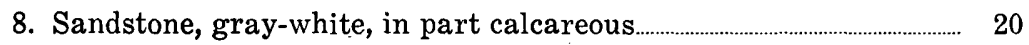

9. Limestone, buff, dense, in part thick-bedded.................................... 50

10. Limestone on channeled surface of sandstone............................................ 3

11. Sandstone, friable ............................................................................... 20

12. Limestone, buff, dense, hard $\ldots$

13. Sandstone, medium-grained, calcareous, massive.................................. 15

14. Sandstone, thin-bedded, friable .................................................................... 3

15. Limestone, gray, massive; weathers buff and pitted; contains some irregular pink-limestone lenses with quartz pebbles........... $\quad 30$

16. Limestone, gray, dense to coarsely crystalline, massive fossiliferous; contains large chert nodules.

Base concealed.

The Hermosa formation is not completely exposed in the Green River Desert-Cataract Canyon region nor at any other known locality in southeastern Utah, and information concerning its full thickness must be obtained from drill records. The partial section of the formation, 716 feet thick, measured on.the Spanish Trail, may be complicated by faulting at that locality associated with the arching of the rocks over the plug of the Paradox formation at the mouth of Red Lake Canyon. At The Slide on the Colorado River, about 11/2 miles above the mouth of the Green River, Reeside ${ }^{15}$ measured 913 feet of the formation with the base concealed. The J. H. Shafer No. 1 well, drilled on the bank of the Colorado River about 20 miles northeast of the mouth of the Green River, started about 150 feet.below the top of the Hermosa and drilled through 1,610 feet of rocks assigned to the Hermosa, although it is possible that several hundred feet at the base should be assigned to a transition zone between the Hermosa and the underlying Paradox formation. Similarly the Frank Shafer No. 1 well drilled on the bank of the Colorado River about 25 miles northeast of the mouth of the Green River, started about 300 feet below the top of the

\footnotetext{
13 Reeside, J. B., Jr., in Baker, A. A., Geology and oil possibilities of the Moab district, Grand and San Juan Counties, Utah: U. S. Geol. Survey Bull. 841, pp. 20-21, 1933.
} 
Hermosa and drilled through 1,475 feet of rocks that overlie the Paradox formation. Thus the total thickness of the Hermosa formation, as indicated by the records of these two wells, is nearly ' 1,800 feet. East of the Colorado River a well was drilled in a tributary of, Dark Canyon about 20 miles from its junction with the Colorado River, which passed through 1;465 feet of beds assigned to the Hermosa formation, although the lower 300 feet contain a large amount of black shale that may be part of the underlying Paradox formation.

A few wells drilled within the Green River Desert-Cataract Canyon region presumably passed through complete thicknesses of the Hermosa formation. The well drilled by the Phillips Petroleum Co. on the Spur passed through approximately' 1,300 feet of rocks, between depths of 2,815 and 4,100 feet, which is probably the full thickness of the Hermosa. The thickness of the Hermosa thus appears to decrease westward from approximately 1,800 feet on the Colorado River to approximately 1,300 feet on the Spur in a distance of about 25 miles. Wells drilled by the Standard Oil Co. near the crest of the San Rafael Swell penetrated about 600 feet of strata below the Permian Coconino sandstone, which represents a complete thickness of the rocks tentatively correlated with the Hermosa, thus indicating a further-westward decrease in thickness of approximately 700 feet in a distance of 36 miles.

Marine invertebrate fossils are abundant in the Hermosa formation. Collections, identified by G. H. Girty, that have been made along the Colorado and Green Rivers above their junction are listed in other reports. ${ }^{16}$ The fossils establish the age of the formation as Pennsylvanian. The fossils, lithology, and stratigraphic position of the formation clearly establish the correlation with the type locality of the Hermosa formation in the San Juan Mountains, Colo., ${ }^{17}$ and with rocks exposed in the canyon of the San Juan River, Utah. ${ }^{18}$ Toward the southwest the Hermosa formation wedges out either by overlap upon older rocks or because of erosion subsequent to their deposition, as rocks of Pennsylvanian age are absent where the Paleozoic rocks reappear at the surface in the vicinity of Grand Canyon National Park in northern Arizona. ${ }^{19}$

\footnotetext{
${ }^{16}$ Baker, A. A., Geology and oil possibilities of the Moab district, Grand and San Juan Counties, Utah: U. S. Geol. Survey Bull. 841, p. 22, 1933. McKnight, E. T., Geology of area between Green and Colorado Rivers, Grand and San Juan Counties, Utah: U. S. Geol, Survey Bull. 908, 1940 [1941].

${ }^{17}$ Cross, Whitman, U. S. Geol. Survey Geol. Atlas, Rico Folio (no.' 130), 1905.

${ }^{18}$ Baker, A. A., Geology of the Monument Valley-Navajo Mountain region, San Juan County, Utah: U. S. Geol. Survey Bull. 865, pp. 18-23, 1936.

${ }^{10}$ White, David, Flora of the Hermit shale, Grand Canyon, Ariz. : Carnegie Inst. Washington Pub. 405, p. 5, 11, 1929. Stoyanow, A. A., Correlation of Arizona Paleozoic formations: Geol. Soc. America Bull., vol. 47, pp. 514-516, 1936.
} 


\section{PERMIAN SYSTEM}

\section{GENERAL FEATURES}

The Rico formation includes the oldest Permian rocks in southeastern Utah; it shows little variation in lithology and thickness throughout most of. its known extent in that part of the State. The younger Permian rocks, however, show a great lateral change in lithology and in the thickness of the different units. In western Colorado the post-Rico Permian rocks, all of which are included in the Cutler formation, consist of red beds. Toward the west, in southeastern Utah, in the vicinity of the mouth of the Green River, white sandstone members are interbedded with the red beds. Farther westward and west of a belt of country in which the Permian formations are concealed by younger rocks, the sequence of strata is similar to that present at the Grand Canyon of the Colorado River in northern Arizona, where the Permian consists of the Kaibab limestone at the top underlain successively by the gray to buff Coconino sandstone, the red Hermit shale, and the red Supai formation, which rests upon pre-Permian rocks. The belt of country occupied by rocks younger than Permian extends through the Green River Desert between the San Rafael Swell and the canyons of the Green and Colorado Rivers; in the San Rafael Swell the sequence of rocks is similar to the upper part of the Grand Canyon Permian but, where the Permian rocks are exposed in the canyons of the two rivers, these rocks can be more definitely correlated with the Permian sequence of western Colorado.

The regional correlation and the history of the development of the nomenclature of the Permian rocks in this region have been described in another publication ${ }^{20}$ and will be discussed in this report only to the extent that they bear directly upon the descriptions of the Permian formations that crop out in the Green River Desert-Cataract Canyon region.

RICO FORMATION

The Rico formation crops out in the Green River DesertCataract Canyon region only in the canyons of the Green and Colorado Rivers and for short distances along their tributary canyons. It crops out at the water level of the Green River about $161 / 2$ miles upstream from the junction with the Colorado River. At the junction of the two rivers and through most of Cataract Canyon it crops out high on the canyon walls. In the lower part

\footnotetext{
${ }^{20}$ Baker, A. A., and Reeside, J. B., Jr., Correlation of the Permian of southern Utah, northern Arizona, northwestern New Mexico, and southwestern Colorado: Am. Assoc. Petroleum Geologists Bull., vol. 13, pp. 1413-1448, 1929.
} 
of Cataract Canyon where the Colorado River makes a great bend to the west and flows more or less in the direction of the dip of the formations, the Rico formation dips down to river level, and its belt of outcrop ends about $21 / 2$ miles above the mouth of the Dirty Devil River.

The outcrop of the Rico formation forms a steep slope, which is marked by numerous ledges and which rises steeply from the top of the cliffs formed by the underlying Hermosa formation to the foot of the cliffs formed by the overlying Cedar Mesa sandstone member of the Cutler formation. (See pls. 5, $A, 6, A$.) The outcrop of the formation is accessible at few places and was examined in detail only along the Spanish Trail at the head of Cataract Canyon, However, considerable information concerning the formation is available from examinations in adjoining regions. ${ }^{21}$

The Rico formation consists of interbedded sandstone, shale, siltstone, and limestone, with sandstone predominating. The sandstone is gray, buff, salmon pink, red, lavender, or purple; fine to coarse-grained with some grit; quartzose or arkosic; cross-bedded in part, and thin-bedded to massive. Most of the sandstones are thick-bedded and commonly form ledges, although the bedding is irregular. Numerous beds of red to purplish shale and siltstone and gray to greenish-gray fossiliferous limestone are interbedded with the sandstone. A gray cherty fossiliferous limestone bed, 20 feet thick and 61 feet below the top of the formation, is locally called the Shafer limestone; it is a prominent member of the formation along the Colorado River between its junction with the Green River and a locality a few miles southwest of Moab. The Rico formation is 422 feet thick as measured on the Spanish Trail, but its thickness has been measured as 575 feet on the Colorado River about $11 / 2$ miles above the mouth of the Green River, and still farther to the northeast at a locality a few miles southwest of Moab. ${ }^{22}$ It therefore seems probable that the measurement of 422 feet at Spanish Trail is less than the normal thickness and that it probably is due to cutting out of beds by small faults which are numerous in that vicinity. About 50 miles southeast of the mouth of the Dirty Devil River the Rico formation crops out along the San Juan River, where it is 458 to 473 feet thick. ${ }^{23}$

\footnotetext{
${ }^{21}$ Baker, A. A., Geology and oil possibilities of the Moab district, Grand and San Juan Counties, Utah: U. S. Geol. Survey Bull. 841, pp. 23-29, 1933. McKnight, E. T., Geology of area between Green and Colorado Rivers, Grand and San Juan Counties, Utah: U. S. Geol. Survey Bull. 908. 1940 [1941].

${ }^{22}$ Baker, A. A., op. cit., pp. 24-25.

${ }^{23}$ Baker, A. A., Geology of the Monument Valley-Navajo Mountain region, San Juan County,

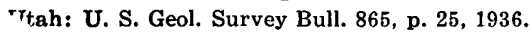


The following section is typical of the lithology of the Rico formation:

Section of Rico formation measured along Spanish Trail on west side of Colorado River at head of Cataract Canyon

Cedar Mesa sandstone member of the Cutler formation.

Rico formation:

1. Limestone, sandy, gray, grading laterally into red fine-grained, thin-bedded sandstone

2. Sandstone, buff, coarse-grained, poorly cemented, grading upward into hard, fine-grained sandstone; contains some quartzpebble grit

3. Sandstone, light-gray to pale-lavender, fine-grained to coarsegrained, thick-bedded and regularly bedded, ledge-forming.......

4. Limestone, gray, cherty, thick-bedded, fossiliferous (Shafer limestone)

5. Sandstone, red to purple, micaceous, fine-grained

6. Sandstone, gray, streaked with pale lavender, coarse-grained, arkosic, massive, ledge-forming.

7. Sandstone, salmon-pink, medium- to fine-grained

8. Shale, red to purple

9. Sandstone, purplish, arkosic, coarse-grained, cross-bedded.

10. Siltstone, red

11. Sandstone, salmon-pink, cross-bedded, ledge-forming .......................... 3

12. Shale, red, sandy, and thin platy sandstone.

13. Sandstone, grayish-purple to purplish-red, arkosic, massive.......... 6

14. Shale, red

15. Sandstone, brick-red, thin-bedded, minutely cross-bedded................. 11

16. Limestone, greenish-gray, sandy, fossiliferous.................................... 2

17. Arkose, grayish-purple, massive, ledge-forming............................. 65

18. Limestone, gray, dense

19. Sandstone, red, fine-grained, thin-bedded at base, grading upward into massive, coarse-grained, purple arkose.

20. Arkose, grayish-purple, coarse-grained, cross-bedded, ledgeforming

21. Limestone, gray, dense.

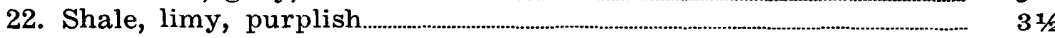

23. Limestone, sandy, light-gray, ledge-forming, fossiliferous............... 121/2

24. Sandstone, purple, coarse-grained, nodular-weathering, grades laterally into red, fine-grained, shaly sandstone ....................... $18 \mathrm{1} \frac{1}{2}$

25. Sandstone, light-gray, coarse-grained.................. 1

Hermosa formation.

Throughout the region between the Colorado and Green Rivers and the San Rafael Swell the horizon of the Rico formation is deeply buried beneath younger rocks. The well drilled by the Phillips Petroleum Co. on the Spur penetrated rocks older than the Rico formation, but the Hermosa and Rico formations cannot be differentiated satisfactorily on the basis of the drillers' descriptions. The well was apparently drilled in undifferentiated Hermosa and Rico between depths of 2,555 and 4,100 feet, but only 


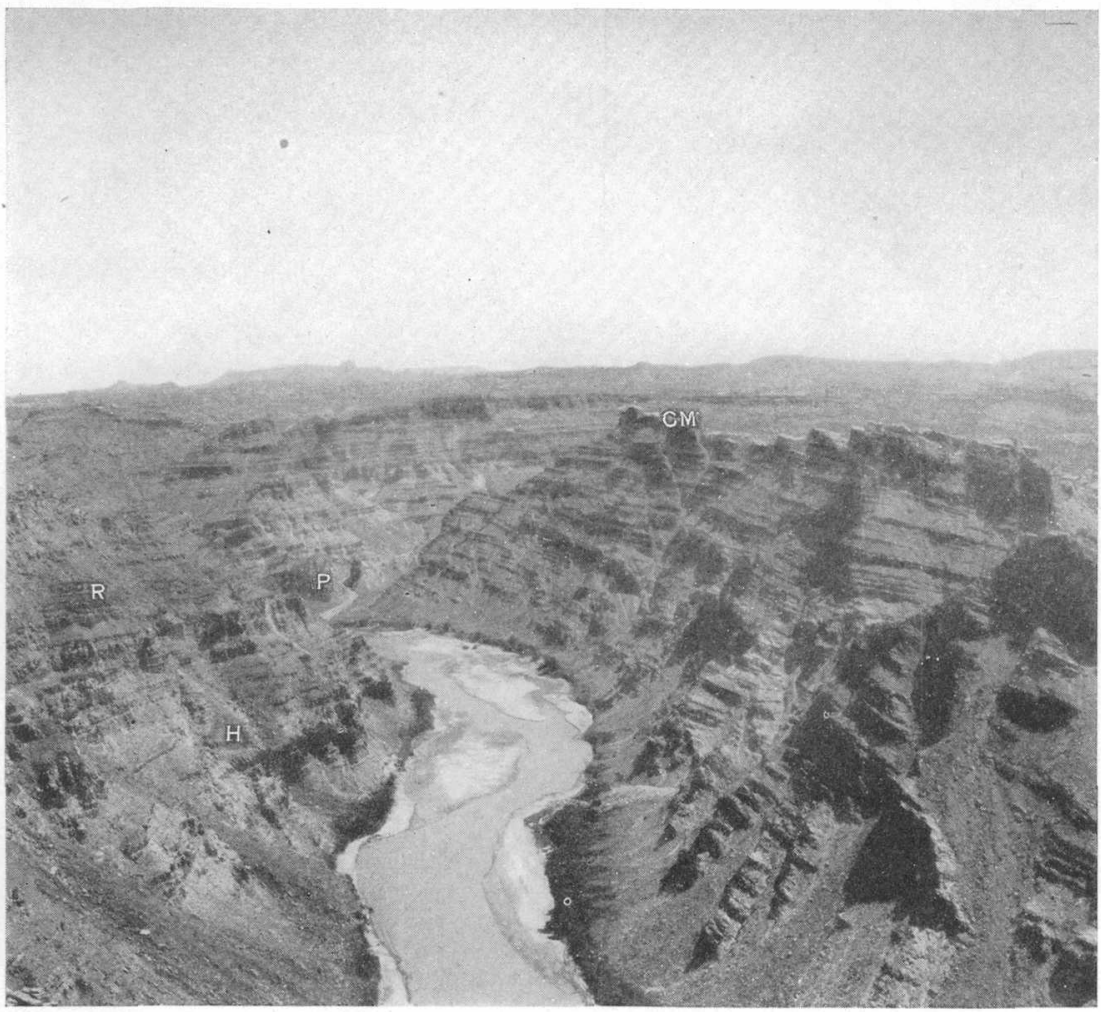

\section{A. VIEW UPSTREAM ALONG CATARACT CANYON}

Showing the gypsum plug of Paradox formation in Cataract Canyon, about 8 miles southwest of mouth of Green River at mouth of the tributary canyon in background. P, Paradox formation; H, Hermosa formation; R, Rico formation; and CM, lower part of Cedar Mesa sandstone member of Cutler formation.

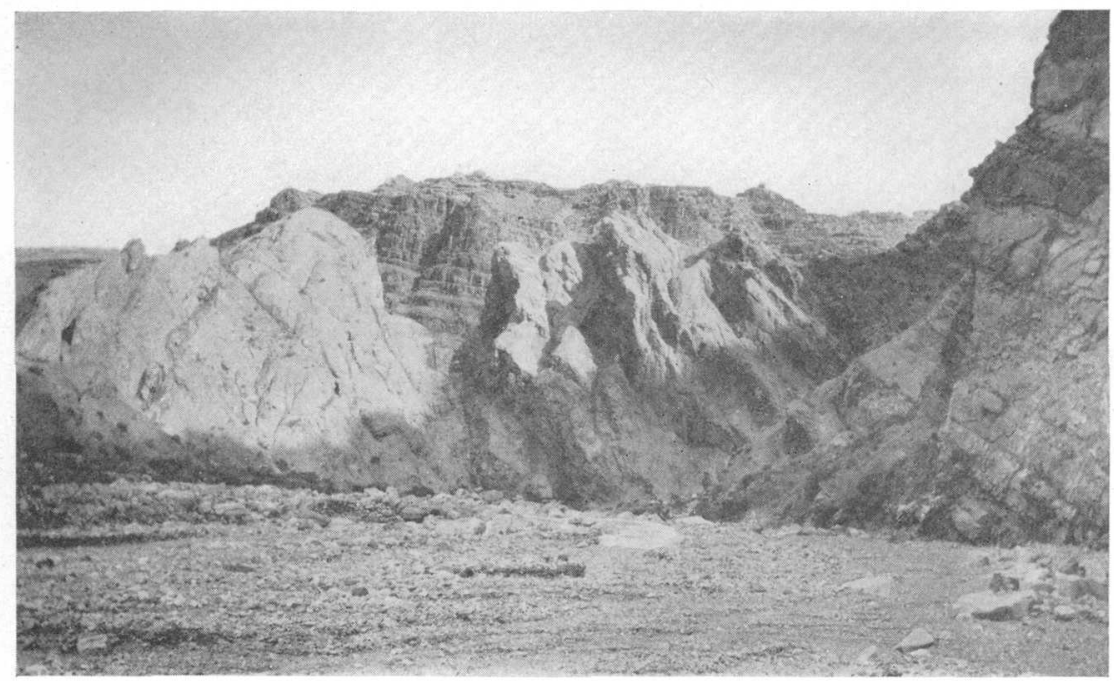

B. NEAR VIEW OF GYPSUM PLUG SHOWN IN PLATE $4, A$, LOOKING DOWNSTREAM IN TRIBUTARY CANYON.

The contact of the gypsum cuts across Hermosa strata at the right. Photograph by Sidney Paige. 


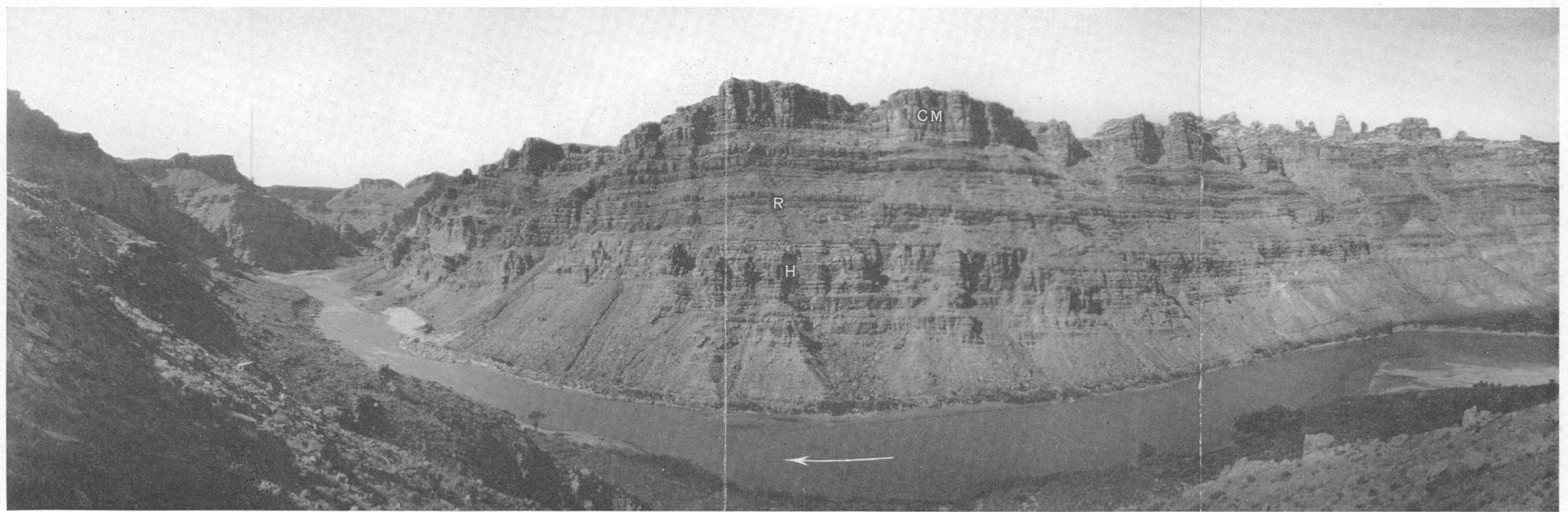

A. VIEW OF HEAD OF CATARACT CANYON.

Shows steep slopes and cliffs of the canyon walls; on skyline at right are spires carved from the Cedar Mesa sandstone, CM. H, Hermosa formation; R, Rico formation. Photograph by E. C. LaRue.

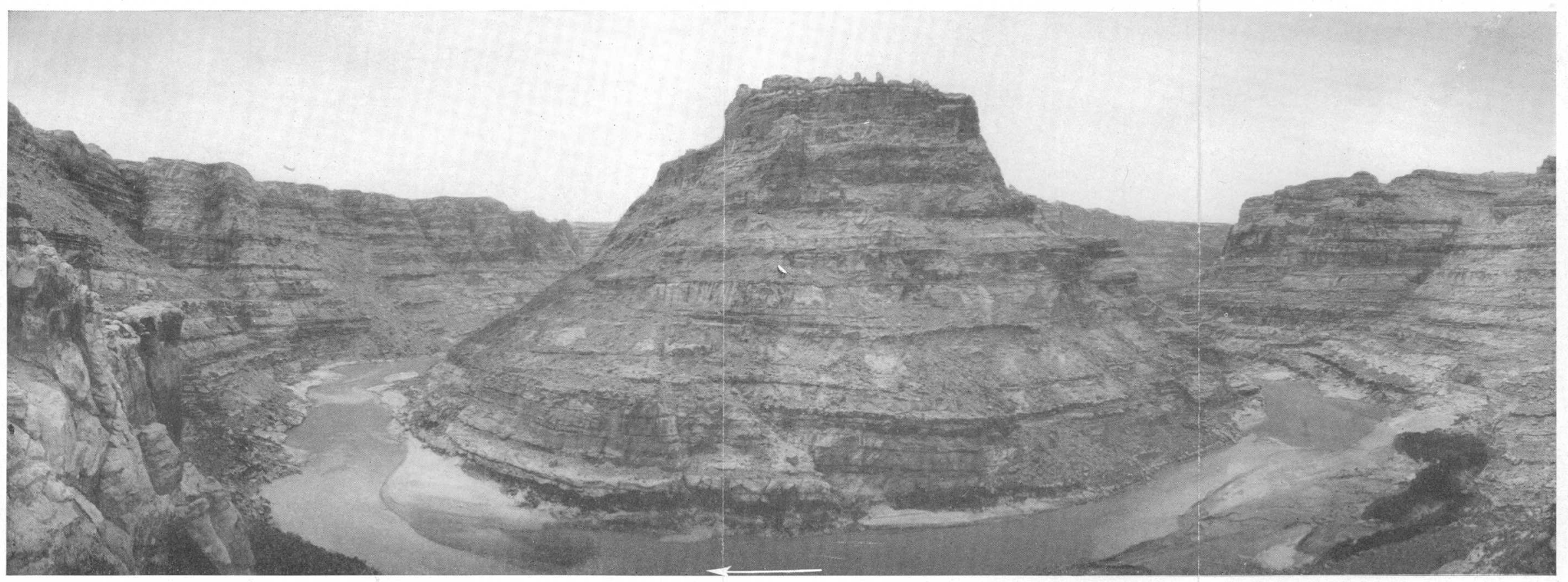

B. MILLE CRAG BEND NEAR LOWER END OF CATARACT CANYON.

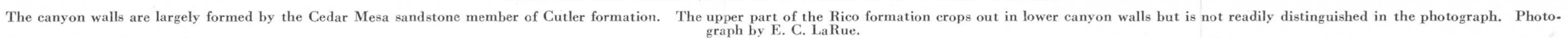




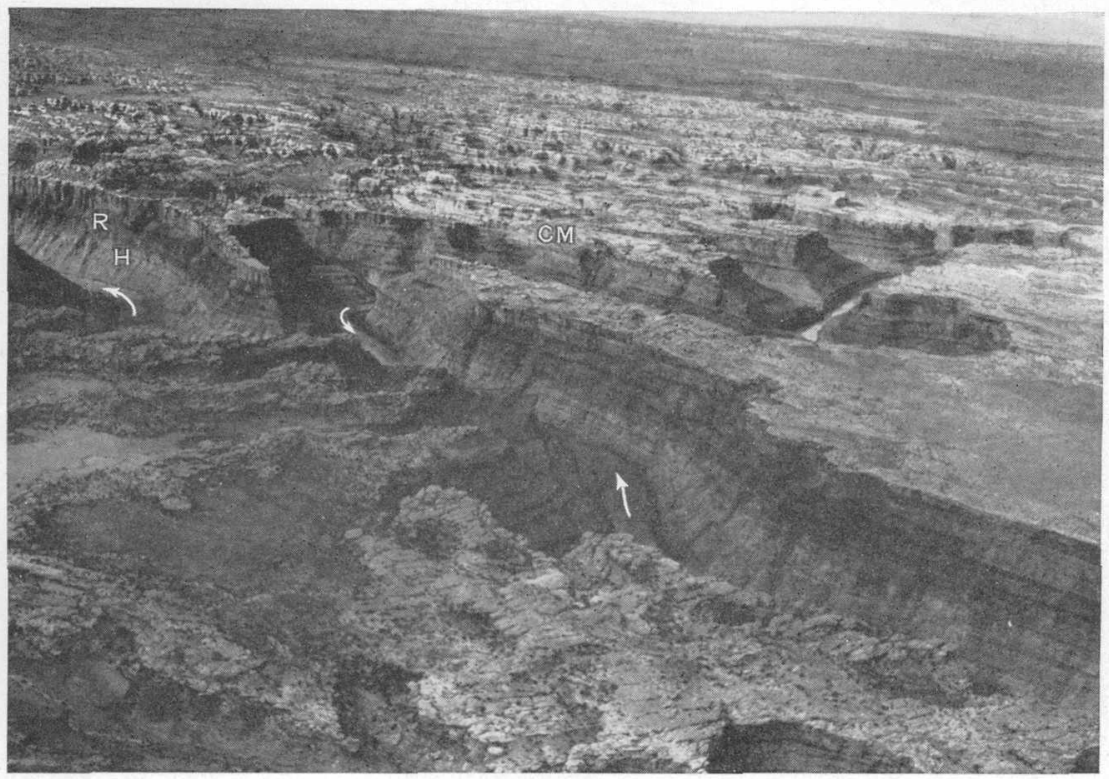

A. AERIAL VIEW OF JUNCTION OF GREEN AND COLORADO RIVERS. .

Colorado River in foreground and Green River in rigbt background; H, Hermosa formation; R, Rico formation; CM, Cedar Mesa sandstone member of Cutler formation. Photograph by National Park Service.

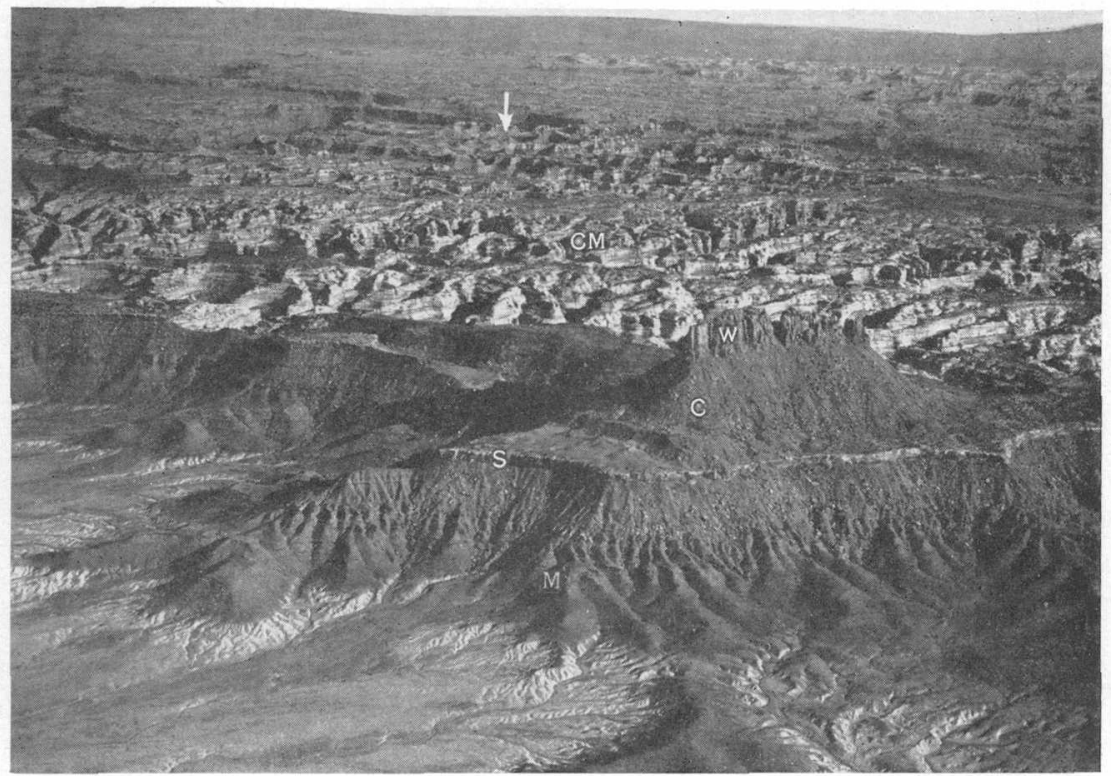

B. AERIAL VIEW OF DISSECTED SURFACE WEST OF MOUTH OF GREEN RIVER WITH ELATERITE BUTTE IN FOREGROUND.

Note the bleached beds in lower part of Moenkopi formation in foregr and; CM, Cedar Mesa sandstone member of Cutler formation: M. Moenkopi formation; S, Shinarump conglomerate; C, Chinle formation; W, W ingate sandstone. Arrow points to junction of Green and Colorado Rivers. Photograph by National Park Service. 
the upper 170 feet contain red beds suggestive of the Rico. In the San Rafael Swell the oldest rocks exposed are gray, buff, or yellowish sandstone and limestone, which underlie the massive Permian Coconino sandstone. On the basis of lithology these rocks are tentatively correlated with the Hermosa formation (see p. 29), and it is inferred that the Rico formation wedges out westward somewhere east of the San Rafael Swell. Southwest of the Green River Desert-Cataract Canyon region, where the Permian rocks reappear at the surface in the Grand Canyon region of Arizona, the Rico formation is absent although it is possible that the Supai formation is in part equivalent to it.

The Rico formation conformably overlies the Hermosa formation. The contact is marked approximately by the lower limit of the relatively thin bedding characteristic of the Rico formation as contrasted with the underlying cliff-forming, massive beds of limestone and sandstone of the Hermosa formation. Similarly, the contact is marked by the change from relatively abundant red rocks in the Rico formation to gray rocks with practically no red in the Hermosa formation. The fossils contained in the two formations show a fairly sharp faunal change approximately coincident with the lithologic change, but at least locally there is a thin lithologic transition zone consisting of thin-bedded sandstone or shale beds, which weather in a slope receding from the top of the Hermosa cliff and contain fossils of Hermosa type. ${ }^{24}$

Within the Green River Desert-Cataract Canyon region there is a sharp contact between the Rico formation and the overlying light-colored massive sandstone of the Cedar Mesa sandstone member of the Cutler formation; the limestone at the top of the Rico is believed to be persistent throughout the area, and therefore to show that the contact is consistently at the same horizon. Along the canyon of the Colorado River upstream from the mouth of the Green River, however, this limestone at the top of the Rico wedges out and the unit locally called Shafer limestone, about $\mathbf{7 0}$ feet lower in the formation, is the uppermost limestone; a few miles southwest of Moab the Shafer limestone also wedges out and a limestone bed 45 feet below the Shafer is the uppermost fossiliferous bed in the Rico formation. ${ }^{25}$ Along the Colorado River between the mouth of the Green River and Moab the Cutler formation consists predominantly of unfossiliferous arkosic red beds similar in lithology to the rocks interbedded with the limestone of the Rico formation, and the contact beween the Cutler

\footnotetext{
${ }^{24}$ Baker, A. A., Geology and oil possibilities of the Moab district, Grand and San Juan Counties, Utah: U. S. Geol. Survey Bull 841, p. 21, 1933; Geology of the Monument Valley-Navajo Mountain region, San Juan County, Utah: U. S. Geul. Survey Bull. 865, p. 21, 1936.

25 Baker, A. A., op. cit., Bull. 841, pp. 25-26, 1933.
} 
and Rico is arbitrarily placed at the top of the uppermost fossil. iferous limestone in conformity with the original definition of those formations. ${ }^{26}$ Northeast of Moab, along the Colorado River, limestone beds are absent and all the rocks between the Pennsylvanian Hermosa and the Triassic Moenkopi are included in the Cutler formation. ${ }^{27}$ It is therefore apparent that those formations, as defined in southeastern Utah, have an intertonguing relationship at their contact.

Fossils are abundant in most limestone beds of the Rico formation. Extensive collections have been made in other areas, and the fauna has been listed in other reports. ${ }^{28}$ The fossils establish the Permian age of the formation and its equivalence in southeastern Utah and southwestern Colorado.

Many beds in the Rico formation contain marine fossils, which proves the marine origin of parts of the formation. However, interbedded unfossiliferous beds separated from the marine beds at some localities by intraformational unconformities marked by channeled surfaces are probably in part of continental origin. The sediments of the Rico formation become coarser-grained toward the northeast and east, indicating a source in that direction, and the arkosic character of the sediments indicates that the source was probably the pre-Cambrian of western Colorado. Rapid deposition under fluviatile conditions is suggested by the coarseness of grain, thick irregular bedding, and cross bedding of the sediments. It seems probable that an aggraded plain sloping westward from highlands in western Colorado was periodically inundated by incursions of the sea; the distribution of the upper limestone beds, which are the only ones that have been separately traced, shows that the eastern margins of the last three incursions of the sea were progressively farther southwest.

\section{POST-RICO FORMATIONS}

CUTLER FORMATION

The Cutler formation crops out along Cataract Canyon of the Colorado River and for a few miles along the canyons of the Green and Dirty Devil Rivers near their mouths. It consists of two beds of massive light-gray sandstone separated by a thick series of red shale, siltstone, and sandstone. The lower massive

\footnotetext{
${ }^{26}$ Cross, Whitman, Howe, Ernest, and Ransome, F. L., U. S. Geol. Survey Geol. Atlas, Silverton folio (no. 120), p. 5, 1905.

${ }^{2 \tau}$. Dane, C. H., Geology of the Salt Valley anticline and adjacent areas, Grand County Utah: U. S. Geol. Survey Bull. 863, p. 41, 1935 [1936].

an MeKnight, E. T.. Geology of aren between Green nnd Colorndo Rivers. Grand and San Juan Counties, Utah: U. S. Geol. Survey Bull, 908, 1940 [1941], Baker, A. A., Geology and oil possibilities of the Moab district, Grand and San Juan Counties, Utah: U. S. Geol. Survey Bull. 841; pp. 27-28, 1933; Geology of the Monument Valley-Navajo Mountain region, San Juan County, Utah: U. S. Geol. Survey Bull. 865, pp. 26-27, 1936.
} 
light-gray sandstone has been named the Cedar Mesa sandstone member; the upper massive light-gray sandstone has been named the White Rim sandstone member. The Organ Rock tongue includes the red-bed series separating the light-gray sandstones. In part of the area a thin unnamed series of red beds similar in lithology to the Organ Rock tongue overlies the White Rim sandstone. Locally the White Rim sandstone is absent and in Green River Canyon, near the northern end of the outcrop of the Cutler formation, the Cedar Mesa sandstone changes laterally into red beds inseparable from the Organ Rock tongue, which at that locality includes nearly all the Cutler formation.

No fossils were found in the Cutler formation in the Green River Desert-Cataract Canyon region but its Permian age is established by the age of the enclosing formations and by diagnostic fossils found in parts of the formation at other localities in southeastern Utah. The Rico formation conformably underlying the Cutler formation is of Permian age, and the Cutler formation is the lateral equivalent of the Coconino sandstone of the San Rafael Swell, where the Coconino is overlain by the fossiliferous Kaibab limestone of Permian age. In the Monument ValleyNavajo Mountain region the Cutler contains plant and vertebrate fossils which have been determined to be of Permian age. ${ }^{29}$

Changes in thickness of the members of the Cutler formation and lateral changes in lithology are shown in plate 7. An interpretation of the correlation between the Cutler formation exposed along the Green and Colorado Rivers and the Kaibab limestone and Coconino sandstone of the San Rafael Swell is shown in plate 8.

\section{CEDAR MESA SANDSTONE MEMBER}

The Cedar Mesa sandstone member of the Cutler formation crops out along the canyon of Green River below the mouth of Horse Canyon and along the Colorado River from the mouth of the Green to the mouth of the Dirty Devil River; it dips below the Colorado River about 2 miles south of the mouth of the Dirty Devil River. It also extends about 10 miles up the canyon of the Dirty Devil, where it forms a shallow, nearly verticallywalled inner gorge. The lower part of the member forms a vertical cliff 50 to 100 feet high at the rim of the canyon of the Green River near its mouth and along most of Cataract Canyon. (See pl. 6, A.) Near the lower end of Cataract Canyon, in the vicinity of the mouth of Dark Canyon and Mille Crag Bend, practically the entire thickness of the Cedar Mesa sandstone

${ }^{20}$ Baker, A. A., Geology of the Monument Valley-Navajo Mountain region, San Juan County, Utah: U. S. Geol. Survey Bull. 865, pp. 29-37, 1936. 
member crops out in the steep canyon walls (p. $5, B$ ), and forms a bench or platform extending back from the canyon rims. In the southern part of the area the platform, which is only about a mile wide and is essentially coincident with the top of the sandstone, is a relatively smooth plain trenched by a few canyons; in some places the plain is covered with soil and vegetation and in others it has a bare-rock surface. Toward the north the platform widens and reaches a maximum width of about 7 miles opposite the junction of the Green and Colorado Rivers. In its widest,parts the surface of the platform is a series of cliffs, mesas, buttes, spires, and steep-walled canyons that provide an unusual scenic effect, and it is so rugged that parts of it cannot be traversed even on foot. (See pls. 6, $A, B, 9, A$.) Erosion of the sandstone into innumerable spires has been controlled in part by abundant joints and faults. At many places in the vicinity of Cataract Canyon pot holes or tanks in the Cedar Mesa sandstone contain rain water and are an important source of water.

The Cedar Mesa sandstone changes in lithology across the area of its outcrop in the Green River Desert-Cataract Canyon region. In the greater part of its outcrop it is a friable, light-gray to very light-tan, fine- to coarse-grained sandstone consisting almost entirely of angular to rounded quartz grains, many of which have a frosted surface. The principal cementing material is calcium carbonate, although many of the sand grains are coated with secondary silica. The sandstone is thick-bedded and is tangentially cross-bedded, with the cross bedding dipping dominantly toward the southeast. Rarely it contains thin lenticular beds of red siltstone. The upper part of the sandstone is petroliferous at several localities. In the northern part of its outcrop the Cedar Mesa sandstone is less massive and toward the north contains progressively more interbedded red sediments, ranging from shale and siltstone to arkose and quartz sandstone. (See pl. 9, B.) The change in lithology occurs as intertonguing of more or less typically light-colored Cedar Mesa sandstone with red beds and by lateral gradation from light-colored quartz sandstone to red beds. The gradation occurs through sandstone containing mica and feldspar to sandstone faintly tinted pink, to red sandstone, and finally to a deep red or maroon arkose or siltstone. In the vicinity of the mouth of Horse Canyon the Cedar Mesa sandstone has changed almost completely to red rocks practically identical in lithology and inseparable from the overlying Organ Rock tongue of the Cutler formation. Most of the change from light-gray or tan sandstone to red beds occurs in a distance of about 10 miles south of the mouth of Horse Canyon. The thickness of the Cedar Mesa sandstone is 747 feet where it was measured between the 
head of Spanish Trail and Standing Rock, and it is 700 feet thick about 10 miles east of the junction of the Green and Colorado Rivers. $^{30}$ The following section shows the lithology of the Cedar Mesa sandstone in the northern part of its outcrop.

Section of the Cedar Mesa sandstone member of the Cutler formation measured along trail from top of Spanish Trail to Standing Rock

Organ Rock tongue of Cutler formation.

Cedar Mesa sandstone member of Cutler formation:

Sandstone, white and lavender, interbedded, thick-bedded, massive

Sandstone, white, cross-bedded, weathers into ledges, contains numerous local lenses of red sandy shale and lavender sandstone...... , 100

Shale, red, sandy, interbedded with yellow and white sandstone, thin and irregularly bedded.

Sandstone, red, silty, and shale, red

Sandstone, white, cross-bedded, with few beds of red shale.................. 44

Sandstone, white to pink, cross-bedded ..................................................... 57

Sandstone, red

Shale, red, nodular, limy

Sandstone, lavender, coarse-grained, arkosic.

Sandstone, brownish red, cross-bedded.

Sandstone, massive, white, upper part grades laterally into red sandstone

Shale, red, sandy, with thin sandy limestone.

Sandstone, white, massive................................................................................. 18

Shale, red, sandy, and sandstone, purplish _............................................... 6

Sandstone, white, massive................................................................... 44

Limestone, gray to lavender......................................................... $1 / 2$

Sandstone, red to purple, thick-bedded........................................................... 49

Sandstone, white, cross-bedded, with few lenses of red shale................ 121

Shale, red, with thin local lens of steel-gray limestone

Sandstone, white, cross-bedded ……........................................... 8

Shale, red ................................................................................................... 1

Limestone (local lens), steel-gray, cherty, unfossiliferous.................. 1

Sandstone, white, cross-bedded, medium- to coarse-grained............... 49

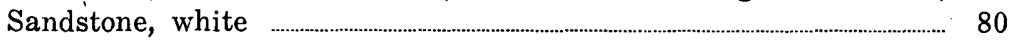

Rico formation.

The Cedar Mesa sandstone conformably overlies the Rico formation, which contains Permian fossils. At its upper contact the overlying Organ Rock tongue of the Cutler formation locally rests upon an irregularly channeled surface of the sandstone, but at other localities the contact is not well defined and the light-gray or light-tan sandstone grades upward into the silty red sandstone of the Organ Rock tongue. Toward the south the Cedar Mesa sandstone crops out continuously between Cataract Canyon and

${ }^{30}$ Baker, A. A., Geology and oil possibilities of the Moab district, Grand and San Juan Counties, Utah: U. S. Geol. Survey Bull. 841, p. 31, 1933. 
the type locality of the member at Cedar Mesa near the San Juan River in southern Utah. ${ }^{31}$

The Cedar Mesa sandstone was formerly called the Coconino sandston $e^{32}$ and was correlated directly with the Coconino sandstone of the Grand Canyon region. Recent regional studies have shown that it is undoubtedly continuous with the Coconino sandstone of the San Rafael Swell, Circle Cliffs, and Grand Canyon ${ }^{33}$ but that it appears to be only the lower of two eastward-extending tongues of the massive Coconino sandstone present at those localities..$^{34}$

The thick-bedded, tangentially cross-bedded, light-colored sandstone of the Cedar Mesa was probably in part deposited by wind, although well-defined bedding planes and occasional lenses of red siltstone indicate some water transportation and sorting. Regional relationships show that the sandstone loses its identity toward the southeast, which suggests, when considered in conjunction with a dominant southeasterly dip of cross-bedding planes, that the source of the material was toward the northwest, and that movement of material was toward the southeast. In the northern part of its area of outcrop the sandstone intertongues with and grades laterally into red beds whose arkosic character, increase in coarseness of grain toward Colorado, and irregular bedding undoubtedly indicate fluviatile deposition of material transported from ancient highlands of crystalline rocks in western Colorado. During Cedar Mesa time, therefore, the Green River region appears to have received water-borne red sediments from the east and wind-borne white sand from the northwest with a certain amount of intermingling of the two types of sediments.

\section{ORGAN ROCK TONGUE}

The Organ Rock tongue of the Cutler formation crops out only in the southern part of the region. It rises above the level of Green River about 2 miles south of the mouth of Millard Canyon and crops out along the canyon walls to the mouth of Horse Canyon, where the belt of outcrop swings southwestward more

\footnotetext{
${ }^{31}$ Gregory, H. E., The San Juan country a geographic and geologic reconnaissance of southeastern Utah: U. S. Geol. Survey Prof. Paper 188, p. 43, 1938; Baker, A. A., and Reeside, J. B., Jr., Correlation of the Permian of southern Utah, northern Arizona, northwestern New Mexico, and southwestern Colorado: Am. Assoc. Petroleum Geologists Bull., vol. 13, p. 1443, 1929.

$\$ z$ Longwell, C. R., Miser, H. D., Moore, R. C., Bryan, Kirk, and Paige, Sidney. Rock formations in the Colorado Plateau of southeastern Utah and northern Arizona: U. S. Geol. Survey Prof. Paper 132, p. 8, 1923.

${ }^{33}$ Gregory, H. E., and Moore, R. C., The Kaiparowits region, a geographic and geologic reconnaissance of parts of Utah and Arizona: U. S. Geol. Survey Prof. Paper 164, pp. 38-45, 1931. Noble, L. F., A section of the Paleozoic formations of the Grand Canyon at the Bass Trail: U. S. Geol. Survey Prof. Paper 131, pp. 66-68, 1923.

${ }^{34}$ Baker, A. A., and Reeside, J. B., Jr., Correlation of the Permian of southern Utah, northern Arizona, northern New Mexico, and southwestern Colorado: Am. Assoc. Petroleum Geologists Bull., vol. 13, pp. 1413-1448, 1929.
} 
or less parallel to the Colorado River and extends to the mouth of the Dirty Devil River; it crops out in the walls of the canyon of the Dirty Devil River and dips below river level about 12 miles above the mouth. The Organ Rock tongue crops out in steep slopes or cliffs, which border the wide platform of the Cedar Mesa sandstone. (See pls. 10, $A, B$.) The cliffs or steep slopes merge at the top at most places with the vertical cliff formed by the overlying White Rim sandstone member of the Cutler. A few isolated steep-sided mesas or tall slender spires, such as Candlestick Spire and Standing Rock, formed by the Organ Rock tongue rise high above the platform of the Cedar Mesa sandstone and are unusual scenic features of the region. (See pls. 9, $A, 11, A$.)

The Organ Rock tongue consists typically of red siltstone, silty sandstones, and some beds of red sandy shale. Toward the north end of its outcrop, especially in the lower part of the tongue, which is laterally equivalent to the Cedar Mesa sandstone, the Organ Rock contains much arkosic material. At many localities the upper few feet of the Organ Rock tongue have been bleached to a light tan, possibly because of partial reduction of the iron oxide in the red sediments by water percolating downward from the overlying petroliferous White Rim sandstone. The Organ Rock tongue in most places is regularly bedded in beds a few inches to a few feet thick and weathers into a horizontally fluted surface as a result of deeper etching of the bedding planes. A knobby or bouldery, fluted surface is a distinctive feature of outcrops of the Organ Rock tongue. At the mouth of the Dirty Devil River the Organ Rock tongue contains a bed of fine- to coarse-grained, cross-bedded purplish-red to salmon-pink arkosic sandstone 50 feet thick, the top of which is 132 feet below the top of the Organ Rock tongue. (See pl. 10, B.) Upstream along the Dirty Devil River this sandstone becomes lighter colored and is similar in lithology to the White Rim sandstone; at the mouth of Hatch Canyon the Organ Rock beds between these two sandstones are only about 30 feet thick and the lower sandstone was there mapped as part of the White Rim. The following sections illustrate typical Organ Rock lithology:

Section of Organ Rock tongue of Cutler formation at entrance to upper Cove Canyon 3 miles southwest of Red Point

White Rim sandstone member of the Cutler formation: Sandstone, gray to

buff cross-bedded, coarse-grained; forms sheer cliff.

Organ Rock tongue of the Cutler formation:

Sandstone, silty, greenish-gray, fine-grained

Sandstone, silty, gray with red splotches, nodular-weathering ......... 18

Sandstone, silty red... 
Sandstone, light-gray, fine-grained, contains many red quartz grains, ledge-forming.

Sandstone, silty red and sandy red shale grading into overlying sandstone

Sandstone, buff, medium-grained, ledge-forming, grades into overlying unit.

Siltstone and sandy shale, red, thin, regularly bedded, nodularweathering, interbedded with fine-grained reddish-brown sandstone

Shale, sandy, and fine-grained limy sandstone, greenish-gray

Cedar Mesa sandstone member of the Cutler formation: Sandstone, light gray, cross-bedded, medium-grained, petroliferous, contains nodules of crystalline calcite.

Section of Organ Rock tongue of Cutler formation neasured along trail on east side of ridge between Elaterite Basin and the East Fork of Horse Canyon

Moenkopi formation: Shale, red, with numerous thin beds of red to gray sandstone.

Organ Rock tongue of Cutler formation:

Sandstone, red, medium- to fine-grained, silty, nodular-weathering

Sandstone, red to gray, medium-grained, silty; (grades laterally into gray sandstone of the White Rim sandstone member of the Cutler north of this locality)

Sandstone, purplish-brown, and red, massive, more or less arkosic, silty; forms smooth bedrock slopes.

Sandstone and siltstone, red, fine-grained; weathers in nodular and fluted surfaces

Sandstone, red to salmon, silty, micaceous, massive in thick beds; gradational contact with underlying gray to buff sandstone.

Cedar Mesa sandstone member of the Cutler formation.

Variations in thickness along the belt of outcrop are shown graphically in plate 7. On the Dirty Devil River 6 miles above its mouth the Organ Rock tongue is 395 feet thick. The thickness, which is 345 feet at the mouth of the Dirty Devil River, decreases progressively northeastward to the minimum observed thickness of $\mathbf{1 1 7}$ feet measured along the trail across the cliff at the head of Range Canyon. Northeast of Range Canyon the thickness increases to 235 feet about 1 mile above the mouth of the East Fork of Horse Canyon. In lower Horse Canyon and northwestward along the canyon of Green River the Organ Rock tongue increases rapidly in thickness as the underlying gray sandstone of the Cedar Mesa member grades northwestward into red beds of Organ Rock lithology. About 2 miles northwest of the mouth of Horse Canyon the Organ Rock tongue is about 870 feet thick and includes all the Cutler formation except the thin overlying White Rim sandstone member. 
s.

$\leftarrow \quad 12$ miles

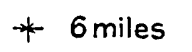

* 7 miles $+7 \frac{1}{2}$ miles

+5 miles +3 mi. $+11 / 2$ mil/2mi 4 miles $-\frac{\$}{10}$ miles +5 miles +6 miles $\rightarrow$

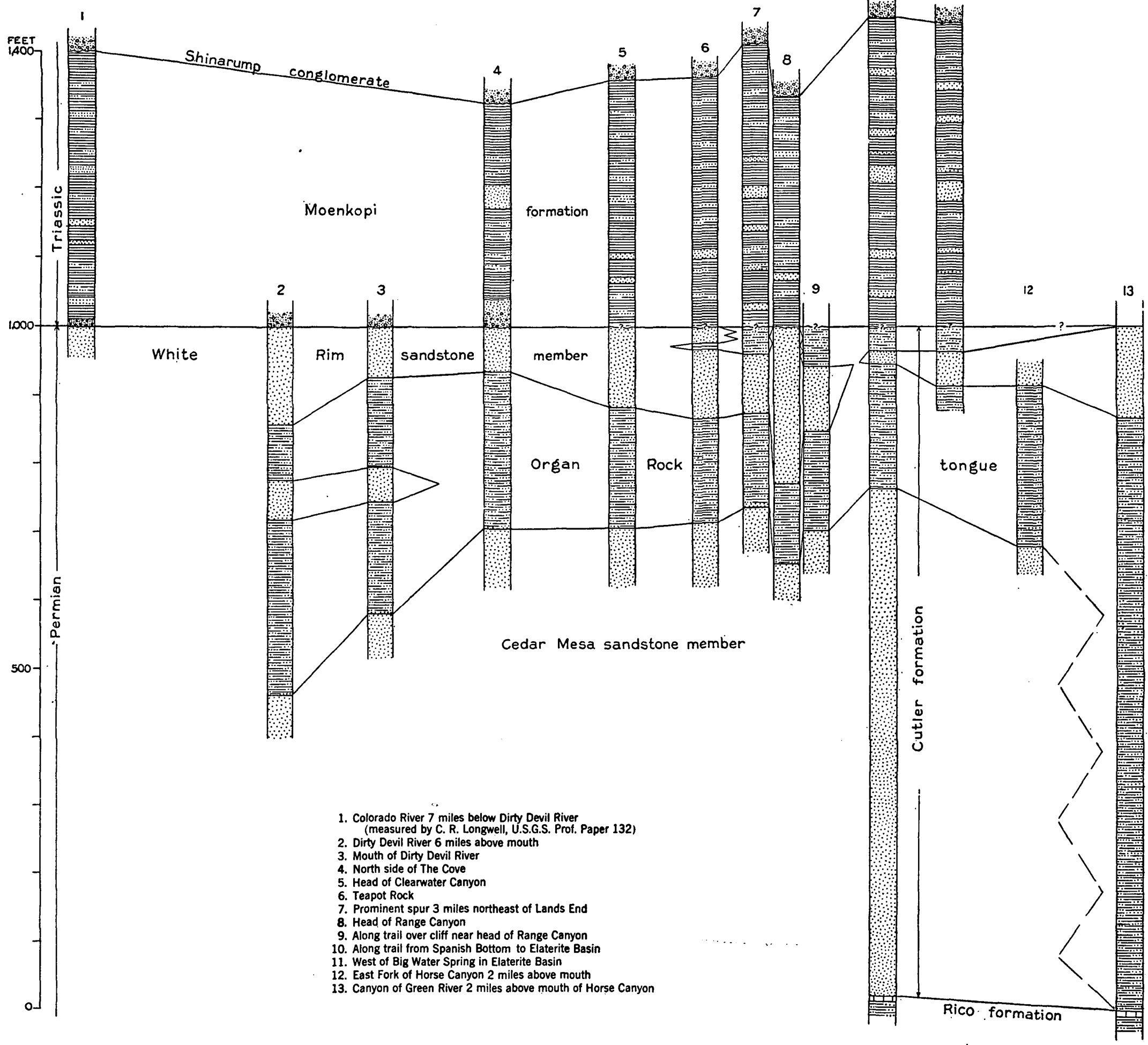

SECTIONS SHOWING LATERAL VARIATIONS OF CUTLER AND MOENKOPI FORMATIONS ALONG CANYONS OF THE GREEN AND COLORADO RIVERS. 
At some localities the surface of the Cedar Mesa sandstone upon which the Organ Rock tongue was deposited shows considerable local relief and the contact between the light-gray sandstone and the red silty sandstone is sharp, but at other localities the contact is gradational, and it is difficult to select an exact boundary. Similar conditions exist at the contact between the Organ Rock tongue and the overlying White Rim sandstone. The local relief and the sharp contacts have little significance, however, as an indication of a time break or hiatus at those horizons, in view of the intimate relations of the Organ Rock tongue to the enclosing sandstones. In Green River Canyon the Cedar Mesa sandstone grades into Organ Rock beds, and along the Dirty Devil River the Organ Rock tongue grades upstream into rocks of White Rim type. The thickness of the Organ Rock tongue changes rapidly; decreases in thickness are associated, at least in part, with increases in the thickness of the overlying White Rim and, possibly also in part, with increases in the thickness of the Cedar Mesa, although the relationship there is less clear. These relationships might be attributed to considerable regional relief of the Cedar Mesa surface at the time the Organ Rock tongue was deposited upon it and of the Organ Rock surface at the time the White Rim was deposited upon it. However, it seems more probable, because of the intertonguing relationships of these units, as described above, that the changes in thickness are due to changes in facies and that the silty sands of the Organ Rock tongue were being 'deposited at some localities at the time that the light-colored sands of the Cedar Mesa were being deposited at other localities. Similarly, the time of deposition of the Organ Rock probably was contemporaneous, in part, with the time of deposition of the White Rim at other localities.

The Organ Rock tongue, where it overlies the Cedar Mesa sandstone, is in the same stratigraphic position and is equivalent to the $\nmid$ Bogus tongue ${ }^{35}$ of the Cutler formation east of the Colorado River, which was named and described in a report on the Moab district. ${ }^{36}$ The name Bogus as applied to this stratigraphic unit is here abandoned in favor of the name Organ Rock, as it is now evident through more recent work ${ }^{3 i}$ that the red beds formerly included in the Bogus are continuous with the Organ Rock tongue at its type locality near Organ Rock south of the San Juan River

\footnotetext{
${ }^{85}$ A dagger ( $\dagger$ ) preceding a geologic name indicates that the name has been abandoned or rejected for use in classification in publications of the Geological Survey.

${ }^{36}$ Baker, A. A., Geology and oil possibilities of the Moab district, Grand and San Juan Counties, Utah: U. S. Geol. Survey Bull. 841, pp. 30-32, 1933.

${ }^{37}$ Gregory. H. E., The San Juan country, a geographic and geologic reconnaissance of northeastern Utah: U. S. Geol. Survey Prof. Paper 188, p. 46, 1938. Baker, A. A., Geology of the Monument Valley-Navajo Mountain region, San Juan County, Utah: U. S. Geol. Survey Bull. 865, pp. 33-35, 1936.
}

$697241 .-46-4$ 
in southern Utah. Eastward from the Green River DesertCataract Canyon region the Organ Rock tongue includes more and more of the Cutler formation until it coincides with the entire Cutler in the Moab district. Toward the west and northwest, as shown on plate 8 , the Organ Rock tongue disappears, probably by lateral transition into the white Coconino sandstone as exposed in the San Rafael Swell and the Kaiparowits region. ${ }^{38}$

Between the Colorado-Utah State line and the Green River Desert-Cataract Canyon region the Cutler formation consists of coarse-grained to conglomeratic, irregularly bedded arkosic sediments, which become finer-grained toward the west. ${ }^{39}$ There is little doubt that pre-Cambrian crystalline rocks in western Colorado were the source of the sediments that were carried westward by streams and deposited upon an aggrading plain. The relatively thin regular bedding and dominance of relatively finegrained sediments typical of the Organ Rock tongue in the Green River Desert-Cataract Canyon region appear to represent the finer material that the streams were able to transport farthest from the highland source and that was deposited upon nearly flat aggraded plains as the transporting capacity of the streams diminished due to decrease in gradient or decrease in.volume of water.

WHITE RIM SANDSTONE MEMBER

The name White Rim has long been applied by local residents to a prominent cliff formed by a sandstone bed along the lower part of the canyon of Green River and on the west side of the canyon of the Colorado River. This sandstone, which is the upper of the two light-colored sandstone units in the Cutler formation of the region, was therefore designated the White Rim sandstone member of the Cutler formation. ${ }^{40}$

The White Rim sandstone crops out in the southern part of the Green River Desert-Cataract Canyon Region. It rises above water level on Green River about 2 miles downstream from Fort Bottom and crops out in a narrow belt extending south and southwest to the mouth of the Dirty Devil River; it crops out in the walls of the canyon of the Dirty Devil River and dips below water level

\footnotetext{
${ }^{38}$ Baker, A. A., and Reeside, J. B., Jr., Correlation of the Permian of southern Utah, northern Arizona, northwestern New Mexico, and southwestern Colorado: Am. Assoc. Petroleum Geologists Bull., vol. 13, pp. 1413-1448, 1929.

${ }^{39}$ Dane, C. H., Geology of the Salt Valley anticline and adjacent areas, Grand County, Utah: U. S. Geol. Survey Bull. 863 , pp. 38-41, 1935. Baker, A. A., Geology and oil possibilities of the Moab district, Grand and San Juan Counties, Utah: U. S. Geol. Survey Bull. 841, pp. 29-33, 1933. McKnight, E. T., Geology of area between Green and Colorado Rivers, Grand and San Juan Counties, Utah: U. S. Geol. Survey Bull. 908, 1940 [1941].

${ }^{40}$ Bakers, A. A., and Reeside, J. B., Jr., Correlation of the Permian of southern Utah, northern Arizona, northwestern New Mexico, and southwestern Colorado: Am. Assoc. Petroleum Geologists Bull., Vol. 13, p. 1444, 1929.
} 
about 20 miles above the mouth of the river. Along Horse Canyon and the canyon of Green River above the mouth of Horse Canyon, the White Rim sandstone forms the vertical upper walls of an inner gorge cut below a broad bench. (See pls. 11, C, 12, B.) Locally the bench is formed by the upper surface of the White Rim sandstone, but the greater part of the bench is formed by a thin mantle of soft red sandstone and shale of the overlying IMoenkopi formation. Between Elaterite Butte and Teapot Rock the White Rim sandstone crops out in a cliff or steep slope, which forms a conspicuous gray band except for a distance of about 3 miles where it is absent. The White Rim does not form a prominent bench in this part of the area. Southwest of Teapot Rock and along the Dirty Devil River it also crops out in a practically impassable cliff, which rims a broad bench that is nearly everywhere covered with a relatively thin mantle of younger rocks. The White Rim sandstone is the rim rock of an inner canyon through which the Dirty Devil River flows near its mouth. At many places, the normally red rocks above and below the White Rim are bleached to tan or gray and tend to cause a false impression of greater thickness of the sandstone.

In lithology and in general appearance the White Rim sandstone is similar to the Cedar Mesa sandstone member. It is highly cross-bedded with both tangential and angular types of bedding and is normally light gray but locally contains tan to buff beds. It consists predominantly of medium to coarse quartz grains ; most of the grains are well rounded with a frosted surface, but some are subrounded to angular. Many of the grains have a coating of secondary quartz crystals, but the principal cementing material is calcium carbonate. At many places the White Rim sandstone is more or less saturated with petroleum, and there is seepage of a tarry petroleum residue from this sandstone in Elaterite Basin about a mile south of Big Water Spring.

As shown on plate 7 , there is considerable variation in the thickness of the White Rim sandstone. The maximum observed thickness is 230 feet measured at the head of Range canyon, but only 2 miles north of that locality the sandstone is absent or at most is a very thin unit so lithologically similar to the enclosing rocks that it cannot be distinguished from them. The White Rim is 145 feet thick on the Dirty Devil River about 6 miles above the mouth and is somewhat thicker farther upstream. At the mouth of the Dirty Devil River it is about 75 feet thick, and in the Cove it is about 65 feet thick. Northeast of the Cove it increases in thickness more or less irregularly to the maximum of 230 feet measured at the head of Range Canyon. It is very thin or absent for a distance of about 3 miles north of the Wayne-Garfield County 
line but reappears in the vicinity of the trail from Elaterite Basin to Spanish Bottom. It increases in thickness toward the northeast to about 135 feet on Green River, 2 miles above the mouth of Horse Canyon.

At the base the White Rim sandstone grades both downward and laterally into the red siltstone of the Organ Rock tongue. At most localities there is a thin series of beds that are gradational between the two lithologic types. The lateral gradation into rocks of the Organ Rock type of lithology is well displayed where the White Rim sandstone thins and disappears in southern Wayne County. At that locality the light-gray sandstone of the White Rim grades laterally into yellow and salmon-pink sandstone, then into silty red sandstone recognizable as a continuation of the same ledge, and finally into siltstone that cannot be distinguished from rocks of Organ Rock lithology. Lateral gradation also is evident along the Dirty Devil River. In a distance of about 6 miles upstream from the mouth, the White Rim increases in thickness from 75 to 145 feet as the red beds separating the White Rim from a light-colored sandstone in the Organ Rock tongue (see p. 41) decrease in thickness by a similar. amount. The red beds are 130 feet thick near the mouth of the Dirty Devil River but are represented by a thickness of about 30 feet at the upstream limit of the outcrop near the mouth of Hatch Canyon. Although these rocks dip below stream level in the vicinity of the mouth of Hatch Canyon, it seemed obvious that, a short distance farther upstream, the red beds would be expected to wedge out, and the lower sandstone would be inseparable from the White Rim sandstone. Similarly, throughout its outcrop, thickening of the White Rim is, in part at least, offset by thinning of the underlying Organ Rock, which, if considered in connection with the general gradational character of the contact, also is suggestive of lateral gradation.

The upper contact in the southern part of the area is marked by an unconformity at the base of a thin conglomerate of the Moenkopi formation, which rests directly upon the White Rim sandstone. The Moenkopi formation also unconformably overlies the White Rim sandstone at the head of Range Canyon where approximately 80 feet of the basal Moenkopi is cut out by overlap against locally thickened White Rim. (See pl. 10, A.) At most places north of the Cove the White Rim is overlain by a thin series of red siltstone, identical in lithology with the siltstone of the Organ Rock and therefore included in the Cutler formation. These red beds were not drawn on the map (pl. 1) as a separate stratigraphic unit; where recognized in the field they were mapped with the White Rim.sandstone. No unconformity was 
recognized between this series of red beds and the overlying red shale and sandstone of the Triassic Moenkopi formation, but the unconformity observed near the mouth of the Dirty Devil River and at the head of Range Canyon probably is present at that horizon. The red beds overlying the White Rim sandstone and included in the Cutler formation are 40 feet thick on the prominent cliff spur 3 miles northeast of Lands End but appear to be cut out by overlap against the unusually thick White Rim sandstone at the head of Range Canyon. The upper beds are quite sandy and bleached to tan along the trail over the cliffs near the head of Range Canyon, where they are 60 feet thick. They are 35 feet thick near Big Water Spring in Elaterite Basin. These beds probably are present farther north along Green River, but they were not differentiated from the overlying Moenkopi formation. The variation in the thickness of the upper red beds probably is due in large part to local relief upon the upper surface of the White Rim sandstone; at the head of Range Canyon the local relief is more than 100 feet in less than a mile, and in the canyon of Big Water there is local relief upon this surface of 30 feet or more in a distance of about 200 feet. The relief probably represents irregularities of the upper surface of the sand at the time of accumulation, rather than irregularities produced during a period of erosion prior to the deposition of the overlying red beds.

The regional stratigraphic relationships of the White Rim are shown in part on plate 8 . This sandstone is absent east of the Colorado River ${ }^{41}$ at localities LC and IC. West and northwest from the belt of outcrops along the Green and Colorado Rivers the White Rim sandstone probably merges with the upper part of the Coconino sandstone, which crops out in the San Rafael Swell and the Circle Cliffs. However, it may not be continuous across the northern part of the area, as shown on plate 8 . The White Rim sandstone probably is at approximately the same horizon as the DeChelly sandstone member of the Cutler formation, which crops out near the San Juan River in southern Utah and is of similar lithology. It is perhaps significant that in that region the DeChelly sandstone is overlain by the thin Hoskinnini tongue of the Cutler, which consists of red siltstone of Organ Rock type. ${ }^{42}$ Although the stratigraphic equivalence of these two sandstone members of the Cutler formation seems probable, it is deemed inadvisable to apply the same name to them because of the absence of sandstones of typical DeChelly or White Rim lithology

\footnotetext{
${ }^{41}$ Baker, A. A., Geology and oil possibilities of the Moab district, Grand and San Juan Counties, Utah: U. S. Geol. Survey Bull. 841, pp. 29-33, 1933.

${ }^{42}$ Baker, A. A., Geology of the Monument Valley-Navajo Mountain region, San Juan County, Utah: U. S. Geol. Survey Bull. 865, pp. 35-40, 1936.
} 
at this horizon in the intervening area and the consequent impossibility of establishing lithologic continuity or precise equivalence.

The eastward thinning and eventual disappearance of the White Rim by lateral gradation and intertonguing with red sediments is suggestive of a western source of the material in contrast with a known eastern source for the red beds in western Colorado. Although numerous horizontal bedding planes seem to indicate that at least part of the sandstone was deposited in water, the writer is inclined to believe that the highly cross-bedded sandstone is dominantly wind-laid. The water-laid red beds of the Cutler were deposited by westward-flowing streams at the time that the light-gray quartz sands of the White Rim were being deposited farther west. If the gray sands were deposited in a large body of water, such as the ocean or a large lake, it seems obvious that the red sediment in westward-flowing streams would have been emptied into the body of water and that considerable red material would be mixed with the light-colored sands. On the contrary, there is a fairly abrupt change in lithology from red siltstone to light-gray quartz sandstone, and at a very short distance from the zone of change the light-gray sandstone contains no intermixture of red material. These conditions are consistent with a theory that the light-colored sands were transported and deposited by winds from the west and that the red sediments were transported by westward-flowing streams that probably extended only to about the border of, the sand-covered area. The top of the unusually thick White Rim sandstone at the head of Range Canyon (pl. 10, A) projects above the level of the top of the Cutler formation at neighboring exposures and may represent a dune that was not completely beveled before overlying sediments were deposited. Similarly local relief upon the top of the White Rim as observed in Big Water is interpreted as a "fossil" sand dune.

\section{COCONINO SANDSTONE}

The Coconino sandstone crops out only in the northwestern part of the Green River Desert-Cataract Canyon region in the San Rafael Swell. It is the surface rock in large areas near the crest and on the east flank of the Swell. The surface of much of the areas floored by the Coconino sandstone approximately coincides with the top of the sandstone; the curvature of these dip slopes is convex upward and reflects the shape of the huge structural arch of the Swell. (See pls. 14 and 16.) Many canyons in the steep east flank of the Swell have been cut into the Coconino sandstone. All these canyons have very steep, rugged walls and most of them are very narrow at the bottom. Practically 
all the canyon beds cross this sandstone in a series of unscalable falls or "jumps". This sandstone is an important source of water in its area of outcrop as rain water accumulates in numerous depressions, particularly under the falls in the drainage courses. The larger pools contain potable water for long periods and in many large areas constitute the only water supply.

The Coconino sandstone is thick-bedded and highly cross-bedded. The cross bedding is on a large scale and of both tangential and angular type. Fresh rock surfaces are light gray to buff with numerous more or less irregular patchés of red, but weathered surfaces commonly have a nearly black coating of desert "varnish" which gives a somber appearance to outcrops of this sandstone in distant view. The sandstone consists principally of quartz of medium to coarse grain cemented with calcium carbonate. The grains are rounded to subangular and many of them have a frosted surface. Some beds contain abundant feldspar and mica. Locally, - as in the canyon of Straight Wash, the upper part of the Coconino is more or less saturated with petroleum residue.

The base of the Coconino sandstone is exposed in the San Rafael Swell only in the canyon of the San Rafael River, a few miles west of the area described in this report, and in the canyon of Straight Wash. The thickness of the Coconino was not measured in Straight Wash, but as measured by Gilluly ${ }^{43}$ in The Black Box of the San Rafael River it is 711 feet thick. However, he included 26 feet of interbedded limestone and sandstone at the base that seems unquestionably to be equivalent to part of the older rocks exposed in Straight Wash (p. 30); possibly the lower 51 feet of Gilluly's section should be included with the older rocks, because his descriptions show that the lithology is somewhat different from that of the rest of the formation.

The base of the Coconino sandstone appears to be conformable with the underlying rocks where examined in the canyon of Straight Wash and, as described by Gilluly, in the canyon of the San Rafael River, but if the tentative assignment of these older rocks to the Hermosa is correct there should be a hiatus at the base of the Coconino equivalent at least to the duration of Rico time. The fossiliferous Kaibab,limestone of Permian age appears to be conformable upon the Coconino sandstone. At some places the contact is gradational through a zone 1 to 10 feet thick consisting of limy sandstone with small chert concretions.

No fossils were found in the Coconino sandstone of this region but it is correlated with the type Coconino sandstone of Permian age on the basis of its lithology and its stratigraphic relationship

${ }^{43}$ Gilluly, James, Geology and oil and gas prospects of part of the San Rafael Swell, Utah: U. S. Geol. Survey Bull. 806, pp. 80-81, 1929. 
to the overlying Kaibab limestone. As shown in plate 8 , the Coconino sandstone of the San Rafael Swell is interpreted to be the lateral equivalent of the Cutler formation exposed in the canyons of the Green and Colorado Rivers. The Cutler formation is underlain by the Permian Rico formation. Areas in which the Coconino sandstone and the Kaibab limestone are concealed beneath younger rocks prevent tracing of these rock units between the San Rafael Swell and the type locality at Grand Canyon, Ariz., but the presence of these rock types in typical association at the intervening localities of Lees Ferry, Ariz., and the Circle Cliffs, Utah, ${ }^{44}$ leaves no question of the essential continuity of the lithologic units.

The conditions of deposition of the Coconino sandstone probably were the same as the conditions under which the tongues of this sandstone represented by the White Rim and Cedar Mesa sandstone members of the Cutler formation were deposited. As described on preceding pages, the sands that make up these sandstones were probably derived from a western source and are considered to be dominantly wind-laid.

\section{KAIBAB LIMESTONE}

The Kaibab limestone overlies the Coconino sandstone and crops out extensively near the crest and on the east flank of the San Rafael Swell. It forms a blocky ledge and wide dip slopes from which the less resistant rocks of the overlying Moenkopi formation have been stripped.

The limestone of the Kaibab is commonly sandy and locally grades into limy sandstone. It is light gray to brown but weathers yellowish brown. Chert geodes 2 to 3 inches in diameter, which are numerous, are lined with quartz and calcite crystals, and many of them contain asphaltic material. Fossil shells of marine organisms are abundant locally in the limestone. The thickness of the Kaibab limestone is very irregular. The maximum observed thickness is $\mathbf{1 0 2}$ feet measured about 6 miles west of Temple Mountain, but the Kaibab is absent in a large area near the head of Ștraight Wash and in other smaller areas where the Moonloppi formation rests upon the Coconino sandstone. Other measured thicknesses of the limestone are 30 feet at a locality 1 mile north of Temple Mountain, 50 feet where Straight Wash crosses the Reef, and 70 feet about 3 miles north of Straight Wash.

The following section of the Kaibab limestone, which was measured near Temple Mountain, illustrates the lithology of the formation.

\footnotetext{
14 Gregory, H. E., and Moore, R. C., The Kaiparowits region, a geographic and geologic reconnaissance of parts of Utah and Arizona: U. S. Geol. Survey Prof. Paper 164, pp. 38-45, 1931.
} 


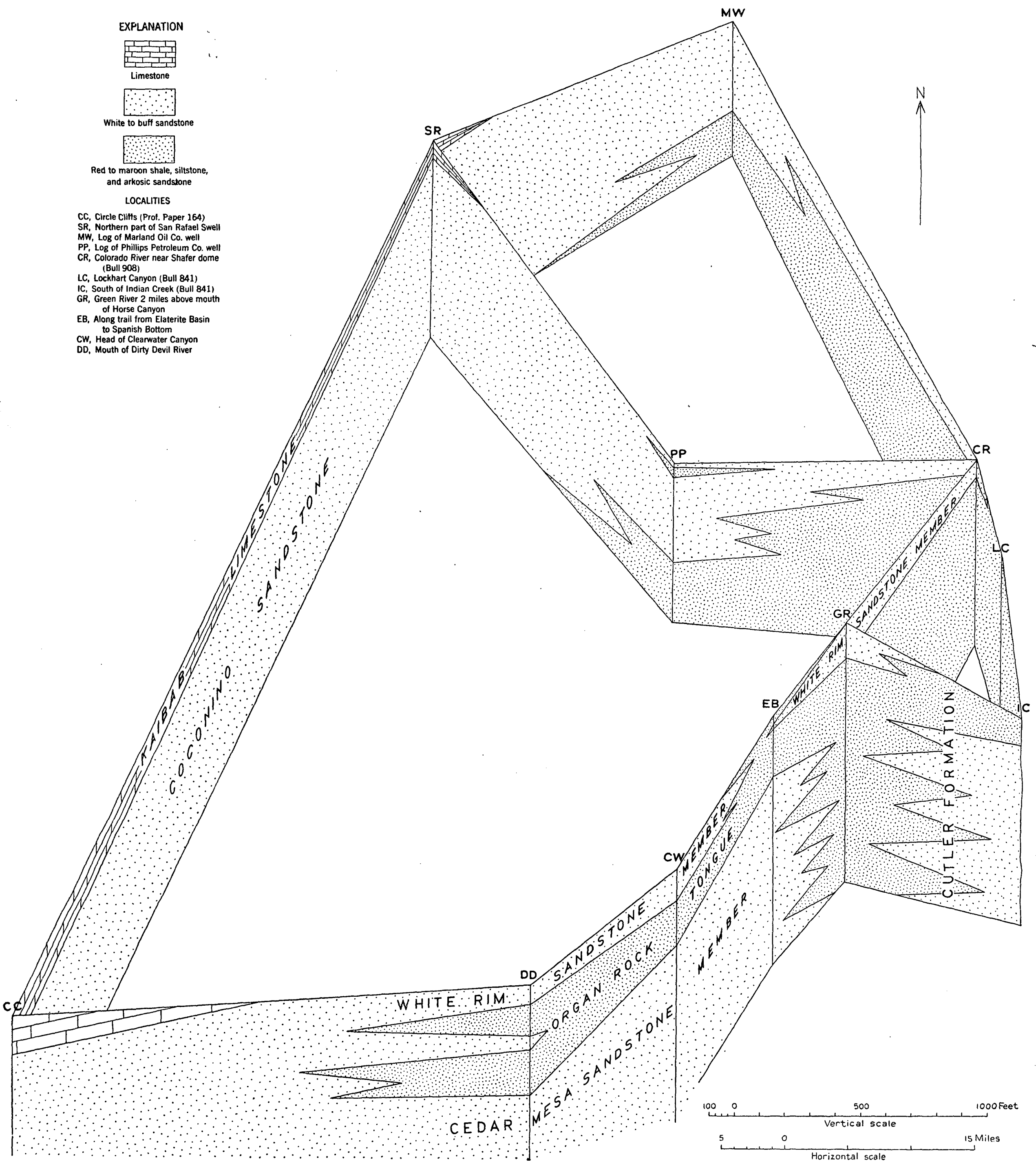

DIAGRAM SHOWING INTERPRETATION OF THE CORRELATION OF THE CUTLER FORMATION EXPOSED ALONG THE GREEN AND COLORADO RIVERS WITH THE KAIBAB LIMESTONE AND COCONINO SANDSTONE OF SAN RAFAEL SWELL AND CIRCLE CLIFFS, UTAH. 
Section of the Kaibab limestone one mile north of Temple Mountain [Measured by M. M. Knechtel]

Moenkopi formation.

Unconformity.

Kaibab limestone:

I imestone, light-gray to buff in thick beds weathering with rounded edges and honeycombed surface; contains occasional chert geodes

Limestone, dark-gray, sandy.

Limestone, light-gray, sandy, hard, thick-bedded, fossiliferous; contains abundant chert geodes with a maximum diameter of about 2 inches.

Sandstone, gray, limy, and limestone, gray, sandy, fossiliferous........

Shale, green, gypsiferous, fossiliferous, contains few small rounded quartz grains.

Coconino sandstone.

The Kaibab is separated from the overlying Triassic Moenkopi formation by an unconformity, which is marked by a channeled surface and by a basal Moenkopi conglomerate containing pebbles and boulders of Kaibab material. Erosion of the Kaibab limestone before the Moenkopi was deposited resulted in the removal of part of or all the Kaibab in some areas and is the principal cause of the irregular variations in the thickness of the limestone. Regional relief at the base of the Moenkopi in the San Rafael Swell is equal to the maximum thickness of 102 feet of the Kaibab and may be somewhat greater, but it is impossible to determine the amount of the underlying Coconino sandstone that may have been removed by pre-Moenkopi erosion in the areas where the Kaibab is absent. Local relief of 40 feet within a distance of less than a mile along the outcrop was observed about a mile south of the well of the Carter Oil Co.

Fossils collected from the Kaibab limestone by Gilluly near the Lockhart Cabins on the San Rafael River about 6 miles northwest of the northwest corner of T. 22 S., R. 13 E., were studied by G. H. Girty, who made the following report: 45

I refer these two lots without hesitation to the Permian. The fauna of lot 5472 has obvious Paleozoic affinities and shows relationships to the fauna of the Manzano group and that of the Phosphoria formation. The fauna of lot 5476 is in many respects peculiar, for it ccnsists largely of mollusks with a notable rarity though not complete absence of brachiopods. Some of the pelecypods of this fauna (which are represented in greater variety and perfection in other collections) are peculiar, and they apparently represent genera new to the Carboniferous. Nevertheless the Paleozoic age of the fauna seems well assured through the presence of such types as Composita and Euphemus. This is apparently the horizon which has sometimes been called

${ }^{45}$ Gilluly, James, Geology and oil and gas prospects of part of the San Rafael Swell, Utah: U. S. Geol. Survey BuII. 806 , pp. $82-83,1929$. 
the "Bellerophon limestone" and has been regarded as marking the top of the Paleozoic.

5472. Head of Black Box of San Rafael River. Kaibab, just below Moenkopi formation.

Pustula aff. P. montpelierensis.

Pustula nevadensis?

Composita sp.

Edmondia aff. E. gibbosa.

Parallelodon sp.
Schizodus sp.

Aviculipecten sp.

Lima? sp.

Myalina aff. M. perattenuata.

Griffithides sp.

5476. Coquina limestone just below lower shale of Moenkopi formation. Head of Black Box section. Kaibab.

$\begin{array}{ll}\text { Sponge? } & \text { Pleurophorus? sp. } \\ \text { Batostomella? sp. } & \text { Anatina? sp. } \\ \text { Composita mexicana? } & \text { Plagioglypta canna. } \\ \text { Nucula levatiformis } & \text { Bucanopsis modesta } \\ \text { Leda obesa? } & \text { Euphemus subpapillosus } \\ \text { Schizodus? sp. } & \text { Sphaerodoma sp. }\end{array}$

The contained fossils and the stratigraphic relations with the underlying Coconino sandstone and the overlying Moenkopi formation leave little question of the essential continuity of the Kaibab limestone as a lithologic unit between the San Rafael Swell and its type locality in the Grand Canyon, Ariz. At the Grand Canyon the Kaibab is 400 to 600 feet thick. ${ }^{46}$ but the thickness decreases more or less progressively toward the northeast to 250 feet at Lees Ferry, Ariz., ${ }^{47}$ to a recorded maximum of 163 feet in the Circle Cliffs, Utah, ${ }^{48}$ and to an average thickness of less than 100 feet in the San Rafael Swell.49 The San Rafael Swell and the Circle Cliffs lie near the eastern margin of the present extent of the Kaibab limestone. East of those localities, where Permian formations reappear at the surface along the canyon's of the Dirty Devil, Green, and Colorado Rivers, the Kaibab limestone is absent, and it is not present farther east in Utah..$^{50}$

The general eastward thinning of the Kaibab limestone is in large part due to lateral gradation into sandstone, as has been observed in the Grand Canyon ${ }^{51}$ and Kaiparowits regions. ${ }^{52}$

\footnotetext{
${ }^{46}$ Noble, L. F., The Shinumo quadrangle, Grand Canyon district, Ariz.: U. S. Geol, Survey Bull. 549, D. 72, 1914 .

${ }^{47}$ Longwell, C. R., Miser, H. D., Moore, R. C., Bryan, Kirk, and Paige. Sidney, Rock formations in the Colorado Plateau of southeastern Utah and northern Arizona: U. S. Geol. Survey Prof. Paper 132, pl. 1, 1923.

${ }^{48}$ Gregory, H. E., and Moore, R. C., The Kaiparowits region, a geographic and geologic reconnaissance of parts of Utah and Arizona: U. S. Geol. Survey Prof, Paper 164, p. 41, 1931.

40 Gilluly. Tames, ob. cit.. p. 82.

${ }^{50}$ Baker, A. A., and Reeside, J. B., Jr., Correlation of the Permian of southern Utah, northern Arizona, northwestern New Mexico, and southwestern Colorado: Am. Assoc. Petroleum Geologists Bull., vol. 13, pp. 1413-1448, 1929.

${ }^{51}$ McKee, E. D., The environment and history of the Toloweap and Kaibab formations of northern Arizona and southern Utah, Carnegie Inst. of Washington, Pub. 492, pp. 25-26, 1938.

o2 Gregory, H. E., and Moore, R. C., op. cit., p. 45, 1931.
} 
Figure 2 is a diagrammatic illustration of this eastward thinning and shows the lateral gradation of the limestone into the Coconino sandstone of the San Rafael Swell and the progressively greater eastward extent of younger parts of the Kaibab limestone. The uppermost part of the limestone may have extended much farther to the east before it was eroded during the pre-Triassic erosion

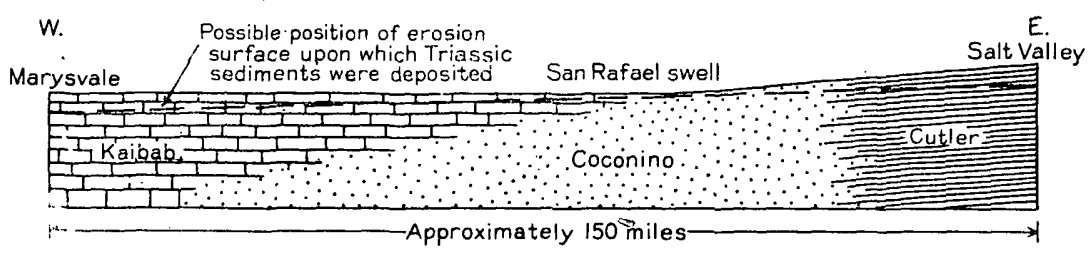

Figure 2.-Generalized diagram showing the stratigraphic relation of the Kaibab limestone to the upper part of the Coconino sandstone and the Cutler formation between Marysvale and Salt Valley, Utah.

interval. However, as indicated on figure 2, the maximum advance of the Kaibab sea may not have reached, or at least may not have encroached far eastward upon the westward sloping aggraded plain that was floored by the red-beds of the Cutler; and the eastern limit of deposition of the formation may have been only a short distance east of the San Rafael Swell. According to either interpretation, the Kaibab limestone of the Swell was deposited during a late stage of the Kaibab sea. The surface produced during the erosion interval which followed withdrawal of the Kaibab sea presumably formed a land surface that sloped to the west from the highland near the Colorado-Utah line and bevelled across the Kaibab sediments. If the land surface were lowered to a position anything like that indicated by the dashed line on figure 2, it is obvious that a younger part of the Kaibab would have been preserved from erosion in the eastern part of its extent than was preserved toward the west. The fossils in the Kaibab limestone of the Swell have some characteristics suggestive of this age relationship of the eastern and western facies of the Kaibab. As noted by Girty (see p. 51) and by $\mathrm{McKee}^{53}$ the fossils from the Kaibab limestone of the San Rafael Swell include some forms that are not typical of the Kaibab limestone at its type locality near the Grand Canyon in Arizona and contains some forms that show relationship to the Phosphoria formation. Recent field work by J. S. Williams and the writer in the southern Wasatch Mountains of north central Utah has shown that the Phosphoria formation overlies rocks which contain a Kaibab fauna.

McKee, E. D., op. cit., pp. 175-176. 
TRIASSIC SYSTEM

LOWER TRIASSIC SERIES

MOENKOPI FORMATION

The Moenkopi formation crops out in the San Rafael Swell and in the southern part of the region along the canyons of the lower Green and Dirty Devil Rivers and their tributaries and along the high cliffs rising above the platform formed by the Cedar Mesa sandstone member of the Cutler adjacent to Cataract Canyon. The rocks of the Moenkopi are, in general, not very resistant to erosion and the formation is typically slope forming. In the San Rafael Swell it is the lower part of the thick series of softer rocks that have been eroded to form the topographic depression between the Reef and the huge central dome of the Swell '(pl. 14). It also forms dip slopes (pl. 13) and forms many of the flat-topped and conical buttes characteristic of the topography of the Swell (pl. 11, B). The resistant cap of these buttes is a relatively thin limestone member in the lower part of the formation. In the southern part of the Green River DesertCataract Canyon region the Moenkopi contains no especially resistant bed, and the formation crops out in a badland slope rising from the platform or bench formed by the more resistant underlying Permian rocks to the cliff formed by the overlying Shinarump conglomerate (pls. $6, B, 12, B$ ) ; where the Shinarump is absent or poorly developed, the Moenkopi and the Chinle form a long slope rising 700 or 800 feet to the base of the cliff formed by the Wingate sandstone. (See pl. 10, B.) Along Green River between Millard Canyon and Elaterite Basin and near the mouth of the Dirty Devil River between The Cove and Hatch Canyon, the Moenkopi forms a thin mantle on the broad bench above the cliff of the White Rim sandstone member of the Cutler; in some places on this bench, because of erosion, the soft Moenkopi rocks form badland topography, but at other places they form a smooth to rolling plain.

The Moenkopi formation consists dominantly of silty sandstone and shale with some conglomerate and limestone and numerous thin beds of gray to red-brown ledge-forming sandstone. On fresh surfaces the rocks are typically dull red brown, but there are numerous thin greenish-gray beds. Weathered surfaces of these rocks are a rather uniform light-chocolate brown. The formation is thin-bedded with beds usually less than one foot thick, and the bedding is very regular. (See pl. 12, A.) Ripple marking is abundant and is one of the most typical features of the formation. Small masses and veinlets of gypsum are common, but bedded gypsum is rare. The Sinbad limestone member of the 
Moenkopi ${ }^{54}$ is 12 to 40 feet thick and consists of gray fossiliferous limestone and gray cross-bedded sandstone; it is 93 to 180 feet above the base of the formation and is a persistant lithologic unit in the San Rafael Swell. (See pl. 13.) McKnight ${ }^{55}$ observed a bed of fossiliferous dark-gray limestone about 320 feet above the base of the formation in the canyon of Green River, which is probably equivalent to the Sinbad limestone, but this limestone was not observed elsewhere in the southern part of the area. A thin bed of conglomerate is present at the base of the formation near the mouth of the Dirty Devil River and at many places in the San Rafael Swell. In the southern part of the area the conglomerate is somewhat irregularly bedded and consists of medium to coarse gray sandstone and some sandy shale with pebbles of fresh blue-gray chert, decomposed chert, and yellow fine-grained sandstone about 2 inches in maximum diameter. In the San Rafael Swell the conglomerate is of similar composition except that limestone pebbles are common.

In the San Rafael Swell and along the canyon of Green River the color of different parts of the Moenkopi change from the typical red brown to a greenish gray that weathers tan or creamy white. Near Black Dragon Canyon the lower part of the formation extending about 100 feet above the Sinbad limestone is tan (pl. 14) and at Straight Wash only the beds below the Sinbad have the abnormal color. At Temple Mountain only the upper one-third of the formation is reddish brown. Near the northern limit of its area of outcrop along Green River the upper half of the formation, with the exception of the uppermost 40 feet, locally has a greenish gray color but changes laterally both upstream and downstream to the normal red-brown color. In the vicinity of Elaterite Basin and farther south the basal beds of the Moenkopi locally are greenish gray to $\tan (\mathrm{pl} .6, B)$, and the boundary between these lighter-colored rocks and the normal red-brown color at some places was observed to cross the bedding planes.

The following sections are more or less typical of the lithology of the Moenkopi in the San Rafael Swell and in the southern part of the area.

Section of the Moenkopi formation on the north side of Temple Mountain Shinarump conglomerate.

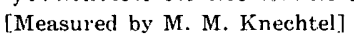

[Measured by M. M. Knechtel]

Unconformity.

Moenkopi formation:

Feet

1. Sandstone and some shale, light greenish-gray and red-brown, thin-bedded

\footnotetext{
${ }^{54}$ Gilluly, James, and Reeside; J. B., Jr., Sedimentary rocks of the San Rafael Swell and some adjacent areas in eastern Utah: U. S. Geol. Survey Prof. Paper 150, p. 65, 1928.

${ }^{s 5}$ McKnight, E. T., Geology of area between Green and Colorado Rivers, Grand and San Juan Counties, Utah: U. S. Geol. Survey Bull. 908, 1940 [1941].
} 
2. Shale, red-brown, interbedded with numerous thin beds of redbrown ledge-forming sandstone and a few thin beds of ochrecolored shale and ripple-marked sandstone.

3. Sandstone, dull-gray, weathering buff to chocolate brown, grading upward to red brown, fine-grained, flaggy.

4. Shale and sandy shale, red-brown.......................................... few beds of hard limy gray ripple-marked sandstone.

6. Sandstone, dull-gray, weathering pink, limy, fine-grained, finely cross-bedded, forms rounded ledge.

7. Sandstone, dull gray, weathering pink, fine-grained, thin-bedded

8. Sandstone like 6

9. Sandstone, gray to red, limy, thin-bedded, interbedded with red sandy shale.

10. Sinbad limestone member-lower 19 feet is gray fossiliferous limestone, and upper part is gray cross-bedded sandstone........

11. Sandstone and shale, thin-bedded, gray to buff, gypsiferous.......

12. Conglomerate, light gray", composed largely of chert nodules derived from the underlying Kaibab limestone embedded in grit, grades upward into sandstone.

Unconformity.

Kaibab limestone.

Section of the Moenkopi formation measured at the south end of South Block on the west side of The Cove

Shinarump conglomerate.

Unconformity.

Moenkopi formation:

Shale, red, with a few beds of platy ripple-marked sandstone.

Sandstone, buff, limy, weathering in blocks, ledge-forming.

Sandstone, silty, red, platy, ripple-marked, interbedded with red shale.

Sandstone, yellow, fine-grained, limy..

Sandstone, platy, ripple-marked, interbedded with red shale.

Sandstone, thin-bedded, gray to buff, forms a conspicuous light band

Sandstone, pink to lavender, medium to fine-grained, cross-bedded, forms slight ledge

Sandstone, reddish-brown, thin-bedded, ripple-marked and dull-red shale. with numerous thin beds of yellowish fine-grained limy sandstone and thick beds of nodular-weathering silty red sandstone.

Sandstone, yellow, fine-grained, limy.

Sandstone, red, thin-bed in

Sandstone, gray to yellow, medium to fine-grained, thin-bedded, slightly petroliferous

Sandstone, gray, medium-grained, beds 1 to 2 feet thick, slightly

Sandstone, red-brown, lenticular beds, medium- to coarse-grained, cross-bedded; lower part contains discontinuous thin beds of conglomerate similar to underlying conglomerate and upper part contains rounded pellets of clay with maximum diameter about 1 inch. 
Conglomerate, coarse-grained, brown to gray petroliferous sandstone matrix with angular to rounded pebbles of decayed chert, chert geodes, and fine-grained sandstone with an average diameter of less than 1 inch and a maximum diameter of 4 inches; bedding is irregular in beds 1 to 3 feet thick, cross-bedded in places.

Unconformity.

White Rim sandstone member of the Cutler formation.

The thickness of the Moenkopi decreases more or less progressively southward across the area. Measured thicknesses are 637 feet at Straight Wash, 684 feet at Temple Mountain, 626 feet at Fort Bottom on Green River, 478 feet at a point west of Big Water Spring in Elaterite Basin, 451 feet at a point east of Elaterite Basin along the trail to Spanish Bottom, 368 feet at Teapot Rock, 359 feet at the head of Clearwater Canyon, and 326 feet on the west side of The Cove at the south end of South Block.

Pre-Moenkopi erosion removed the Kaibab limestone in large areas, and the thickness of the Kaibab removed shows that the surface had local relief of 100 feet or more. A basal conglomerate of the Moenkopi, the pebbles of which consist largely of residual chert weathered from the Kaibab, was deposited in depressions on that surface. No angular discordance was observed at this horizon; the Shinarump conglomerate of Upper Triassic age unconformably overlies the Moenkopi.

Fossils collected from the Sinbad limestone member establish the Lower Triassic age of the Moenkopi formation. ${ }^{56}$ Correlation between the Green River Desert-Cataract Canyon region and the type locality of the formation in northern Arizona ${ }^{57}$ is based upon regional tracing across the intervening country by several geologists, upon its typical lithology, and upon its stratigraphic position between the Kaibab limestone and the Shinarump conglomerate.

The Sinbad limestone is clearly of marine origin, and therefore a Lower Triassic sea extended into and perhaps covered the entire Green River Desert-Cataract Canyon region during one stage of Moenkopi time. No other part of the formation is clearly of marine origin, although some clastic material must have been deposited in other parts of the sea at the time the limestone was deposited in the northern part of the area; the gypsum that is common in the formation is suggestive of marine conditions. The

\footnotetext{
${ }^{66}$ Gilluly, James, and Reeside, J. B., Jr., Sedimentary rocks of the San Rafael Swell and some adjacent areas in eastern Utah: U. S. Geol. Survey Prof. Paper 150, p. 66, 1928. Baker, A. A., Dobbin, C. E., McKnight, E. T., and Reeside, J. B., Jr., Notes on the stratigraphy of the Moab region, Utah: Am. Assoc. Petroleum Geologists Bull., vol. 11, p: 797, 1927.

${ }^{52}$ Gregory, H. E., Geology of the Navajo country, a reconnaissance of parts of Arizona, New Mexico, and Utah: U. S. Geol. Survey Prof. Paper 93, pp. 23-24, 1917.
} 
thin, regularly bedded, fine-grained sediments might be considered to indicate deposition in deep quiet water but the occurrence of "fossil" mud cracks at several horizons shows that shallow-water conditions prevailed and that the sediments were repeatedly exposed to the air. It is possible that a large part of the formation was deposited under continental conditions, perhaps as flood-plain deposits near the sea.

UPPER TRIASSIC SERIES

SHINARUMP CONGLOMERATE

The Shinarump conglomerate, which overlies the Moenkopi formation in most of the region, is a cliff- and bench-forming formation. (See pls. $6, B, 10, A$.) It crops out extensively in the southern part of the region along the cliffs parallel to the Colorado River and along the canyon walls of the streams tributary to the Green and Dirty Devil Rivers. In nearly all parts of its outcrop in the southern part of the region it forms nearly vertical cliffs to. which the name "Black Ledge" has been applied by local inhabitants. At many places these cliffs form a sheer wall between the slopes formed by the overlying Chinle formation and the underlying Moenkopi formation, but at other places the overlying softer rocks have been removed by erosion, and the cliffs rim flat-topped mesas or benches floored by the Shinarump. These mesas and benches are prominent topographic features in the vicinity of Elaterite Basin, where they support a dense growth of pinon and juniper; the dark green of the tree-covered benches is in striking contrast with the bare-rock slopes of the surrounding areas when seen from the top of the higher nearby cliffs. The Shinarump conglomerate also crops out along the inside of The Reef on the flank of the San Rafael Swell, where it forms a prominent ledge and locally is the resistant rim rock of pronounced benches. (See pl. 14.)

The Shinarump conglomerate consists principally of sandstone that is irregularly conglomeratic. The sandstone is medium- to coarse-grained, more or less cross-bedded and irregularly bedded. At places the entire formation is conglomeratic, but at other localities the sandstone is conglomeratic only in lenses or streaks. The pebbles consist of quartz, quartzite, chert, limestone, sandstone, and clay pellets ranging in diameter from a fraction of an inch to a maximum of 3 inches or more; the limestone pebbles were observed only at outcrops in the San Rafael Swell. The general color of the Shinarump is gray on fresh surfaces, but many weathered surfaces have acquired a brownish black coating of desert varnish. Interbedded with the conglomeratic gray sandstone are many lenticular beds of greenish-gray sandy shale 


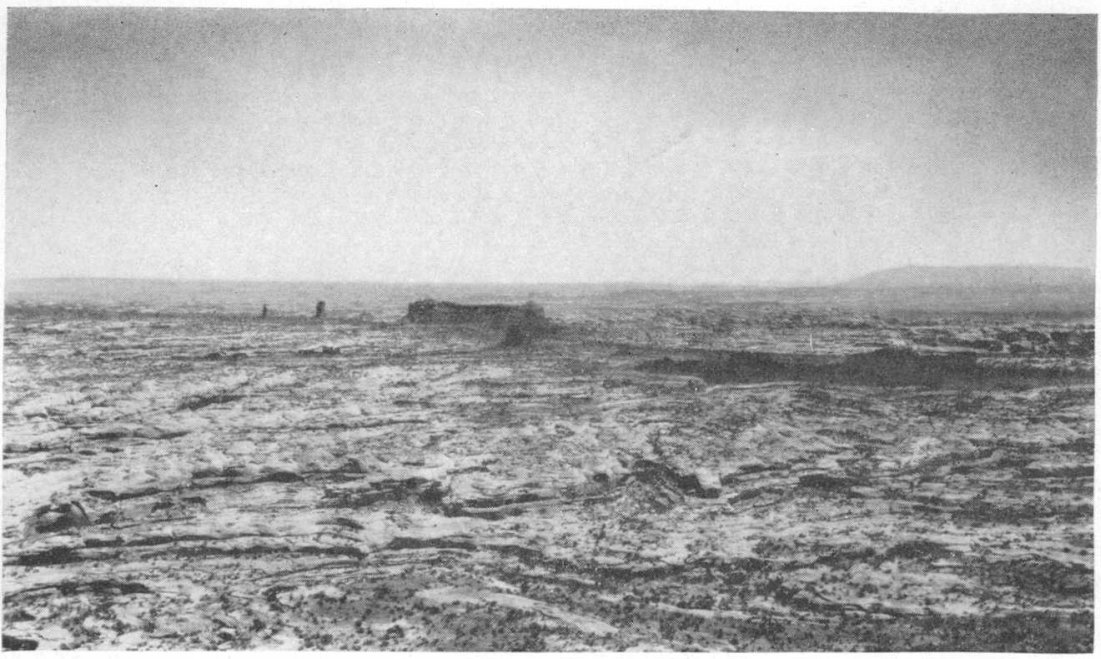

A. DISSECTED CEDAR MESA SANDSTONE BENCH SOUTHWEST OF MOUTH OF GREEN RIVER.

The red rocks of the Organ Rock tongue of the Cutler formation form Lizard Rock, the large butte in middle distance and Standing Rock and Candlestick Spire, the slender spires to the left of Lizard Rock.

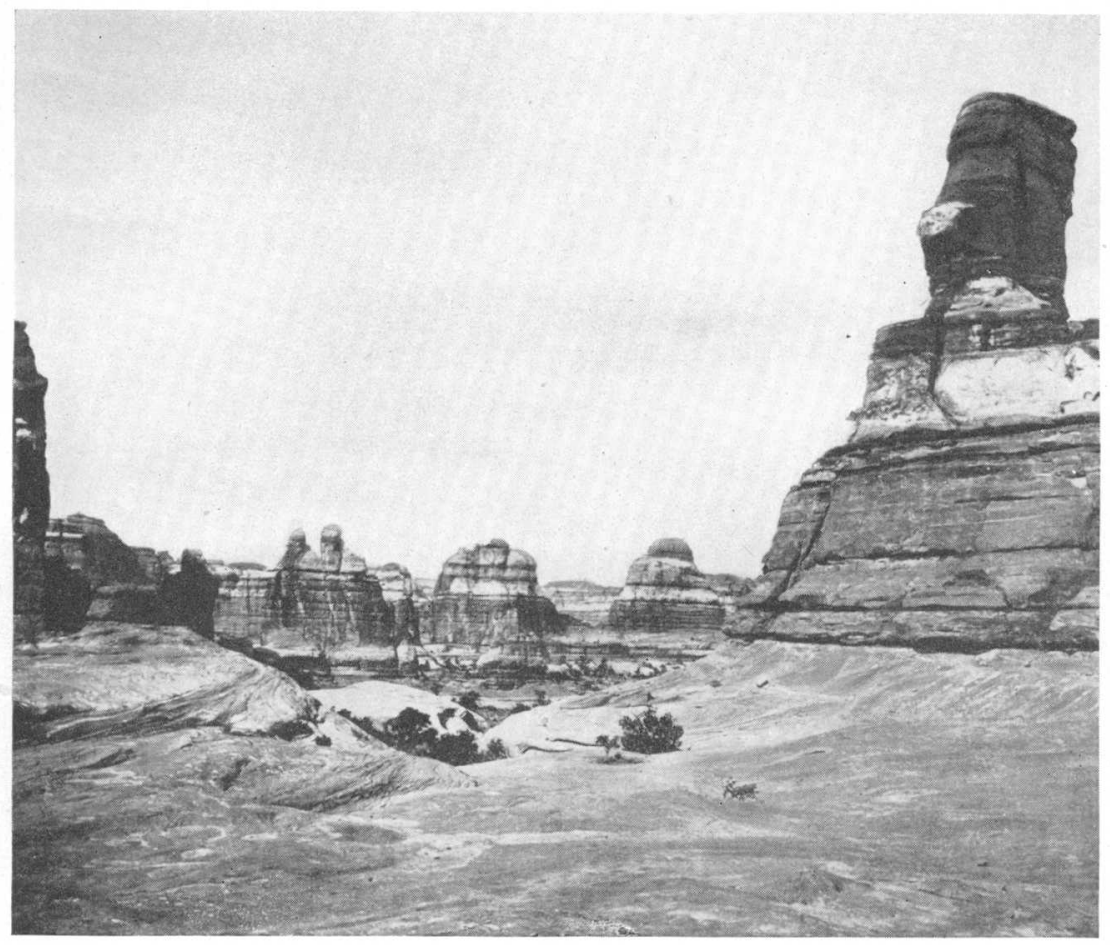

B. RED AND WHITE BANDED CEDAR MESA SANDSTONE MEMBER OF CUTLER FORMA. TION NEAR EDGE OF RIVER CANYON, WEST OF MOUTH OF GREEN RIVER. 


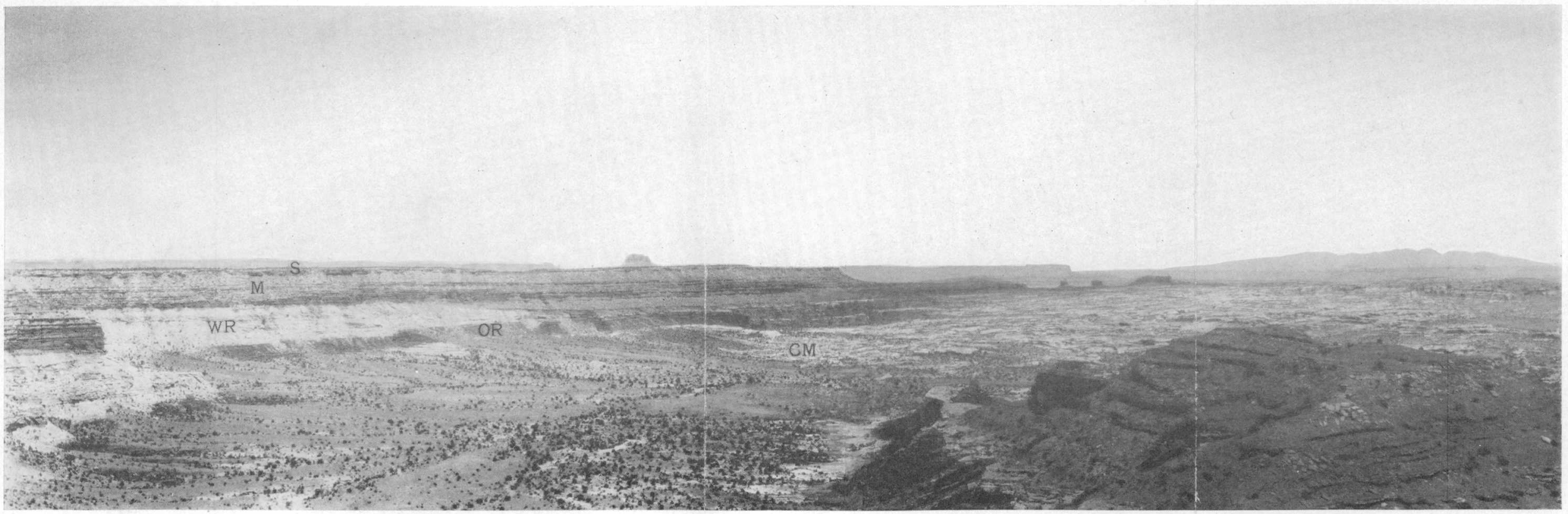

A. WEDGING OUT OF WHITE RIM SANDSTONE MEMBER OF GUTLER FORMATION AT HEAD OF RANGE CANYON.

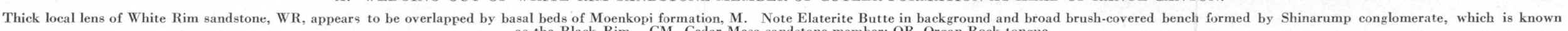

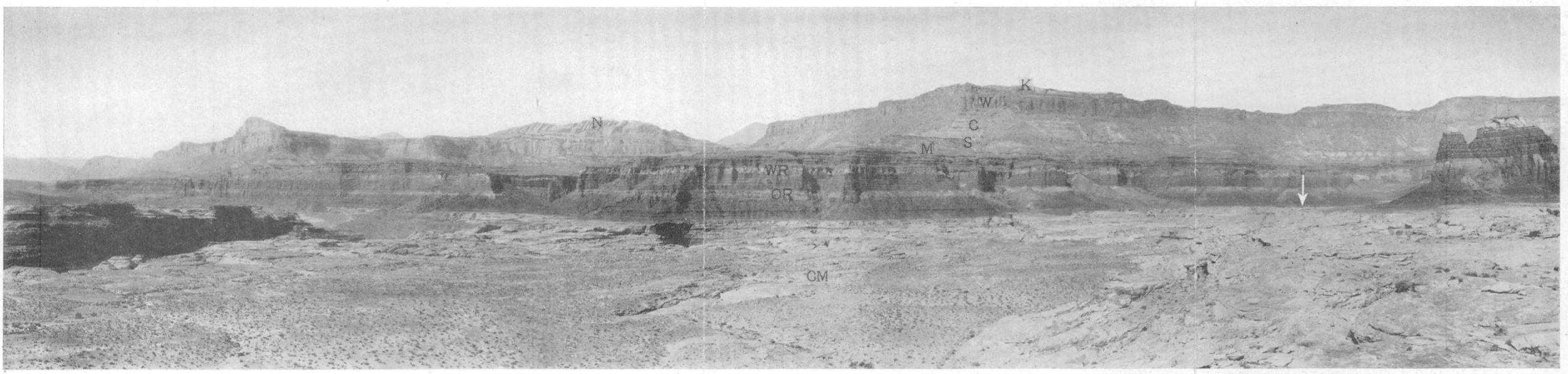

B. MOUTH OF DIRTY DEVIL RIVER.

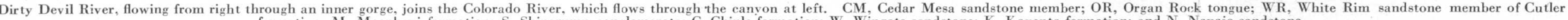
( 
and gray to buff shaly sandstone. Fossil wood is abundant. In the vicinity of Temple Mountain the Shinarump is saturated with an asphaltic substance and the color of the formation is black; the asphaltic sandstone is impregnated with vanadium minerals, which have been extensively prospected. As far as known, the Shinarump does not contain vanadium minerals elsewhere in the area. The thickness of the Shinarump ranges from less than a foot to a maximum observed thickness of 135 feet; it was not distinguished as a separate formation in parts of the area near the mouth of the Dirty Devil River and in the lower part of Labyrinth Canyon. The thickness of the Shinarump is 105 feet on the west side of the Dirty Devil River near its mouth, 135 feet on the west side of The Cove at the south end of South Block, 60 feet at Sunset Pass, 125 feet at South Trail, 122 feet at trail near the head of Big Fork of Happy Canyon, 107 feet at Middle Trail, 82 feet west of Big Water spring, 93 feet at Elaterite Butte, 53 feet at the north end of North Point, 50 feet at Fort Bottom, 94 feet at Temple Mountain, and 125 feet at Straight Wash.

The Shinarump conglomerate rests upon an eroded surface of the Moenkopi formation. At its upper contact the Shinarump grades into the overlying Chinle formation. This gradation takes place at many localities through a series of thin-bedded sandstone and sandy shale beds, and it is difficult to select a precise boundary between the formations. Of greater significance, however, is the lateral gradation that is present at other localities. About 1 mile east of the foot of Middle Trail a tongue of the massive conglomerate splits from the main ledge and extends westward above a bed of typically variegated shale in the Chinle; in a distance of 700 feet the tongue of conglomerate wedges out at a horizon 20 feet above the base of the shale. On the west side of The Cove near the south end of the South Block the upper 75 feet of typically Shinarump conglomerate grades southward in a distance of 1,000 feet into rocks of Chinle lithology; it seems highly probable that the absence of the Shinarump in much of the extreme southern part of the area is the result of lateral gradation into rocks of - Chinle type. The most satisfactory concept of the Shinarump conglomerate is that of a basal conglomerate of the Chinle formation.

Fossil wood is abundant in the Shinarump but no fossils diagnostic of the age of the formation were found in the area. Fossil wood from the Shinarump is reported to have Upper Triassic affinities and fragments of cycad foliage found in the formation in the Kaiparowits region ${ }^{58}$ may be of Upper Triassic

\footnotetext{
${ }^{88}$ Gregory, H. E., and Moore, R. C., The Kaiparowits region, a geographic and geologic reconnaissance of parts of Utah and Arizona: U. S. Geol. Survey Prof. Paper 164, p. 53, 1931.
} 
age. ${ }^{59}$ The assignment of the Shinarump to the Upper Triassic is largely based upon its relations to the enclosing formations. It is separated from the underlying Lower Triassic Moenkopi formation by an erosional unconformity and grades into the overlying Upper Triassic Chinle formation. Because of the lateral gradation of the Shinarump into rocks typical of and inseparable from the Chinle, it is obvious that the Shinarump is the age equivalent of beds that locally form the lower part of the Chinle.

The Shinarump conglomerate is a persistent unit that has been identified on the basis of its lithology and stratigraphic position practically everywhere that its horizon appears at the surface in an area of 100,000 square miles or more. Its thickness rarely exceeds 200 feet, and its average thickness probably is less than 100 feet. This widespread relatively thin formation with its coarse sediments, irregular bedding, and cross bedding appears to have been deposited by shifting streams upon a surface of slight local relief; the source of the sediments is not known.

\section{CHINLE FORMATION}

The Chinle formation crops out in the high cliffs and canyon walls in the southern part of the area from the mouth of Keg Spring Canyon on Green River to the Dirty Devil River above the mouth of Twin Corral Box Canyon and also along the inside of the Reef on the flank of the San Rafael Swell. It crops out in slopes that rise steeply from the cliffs or benches formed by the Shinarump conglomerate to the foot of the cliff formed by the overlying Wingate sandstone; the slopes are typically strewn with a mantle of debris, which falls from the cliffs above them. (See pls. 6, $B, 12, B$.) Where the Shinarump conglomerate is absent the Chinle and the underlying Moenkopi weather into a long, practically unbroken slope extending across a stratigraphic thickness of 800 feet or more. Much of the scenic grandeur of the canyon region in the southern part of the area is due to the deep canyons produced by the rapid erosion and removal of the great thickness of easily eroded rocks that make up those formations. The strike valley between the Reef and the huge central dome of the San Rafael Swell also is the result of the erosion of the great thickness of nonresistant rocks in the two formations. (See pl. 14.)

The rocks of the Chinle formation consist principally of interbedded shale, sandstone, and subordinate conglomerate. The lower one-half or two-thirds of the formation in the southern part of the area is dominantly shale and sandy. shale variegated in

${ }^{59}$ Berry, E. W., Cycads in the Shinarump conglomerate of southern Utah: Washington Acad. Sci. Jour., vol. 17, pp. 303-307, 1927. 
pastel shades of red, maroon, lavender, brown, pink, gray, blue, and green. The shale commonly weathers deeply, forming a layer of loose flakes covered by a hard crust that will support a person's weight; the hardness of the crust and the roller-bearing effect of small frägments of debris cause treacherous footing and the steep slopes are difficult to climb. Interbedded with the shale are occasional thin beds of conglomerate, in some of which the pebbles consist principally of limestone, but some beds contain pebbles of chert, quartz, quartzite, sandstone, shale, and clay pellets. A few thin beds of gray to red sandstone and rarely a thin bed of unfossiliferous greenish-gray sandy limestone are interbedded with the shale. In the San Rafael Swell the lower part of the formation contains some variegated shale, but much red-brown sandstone and shale are interbedded with it. The upper part of the formation consists of irregularly bedded buff to red-brown, fine- to medium-grained sandstone, with occasional streaks of grit interbedded with reddish-brown shale. At some localities the uppermost 25 to 40 feet of the formation consists of dark-purplish, irregularly bedded, cross-bedded arkosic sandstone, but at other localities the uppermost beds are buff to lightorange-brown sandstone, which resembles the sandstone of the overlying Wingate. Fossil wood is abundant in the Chinle formation, and some fragments are slightly carbonized.

The following section of the Chinle is representative of the lithology of the formation in the southern part of the area.

Section of the Chinle formation measured on the west side of the Cove at the south end of South Block

Wingate sandstone.

Chinle formation:

Sandstone, lavender, arkosic, fine- to coarse-grained, thick-bedded...

Shale; sandy, light-brown.

Sandstone, light-brown, fine-grained, ledge-forming.

Shale, sandy light-brown.

Sandstone, light-brown, fine-grained.

Shale, light-brown to pale-pink with a few beds of harder limy shale

Shale, pale-lavender, limy

Limestone, sandy, greenish-gray with some brownish-lavender shale in upper part

Shale, brownish-lavender.

Conglomerate, greenish-gray, coarse-grained sandstone with rounded pebbles of sandy limestone, 2 inches maximum diameter

Shale, pinkish-red

Shale, limy, grayish-lavender.

Shale, limy, pale-lavender, nodular-weathering, ledge-forming, contains small gastropods.

Shale, pinkish-red to greenish-white with a few thin beds of nodular sandy limestone. 
Limestone, sandy, pink to greenish-gray, nodular.

Shale, purplish-red with large areas bleached to greenish-white.

Conglomerate, greenish-gray, coarse-grained sandstone with rounded pebbles of limestone, one inch maximum diameter.

Shale, variegated in shades of light-brown, pink and pale-lavender

Shale, pale-lavender.

Sandstone, lavender, coarse-grained, slightly cross-bedded, ledgeforming

Shale, variegated in shades of red, lavender, gray, brown, with abundant limy nodules in lower part; grades northward into typical Shinarump.

Shinarump conglomerate.

The thickness of the Chinle is 265 feet at Temple Mountain and 280 feet at Straight Wash in the San Rafael Swell. In the southern part of the area the formation is thicker, as shown by measurements of 419 feet at Fort Bottom on Green River, 443 feet on the west side of Millard Canyon near its mouth, 386 feet on North Trail, 432 feet at Elaterite Butte, 438 feet in the head of a small draw about 1 mile east of the Middle Trail, 425 feet along the South Trail and in the Big Fork of Happy Canyon, and 455 feet in the Cove. The thickness of 455 feet in the Cove includes 36 feet of rocks that are the lateral equivalent of typical Shinarump rocks and that are included in the thickness of 155 feet of Shinarump measured near the same locality.

The contact of the Chinle with the underlying Shinarump conglomerate is as previously explained, gradational. The contact with the overlying Wingate is sharp and marks an abrupt change in lithology at most places in the area, but at other places there is a gradation from typical Chinle lithology through a series of irregularly bedded sandstones into the massive Wingate sandstone, and the contact is placed more or less arbitrarily at the top of the bedded sandstone. Where the contact is sharp the top of the Chinle shows slight relief, and streaks of grit and chunks of shale and sandstone are occasionally present in the base of the Wingate. Near the point where the outcrop of the Wingate sandstone crosses Black Dragon Canyon the contact between the Wingate and Chinle is in general a sharp lithologic boundary, but the base of the sandstone shows casts of mud cracks that are about 5 miles wide and are arranged in polygons with a width of about 5 feet. Several authors have expressed the opinion that an erosional unconformity is present at the top of the Chinle ${ }^{80}$ in this part of Utah,

co Emery, w. B., The Green River Desert section. Utah: Am. Jour. Sci., 4th ser., vol. 46, p. 563, 1918. Longwell, C. R., and others, Rock formations in the Colorado plateau of southeastern Utah and northern Arizona: U. S. Geol. Survey Prof. Paper 132, p. 11, 1925. Gilluly, James, and Reeside, J. B., Jr., Sedimentary rocks of the San Rafael Swell and some adjacent areas in eastern Utah: U. S. Geol. Survey Prof. Paper 150, p. 68, 1928. 
but the presence of mud cracks clearly shows that the overlying sandstone was deposited upon unconsolidated clay soon after the cracks were formed and the gradational lithology present at other localities is suggestive of essentially uninterrupted deposition. The writer believes that the contact is conformable.

The only fossils other than silicified wood collected from the Chinle formation in the Green River Desert-Cataract Canyon region were a few small gastropods from a limy shale 272 feet below the top of the formation where the section was measured on the west side of the Cove. These fossils have been described by Yen and Reeside ${ }^{61}$ as Triasamnicola pilsbryi and T. latispira. They constitute the only record of nonmarine Triassic gastropods. Fossil remains of vertebrate animals that have been found in the Chinle formation at many places in the Colorado Plateau have been identified as Upper Triassic in age. ${ }^{62}$ The correlation of the Chinle with the type locality in northern Arizona $^{63}$ is unquestioned because the typical Chinle lithology in the stratigraphic position between the Shinarump conglomerate and Wingate sandstone has been traced across the intervening region. ${ }^{64}$

Fossil remains, both of invertebrate animals collected by the writer in the Cove and near Moab, Utah, ${ }^{65}$ and of the vertebrate animals found in the Chinle, are types that lived in fresh water under continental conditions. ${ }^{66}$ The irregular bedding, poor sorting of material, and cross bedding of some of the sandstones probably indicate fluviatile conditions of deposition for at least part of the formation. The variegated clays may be in part lacustrine, but possibly they represent fluviatile sediments carried far out into the basin of deposition.

\section{JURASSIC(?) SYSTEM}

\section{GLEN CANYON GROUP}

The Glen Canyon group includes three formations, the Wingate sandstone at the base, the overlying Kayenta formation, and the Navajo sandstone at the top. The type region of the group is Glen Canyon of the Colorado River only a few miles southwest of

\footnotetext{
61 Yen, Teng-Chien, and Reeside, J. B., Jr., Triassic fresh-water gastropods from southern Utah; Am. Jour. Sci., vol. 244, pp. 49-51, 1946.

Camp, C. L., A study of the phytosaurs: California Univ. Mem., vol. 10, p. 4, 1930.

${ }^{63}$ Gregory, H. E., Geology of the Navajo country, a reconnaissance of parts of Arizona, New Mexico, and Utah: U. S. Geol. Survey Prof. Paper 93, pp. 42-43, 1917.

Gregory, H. E., The San Juan country, a geographic and geologic reconnaissance of southeastern Utah: U. S. Geol. Survey Prof. Paper 188, p. 49, 1938. Longwell, C. R., and others, Rock formations in the Colorado Plateau of southeastern Utah and northern Arizona: U. S. Geol. Survey Prof. Paper 132, p. 11, pls. 1 and 2, 1925.

CS Baker, A. A., Geology and oil possibilities of the Moab district, Grand and San Juan Counties, Utah: U. S. Geol. Survey Bull. 841, pp. 40-41, 1933.

${ }^{66}$ Camp, C. L., op. cit., pp. 6-9.
} 
the mouth of the Dirty Devil River ${ }^{67}$ and there is no appreciable change in the lithology of the rocks included in the group between the type region and the Green River Desert-Cataract Canyon region. No fossils diagnostic of the age of the Wingate, Kayenta, or Navajo sandstone have been found, and the entire group is tentatively assigned to the Jurassic principally on the basis of its stratigraphic position between the Upper Triassic Chinle formation and the Upper Jurassic Carmel formation. The age, correlation, history of nomenclature, and origin of the formations comprising the Glen Canyon group have been discussed in another report $^{68}$ to which the reader is referred for a more comprehensive discussion.

\section{WINGATE SANDSTONE}

The Wingate sandstone, the lowest of the three members of the Glen Canyon group, crops out along canyons and cliffs in the southern part of the area. Its outcrop forms a practically vertical wall approximately 300 feet high, which is one of the most striking features of the topography of that part of the area. (See pls. 10, $B, 12, B$.) Except for a thin capping of rocks of the overlying Kayenta formation, the Wingate is the rim rock of the canyons and cliffs and marks the boundary of the upland surface. The wall of Wingate sandstone can be crossed only at a few places where trails have been built to permit stock to move from one part of the area to another; it forms such a definite geographic boundary that it is known to local people as the "Ledge," and all the area below the rim rock is designated as "under the Ledge". The Wingate also crops out along the border of the San Rafael Swell, where it forms part of the serrate comb of the Reef. (See pl. 14.) It forms a cliff bordering the east side of the strike valley between the Reef and the central dome of the Swell; at most places the cliff is vertical and represents the full thickness of the Wingate, but as the dip increases the top of the Wingate is eroded back from the rim, and in the area of steepest dips a few miles north of straight Wash the formation is standing nearly vertical and crops out in a sheer wall with a serrate crest.

The Wingate sandstone is a nearly homogeneous fine- to medium-grained quartz sandstone poorly cemented with lime and silica. The grains are subangular to rounded and are more or less coated with iron oxide. Angular pebbles of shale and sandstone and discontinuous stringers of grit are present locally at the base. On fresh surfaces the rock is pale reddish tan to light

\footnotetext{
67 Gregory, H. E., and Moore, R. C., The Kaiparowitz region, a geographic and geologic reconnaissance of parts of Utah and Arizona: U. S. Geol. Survey Prof. Paper 164, p. 61, 1931.

${ }^{68}$ Baker, A. A., Dane, C. H., and Reeside, J. B., Jr. Correlation of the Jurassic formations of parts of Utah, Arizona, New Mexico, and Colorado: U. S. Geol. Survey Prof. Paper 183, 1936.
} 
orange brown, but it weathers to a brownish red and is commonly coated with bluish-black desert varnish. The sandstone crops out in vertically jointed cliffs in which bedding is vague and discontinuous, and the Wingate appears to be a single massive bed. Where the sandstone is deeply etched by weathering, as in the upturned edges along the Reef, it shows numerous bedding planes and intricate large-scale cross bedding.

The thickness of the Wingate is fairly constant in the Green River Desert-Cataract Canyon region. It is 323 feet thick at Black Dragon Canyon, 314 feet where the main fork of Iron Wash crosses the Reef, 295 feet on Green River near the mouth of Horseshoe Canyon, 284 feet at a point northwest of Big Water Spring, 270 feet on North Trail, 285 feet on the point between the Main and Big Forks of Happy Canyon, 304 feet on South Trail, 273 feet at Lands end, 286 feet near Red Point, 275 feet on the trail leading onto South Block, and 279 feet on the west side of the Dirty Devil River near its mouth. Some of the variation in measured thicknesses may be due to difficulties in selecting precise boundaries for either the top or bottom of the formation at many localities.

The uper contact of the Wingate throughout most of its outcrop is inaccessible because of its position in the upper part of a vertical cliff, and it was examined in detail at few localities. At some places the contact is sharp and is marked by a thin bleached zone and a slightly irregular surface at the top of the sandstone that may represent an unconformity. At other places, however, there appears to be a gradation between the massive Wingate sandstone and the overlying Kayenta formation. The gradation is through irregularly bedded sandstone of similar lithology, and the boundary was selected arbitrarily at the upper limit of the massive sandstone; it is probable that the contact was not placed at the same horizon in all parts of the area.

No fossils were found in the Wingate sandstone, but its correlation throughout southeastern Utah is unquestioned because of its distinctive lithology, and its stratigraphic position between the Chinle and Kayenta formations. It includes only the lower part of the Wingate sandstone of Emery ${ }^{69}$ who included all of the Glen Canyon group in that formation.

It seems probable that the homogeneous cross-bedded sandstone of the Wingate represents a wind-laid deposit.

\section{KAYENTA FORMATION}

The Kayenta formation is the middle unit of the Glen Canyon

\footnotetext{
${ }^{69}$ Emery, W. B., The Green River Desert section, Utah: Am. Jour. Sci., 4th ser., vol, 46, pp. $564-568,1918$.
} 
group and consists principally of irregularly bedded sandstone, which is in striking contrast with the overlying and underlying massive sandstones. The lower part of the formation crops out at the top of the cliff formed by the Wingate sandstone and is the resistant capping that protects the less resistant sandstone of the Wingate from erosion. (See pls. 10, $B, 14$.) The upper part of the Kayenta seems to be less resistant to erosion than the lower part and at most places has been eroded back from the top of the Wingate cliff to form benches, which extend to the foot of the cliff formed by the overlying Navajo sandstone. (See pl. 15.) The benches have low relief but are dissected by gulches and crossed by numerous ledges and low cliffs. They usually support a somewhat denser growth of trees than the parts of the upland surface floored by other formations. The Kayenta formation rises above the level of Green River about $11 / 2$ miles below the mouth of Three Canyons and above the level of the Dirty Devil River near the mouth of Robbers Roost Canyon; it forms the floor of large parts of the intervening upland surface, particularly in the areas adjacent to Happy and Horsethief Canyons and on North Point. The upper part of the Kayenta crops out in the bed of Horseshoe Canyon through the greater part of its course. The Kayenta also crops out along the Reef, bordering the San Rafael Swell. It floors long slopes south of Straight Wash and in the northern part of The Reef in the vicinity of the San Rafael River, but in the intervening area where the dip of the beds is nearly vertical its belt of outcrop is narrow and is confined to the center of The Reef.

The Kayenta formation is composed of sandstone with some interbedded shale and conglomerate. The sandstone is fine- to coarse-grained, reddish brown, lavender, buff and gray in beds from a fraction of an inch to tens of feet in thickness. Individual beds are lenticular and are commonly cross-bedded. The lower part of the formation which crops out in the cliffs above the Wingate sandstone is usually coated with bluish-black desert varnish, but on fresh surfaces its color is reddish brown similar to the color of the Wingate. Upward, the color of the sandstone changes more or less through lavender to gray and buff near the top, where it resembles the color of the overiying Navajo sandstone, although at many places the uppermost beds of the Kayenta have a faint lavender tint that aids in distinguishing them from the Navajo. Some of the sandstone beds contain grit and clay pellets. Interbedded with the sandstone are occasional beds of conglomerate containing angular fragments, 2 inches or more in diameter, of sandstone, shale, or limestone and thin lenses of red to greenish-gray shale are common. The Kayenta is 294 feet thick 


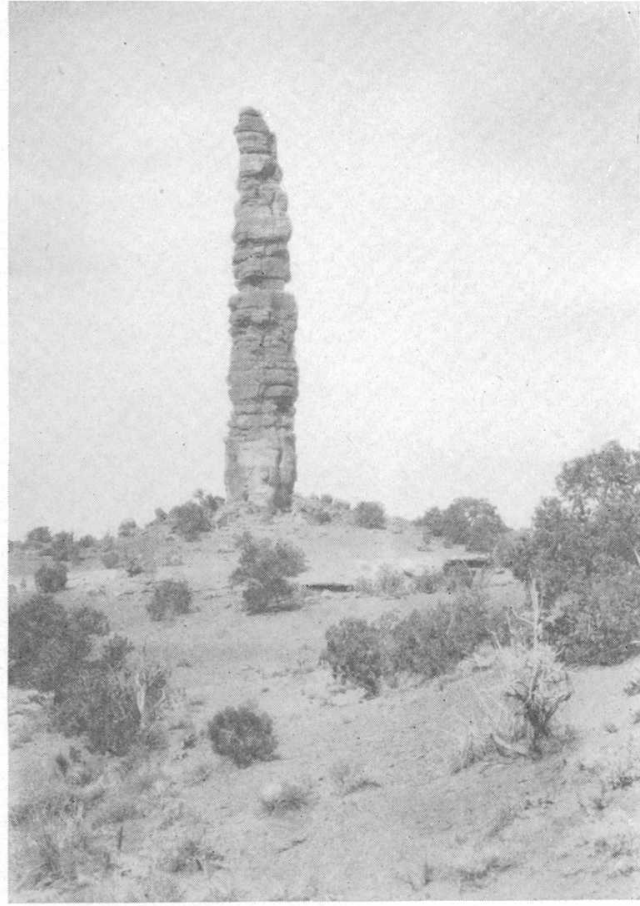

A. STANDING ROCK ON TRAIL TO SPANISH BOTTOM.

The slender spire, about 180 feet high is an erosion remnant of the Organ Rock tongue of Cutler formation.

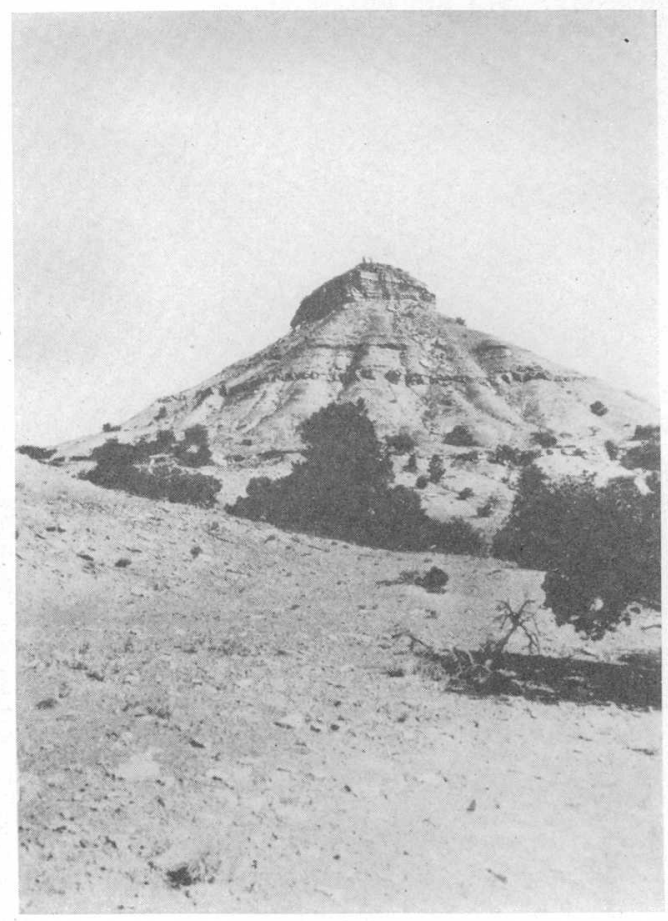

B. TYPICAL OUTCROP OF LOWER PART OF MOENKOP FORMATION ON CREST OF SAN RAFAEL SWELL.

The butte, which is near well drilled by Carter Oil Co., is capped
by Sinbad limestone member of Moenkopi formation. Photograph by A. J. Eardley.

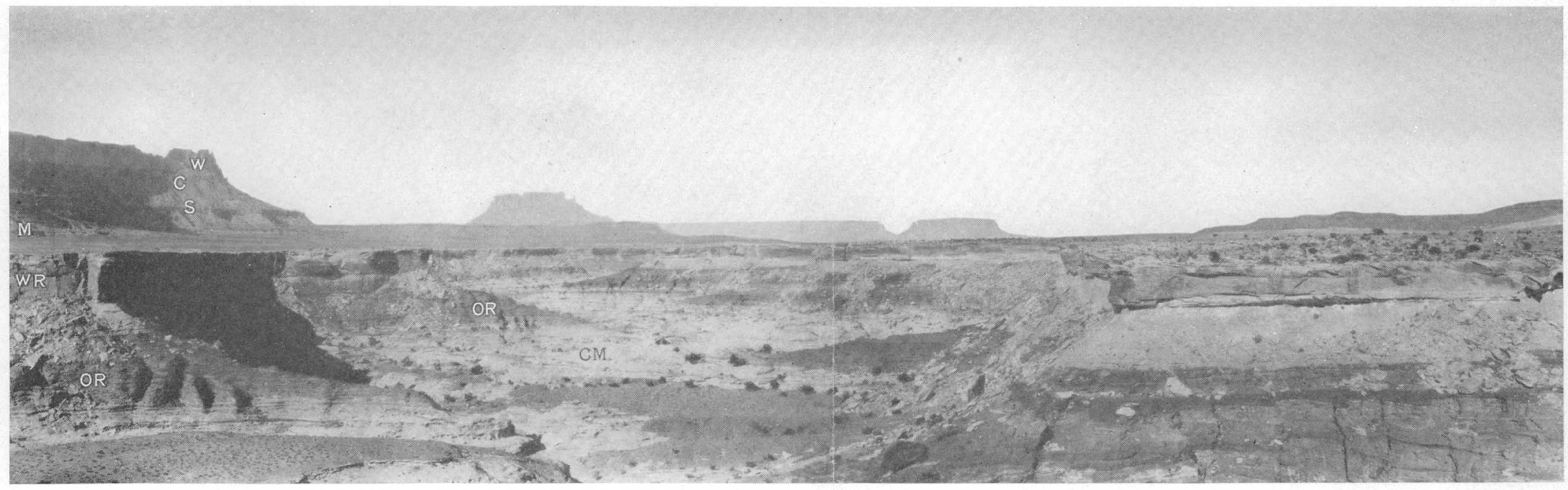

C. CUTLER FORMATION IN HORSE CANYON NORTHWEST OF ELATERITE BUTTE.

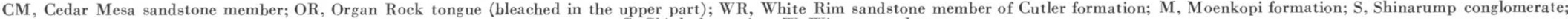
$\mathrm{C}$, Chinle formation; $\mathbb{W}, \mathbb{W}$ ingate sandstone. 


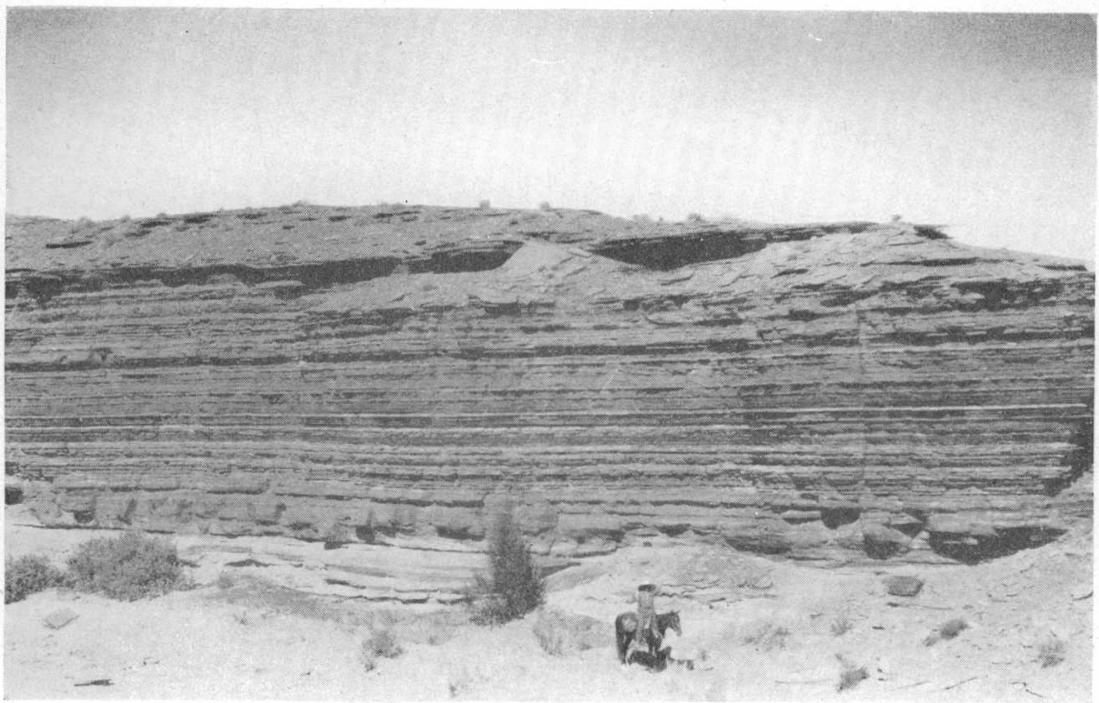

A. OUTCROP OF MOENKOPI FORMATION IN ELATERITE BASIN.

Shows the characteristic thin and regular bedding.

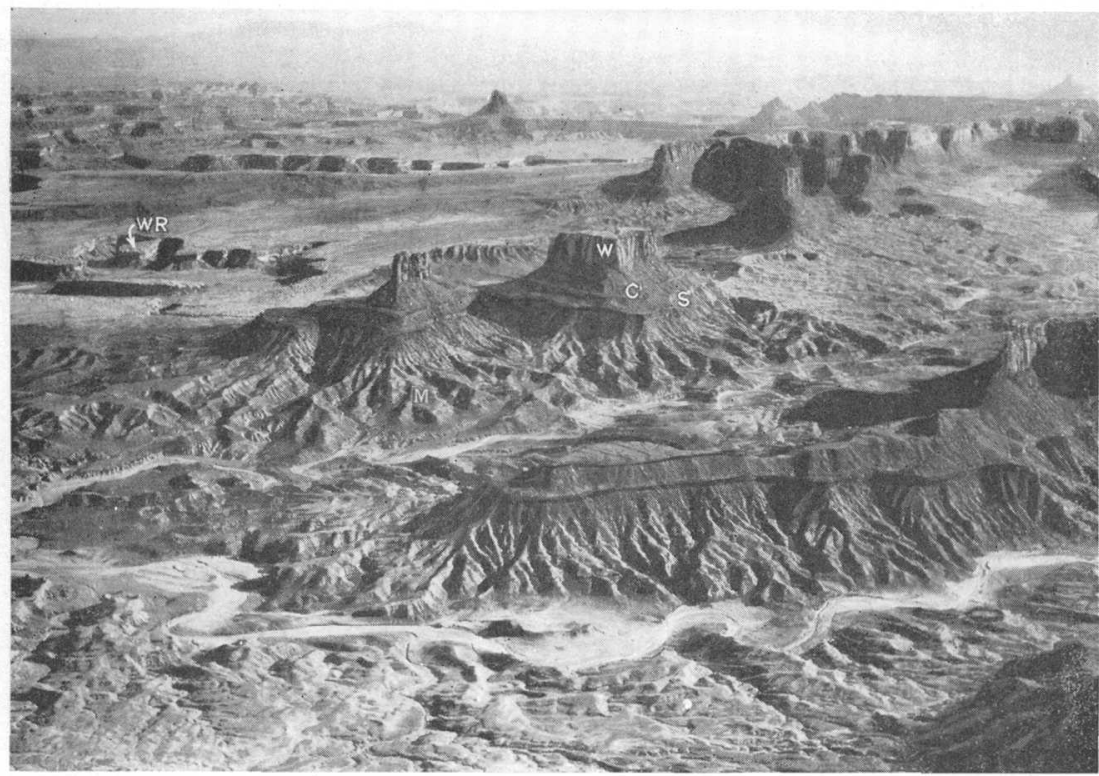

\section{$B$. AERIAL VIEW SOUTHEAST FROM MILLARD CANYON.}

Shows broad bench above White Rim sandstone, WR; badland slopes of Moenkopi formation, M; Shinarump conglomerate, S; Chinle formation, C; and numerous buttes capped by erosion remnants of the Wingate sandstone, $\mathbb{W}$. In background, the Blue Mountains show at the left and Elaterite Butte at right. Photograph by National Park Service. 


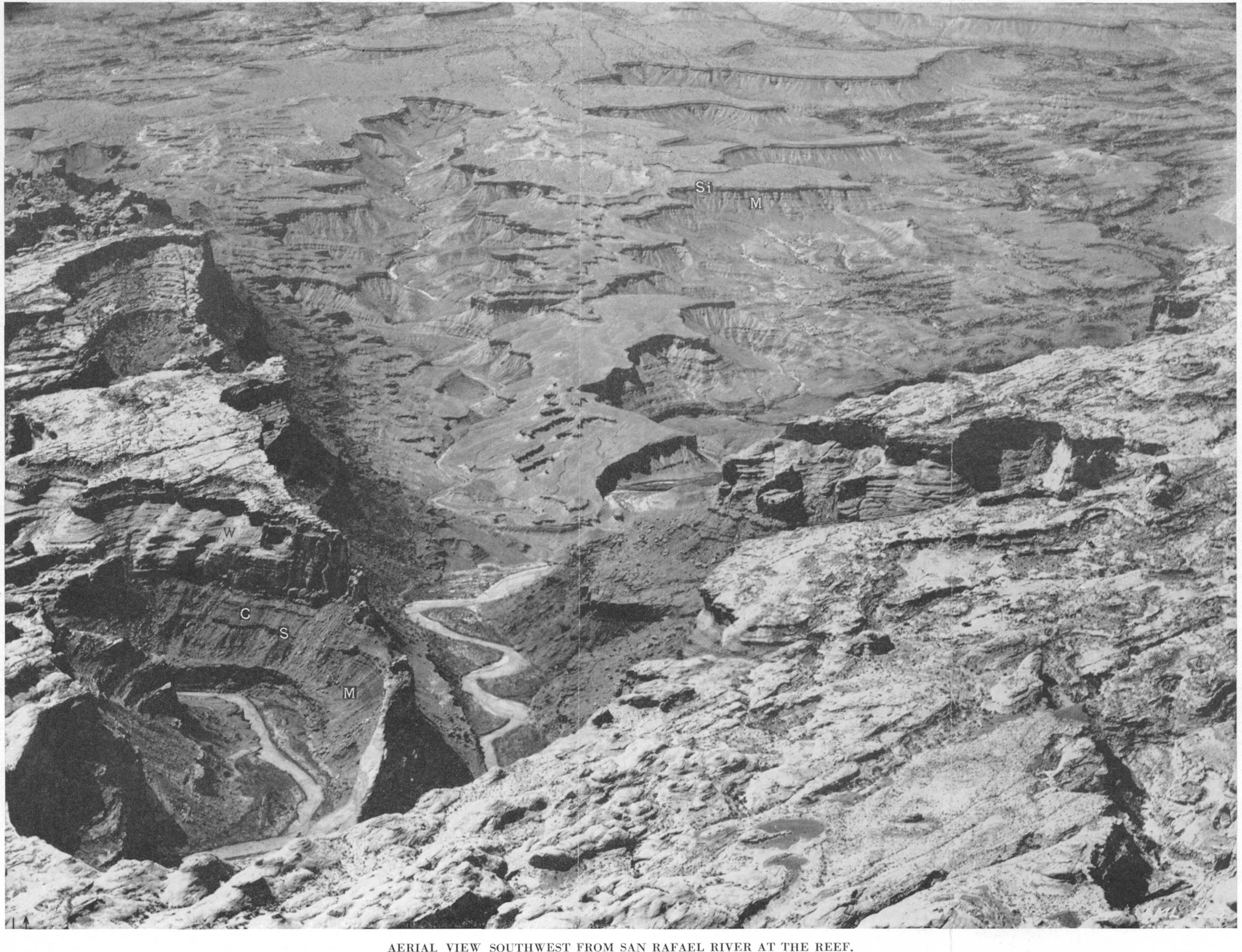

AERIAL VIEW SOUTHWEST FROM SAN RAFAEL RIVER AT THE REEF.

Shows San Rafael River in foreground; Moenkopi formation, M; dip slopes floored by the Sinbad limestone member, Si, of Moenkopi formation; Shinar
Published by permission of Barnum Brown, American Museum of Natural History. 


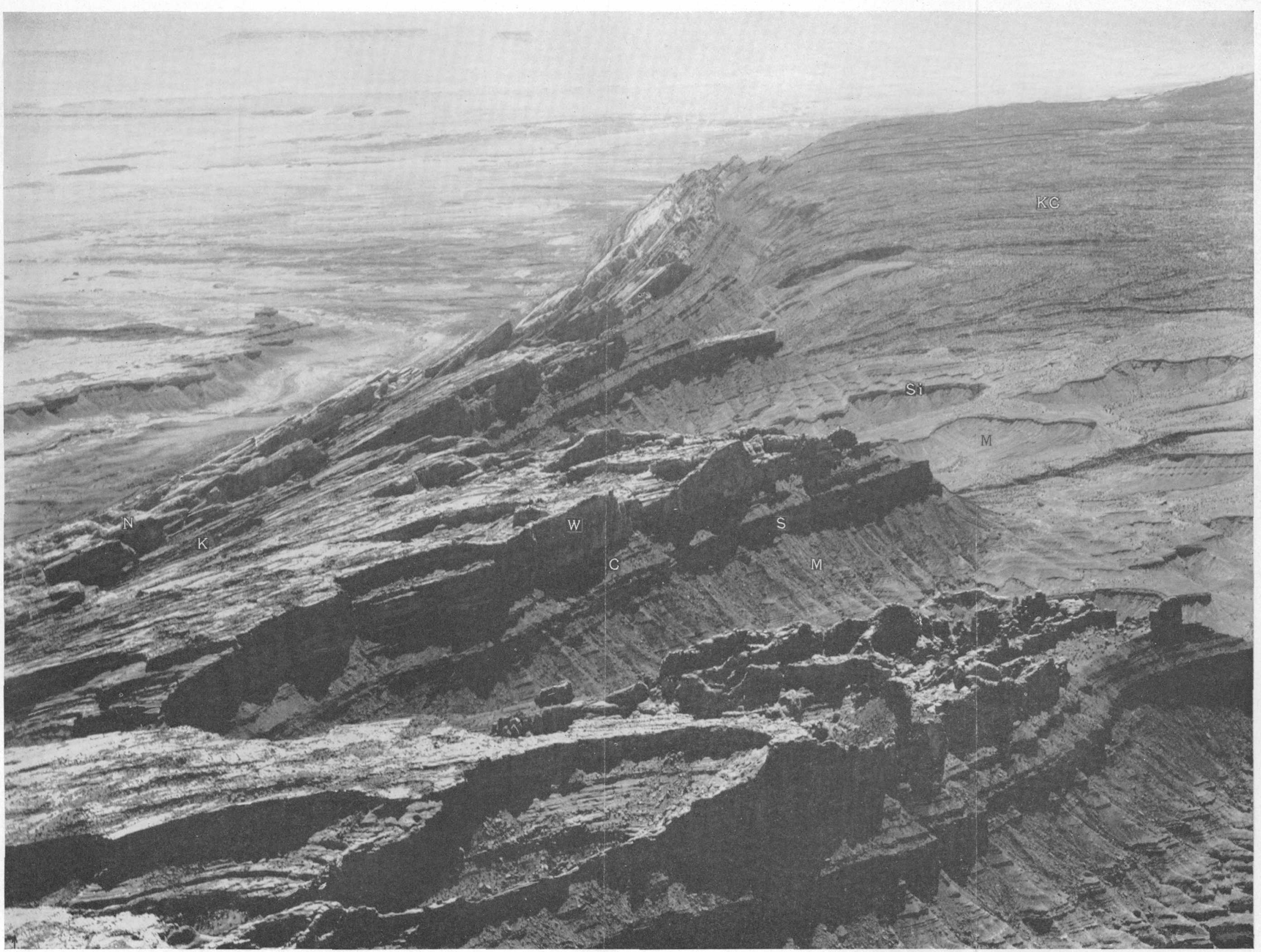

AERIAL VIEW SOUTH ALONG THE REEF FROM BLACK DRAGON CANYON.

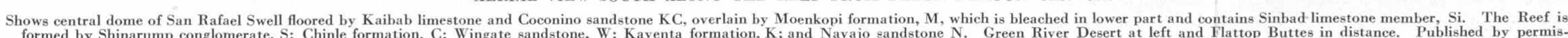

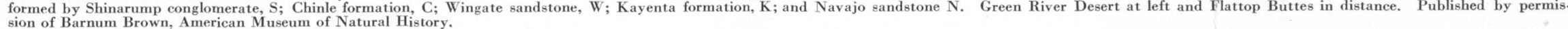


at the Cove, 270 feet at North Trail, and 280 feet at Straight Wash.

The contact of the Kayenta formation with the underlying Wingate sandstone may be unconformable, as suggested by bleaching of the top of the Wingate and slight relief at many localities. At other localities, however, there is a gradual change in bedding and lithology from the massive sandstone of the Wingate to the sandstone typical of the Kayenta. Similarly, at its upper contact there is locally a sharp boundary between typical Kayenta and the massive sandstone of the overlying Navajo, but at most places there is a gradual change in bedding and lithology. The boundaries of the formation were selected more or less arbitrarily to include in the Kayenta all the distinctly bedded sandstones, and precisely the same horizons may not have been selected throughout the area.

Dinosaur tracks and invertebrate fossils were collected from the transition zone between the Kayenta and Navajo in rocks that were mapped as Navajo but might equally well have been considered Kayenta. The tracks and invertebrate fossils were found 2.8 miles nearly due west of Lost Spring at the top of the cliff on the north side of the main fork of Iron Wash where it passes through the Reef. Specimens of the tracks were examined by C. W. Gilmore, and the invertebrate fossils were examined by J. B. Reeside, jr., who reported that they were "Unio, a single elongate species rather unlike any named forms but like specimens from other localities in the Kayenta formation." Neither the tracks nor the invertebrate fossils are helpful in assigning a specific age to the Kayenta. The correlation of the Kayenta formation between the Green River Desert-Cataract Canyon region and its type locality near Kayenta, Ariz., is clearly established by its typical lithology, stratigraphic position, and tracing of the formation across the intervening area.

The irregularly bedded, poorly sorted sediments of the Kayenta were obviously deposited in water, probably by shifting streams. The fossil specimens of Unio collected from the formation in this area and at a locality near $\mathrm{Moab}^{70}$ are a type that lived in fresh water.

\section{NAVAJO SANDSTONE}

The Navajo sandstone is the upper formation of the Glen Canyon group. It crops out extensively on the upland surface in the southern part of the area and is the wall rock of many of the canyons cut into the upland. It is also the principal surface

\footnotetext{
${ }^{70}$ Baker, A. A., Geology and oil resources of the Moab district, Grand and San Juan Counties, Utah: U. S. Geol. Survey Bull. 841, p. 46, 1933.
} 
rock on the east side of the Reef along the flank of the San Rafael Swell. Where it is protected from erosion by a capping of more resistant rocks in the overlying Carmel formation, the Navajo commonly crops out in vertical to slightly rounded faces, which at places form the walls of deep narrow canyons, such as Three Canyons, Horseshoe Canyon, and the canyons of several tributaries of the Dirty Devil River. Where a protective capping is absent the Navajo sandstone tends to form steep rounded slopes, and many of the canyons cut in the Navajo have practically vertical lower walls surmounted by rounded domes. The lower part of the formation commonly crops out in a cliff rising above the bench formed by the underlying Kayenta formation. On the southern part of the upland surface where the Navajo has been largely removed by erosion there are numerous buttes of Navajo, many of which are rounded and resemble large bee hives. (See pl. 10, B.) The intricate topography of the east face of the Reef and much of the serrate crest of the Reef as seen from the east has resulted from the dissection of the upturned edge of the Navajo sandstone. (See pls. 14, 16.)

The Navajo is essentially a homogeneous gray to buff mediumgrained sandstone consisting of subangular to rounded grains of quartz with a few grains of feldspar and ferromagnesian minerals poorly cemented by lime and silica. The sand grains range in size from about 0.02 to 0.5 millimeter with an average diameter of about 0.15 millimeter. Normal bedding planes are rare, but the sandstone is intricately cross-bedded. The occasional lenses of light brown unfossiliferous limestone, as much as 6 feet thick, which are present locally, are more resistant to erosion than the sandstone and form the protective capping on a few small flattopped buttes or mesas. Thin lenticular beds of red to purplish shale are present in the sandstone. The top of a bed of lightbrown sandstone, 1 to 4 feet thick, was mapped as the top of the Navajo because it is related to the Navajo in lithology and topographic expresssion, although it appears to be reworked Navajo sand and probably represents the basal bed of the overlying Carmel formation. Near the top of the Navajo at several localities in the region, especially about 2 miles west of the mouth of Moonshine Canyon and between Straight Wash and the main fork of Iron Wash in the southern part of T. 23 S., R. 13 E., and the northern part of T. 24 S., R. 13 E., the formation contains pitted and ridged pebbles, ${ }^{71}$ which are abundant as residual pebbles on weathered surfaces; the sculpturing of the pebbles is

\footnotetext{
${ }^{71}$ Baker, A. A., Dane, C. H., and Reeside, J. B., Jr., Correlation of the Jurassic formations of parts of Utah, Arizona, New Mexico, and Colorado: U. S. Geol. Survey Prof. Paper 183, pls. 13 and $14,1936$.
} 
typical of the pitted surfaces of some varieties of wind-worn pebbles. Measured thicknesses of the Navajo sandstone are 507 feet at the road crossing of Horseshoe Canyon, 515 feet in Trail Spring Fork of Horseshoe Canyon, 552 feet in Twin Corral Box Canyon, 430 feet in the Reef at Iron Wash, and 420 feet in the Reef at Straight Wash.

The lower boundary of the Navajo is selected somewhat arbitrarily at the base of massive sandstone and at the top of the bedded sandstone that is transitional in lithology from the underlying Kayenta formation. The upper contact marks an abrupt change in lithology, except for the thin bed of reworked sand, as the Navajo is overlain by red shale and sandy limestone of the Carmel formation. The contact has slight local relief. (See pl. 17, A.) It is possible that the Navajo is separated from the Carmel by an unconformity, but it seems more probable that the incursion of the Carmel sea terminated the period of Navajo deposition and that there was no important period of erosion prior to the deposition of the Carmel sediments.

No fossils were found in beds definitely included in the Navajo, but the dinosaur footprints and Unios collected in the Reef on the rim of Iron Wash Canyon were found in beds that are in the transition zone between the Kayenta and Navajo. Although these beds are arbitrarily included in the Navajo, they might equally well be included in the Kayenta.

The Navajo has long been considered by most geologists as a typical sand-dune deposit. The occurrence of wind-worn pebbles in the sandstone tends to substantiate this theory of origin. The occasional thin limestone beds of limited extent probably represent accumulations in ephemeral lakes.

\section{JURASSIC SYSTEM \\ UPPER JURASSIC SERIES \\ SAN. RAFAEL GROUP}

The San Rafael group, which overlies the Navajo sandstone, includes most of the surface rocks of a large part of the Green River Desert extending from north of the San Rafael River nearly to the rim of Happy Canyon, and in the northern part of its area of outcrop it extends from the Reef to the Green River. The type region of the group is the San Rafael Swell ${ }^{72}$ where it includes the Carmel, Entrada, Curtis, and Summerville formations named in ascending order. These formations are all present in the Green River Desert-Cataract Canyon region, but important changes in lithology occur toward the east, particularly in the Carmel and

\footnotetext{
${ }^{72}$ Gilluly, James, and Reeside, J. B., Jr., Sedimentary rocks of the San Rafael Swell and some adjacent areas in eastern Utah: U. S. Geol. Survey Prof. Paper 150, p. 73, 1928.
} 
Entrada. Discussions of the regional correlations, history of nomenclature, origin, and age of the formations, have been published in another report. ${ }^{73}$

\section{CARMEL FORMATION}

The Carmel formation crops out along the San Rafael River in the lower part of its course and is the surface rock on a large part of the upland surface south of the San Rafael River. It also crops out in a narrow strike valley along the east side of the northern part of the Reef. The basal beds of the formation consist of rocks that are resistant to erosion and usually crop out in low cliffs or steep slopes that cap cliffs or rise above rounded surfaces of the underlying massive Navajo sandstone. (See pl. 17, A.) These basal resistant beds are upturned along the foot of the east slope of the Reef where they have been eroded to form a series of V-shaped cusps that are in striking contrast with the background of lighter-colored rocks in the Reef. (See pl. 16.) The greater part of the formation is composed of easily eroded rocks that floor broad areas of slight relief or weather into badlands that extend to the foot of the cliffs formed by the overlying Entrada sandstone. The badland areas support scant vegetation, and the bare red rocks of the formation are a conspicuous feature of the landscape.

The lower part of the Carmel formation in most of the area consists of interbedded greenish-gray, buff, red, or lavender mudstone, sandstone, and fossiliferous limestone. It is distinct from the rest of the formation because of the presence of abundant limestone and sandstone, its cliff and bench-forming topographic expression, and the dull red to lavender of certain beds, which cause this part of the formation to appear darker-colored. This series of beds is 100 feet or more thick in the San Rafael Swell ${ }^{74}$. but thins toward the east and has a maximum thickness of about 70 feet along the Reef on the east flank of the Swell, where the following section was measured:

Navajo sandstone.

Section of the lower cliff-forming part of the Carmel formation along Iron Wash in the SW1/4 sec. 34, T. 23 S., R. $13 E$.

Carmel formation:

Feet

Sandstone, limy, red to gray, thin-bedded, in part ripple-marked and cross-bedded; upper beds form top of low cliff and form a floor for broad benches

Sandstone, red, medium- to fine-grained; in part cross-bedded and red sandy mudstone, which weathers to nodular surfaces.

7 Baker, A. A., Dane, C. H., and Reeside, J. B., Jr., op. cit.

"Gilluly, James, Geology and oil and gas prospects of part of the San Rafael Swell, Utah: U. S. Geol. Survey Bull. 806, pp. 99-102, 1929. 
Limestone, siliceous, greenish-gray to red, oolitic, fossiliferous, interbedded with ripple-marked, red, limy sandstone.

Mudstone, sandy; dull-red, grading upward through brick-red, minutely cross-bedded, ripple-marked limy sandstone to greenishgray siliceous limestone.

Sandstone, buff, medium-grained, friable, lenticularly bedded; seamed with small veins of gypsum.

Mudstone, sandy, dull-red, seamed with small veins of gypsum. 10

66

Traced eastward across the Green River Desert the upper sandstone beds grade into red muddy sandstone or mudstone that is indistinguishable from overlying beds. Near the eastern margin of the area of outcrop in the vicinity of the mouth of the San Rafael River the lower bluff-forming beds in the Carmel are about 45 feet thick; they locally contain thin beds of limestone but consist principally of red to gray sandstone, as shown in the section (p. 72) measured near the mouth of Moonshine Canyon in sec. 9, T. 24 S., R. 16 E. Still farther east, beyond Green River, these beds are not distinguishable as a separate part of the formation..$^{75}$ Near the southeastern and southern margins of the area of outcrop on the Spur and in the vicinity of Twin Corral Flats and Robbers Roost Spring the bluff-forming beds at the base of the Carmel are only 10 to 20 feet thick and consist of purplish-red sandstone.

Above the basal bluff-forming beds the Carmel consists dominantly of brownish-red silty sandstone and mudstone with abundant interbedded red to gray shale, irregularly bedded red, buff, or gray sandstone, and a few thin beds of red to gray limestone. Near the Reef the basal bluff-forming beds are overlain by fossiliferous gray to greenish-gray shale, mudstone, and platy sandstone that is 58 feet thick at Black Dragon Canyon, 61 feet thick about 1 mile north of Straight Wash, and 50 feet thick in Iron Wash in the northern part of T. 24 S., R. 13 E.; this unit of gray rocks decreases in thickness toward the east and is not a conspicuous part of the formation farther east in the area. The gray unit presumably grades laterally into brownish-red rocks. The formation contains abundant gypsum in the central part of the area that extends approximately from Iron Wash and the San Rafael River south to the Biddlecome Ranch and from the San Rafael Reef east to Moonshine Canyon and Antelope Valley. The gypsum is interbedded with the red beds, but at most outcrops the bedding is so disturbed that the rock appears to be an intimate intermixture of white gypsum and red fine-grained clastic sediments with

\footnotetext{
${ }^{25}$ McKnight, E. T., Geology of the area between the Green and Colorado Rivers, Grand and San Juan Counties, Utah: U. S. Geol. Survey Bull. 908, 1940 [1941].
} 
little or no bedding apparent. In general, the gypsum is more abundant in the upper part of the formation but it is present, locally, in all parts above the basal bluff-forming beds. Water in springs emanating from the Carmel in the part of the area where the formation is gypsiferous is highly mineralized and is not suitable for human consumption. The following sections show the lithology of the formation in different parts of the area, but none of the sections is representative of the formation where it contains abundant gypsum.

Section of the Carmel formation measured near the mouth of Moonshine Canyon in sec. 9, T. 24 S., R. 16 E.

Entrada sandstone.

Carmel formation:

Sandstone, muddy, red; thin-bedded, but bedding is undulatory; contains few thin beds of current-marked limy gray sandstone; grades downward into dark-red sandy shale.

Shale, sandy, red interbedded with yellow-weathering gray limy sandstone, fragments of which litter the surface and form a dirty yellow band

Limestone, gray, weathers yellow...

Mudstone and soft sandstone with a few thin beds of ledge-forming sandstone, brick-red to chocolate-brown

Limestone, sandy, reddish-lavender, gray-weathering..

Sandstone, red-brown, irregularly bedded, platy to massive, ripplemarked.

Sandstone, muddy, red-brown, weathers to rounded surfaces formed by spalling, light-gray band 1 foot thick at top.

Sandstone, blue-gray, weathers red, fine-grained, thin-bedded, ripple-marked, contains small masses of crystalline calcite; forms top of bluff.

Shale and muddy sandstone, red...

Sandstone, buff to yellow, medium- to coarse-grained, ledge-forming

Sandstone, muddy, red, nodular-weathering

Sandstone, gray to lavender, medium-grained, thin-bedded; contains chert nodules.

Navajo sandstone.

Section of Carmel formation at Robbers Roost Spring

Entrada sandstone.

Carmel formation:

Shale, red and gray and silty red sandstone with some interbedded gypsum and lenticular bodies of red to light-brown sandstone as much as 30 feet or more thick and 200 feet in diameter.

Gypsum, gray, massive; occurs in pockets and grades laterally into silty red sandstone.

Sandstone, silty, red, irregularly bedded.

Sandstone, red to lavender, thin-bedded, cliff-forming.

Navajo sandstone. 
Section of Carmel formation in the Reef at the mouth of Black Dragon Canyon in sec. 6, T. 22 S., R. $14 E$.

Entrada sandstone.

Carmel formation:

Sandstone, mudstone, and shale, red

Sandstone, shaly sandstone and mudstone, greenish-gray to buff;

thin limy sandstone, 33 feet above the base is bench-forming.........

Limestone, gray, fossiliferous, bench-forming.

Sandstone, red-brown

Navajo sandstone.

230

The Carmel is about 230 feet thick at Straight Wash and Black Dragon Canyon along the Reef but decreases in thickness progressively toward the east and southeast. It is 129 feet thick near the mouth of Moonshine Canyon in the northern part of T. 24 S., R. 16 E., 140 feet at the head of Keg Spring Canyon, 170 feet on the west side of Horseshoe Cayon at the road crossing, 122 feet at Robbers Roost Spring, 92 feet at Goat Flats east of Robbers Roost Flats, and 85 feet near the southern limit of the Carmel outcrop on The Spur.

The contact of the Carmel with the underlying Navajo sandstone is sharp. At many places typical Navajo sandstone is overlain by a 1- to 4-foot bed of yellow to brown sandstone, which was mapped with the Navajo but probably represents reworked Navajo sandstone deposited as the initial stage of Carmel deposition; the bed of sandstone locally contains pebbles of chert one-fourth inch or less in diameter. At other places there is minor local relief at the contact with red sediments of the Carmel deposited in broad shallow depressions or channels in the Navajo (pl. 17, $A$ ) ; the maximum depth of the channels probably does not greatly exceed 5 feet.

These features of the contact are suggestive of an unconformity at this horizon. However, such features might be expected if the Carmel sea advanced across a large area of low relief floored by unconsolidated Navajo dune sand. The encroaching sea would of course considerably modify the original dune surface and might even obliterate its original irregularities entirely, but other irregularities would be formed on the surface of the loose sand by wave and current action. It is, therefore, uncertain whether the NavajoCarmel contact represents a stratigraphic break and erosion interval or whether there was continuous deposition and the contact marks a change from eolian to shallow-water marine conditions. The writer is inclined to favor the second interpretation.

The upper contact of the Carmel formation is extremely irregular. At most localities the contact between the shale and siltstone of the Carmel and the massive sandstone of the overlying Entrada 
is sharp but has local relief of as much as 75 feet. Dissection of the massive Entrada sandstone, filling the depressions, leaves remnants at some localities as a series of small knobs rising above shale slopes far below the stratigraphic position of the base of the Entrada in nearby outcrops, as on the east side of Moonshine Canyon; the impression is given that the sandstone knobs are ovate bodies that have weathered out of the Carmel and are older than Entrada. (See fig. 3.) The contact at other localities appears grada-

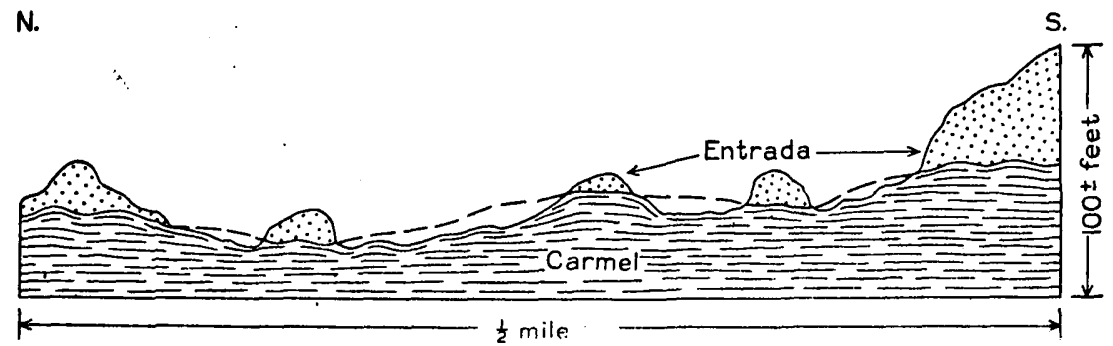

Figure 3.-Diagrammatic cross section of the Carmel-Entrada contact on the east side of Moonshine Canyon.

tional from sandy red beds in the Carmel to the massive sandstone of the Entrada, but the bedding is crinkled and contorted both in the transitional beds and in the basal part of the overlying sandstone. (See pl. 17, B.) The abrupt change in lithology at the contact in most of the area indicates an abrupt change in the conditions of sedimentation and, considered in connection with the local relief at the contact, is suggestive of an unconformity at this horizon. However, the contorted bedding both above and below the contact and the relief at the base of the Entrada in parts of the area and elsewhere in southeastern Utah appear to be due to plastic adjustment and gliding of the water-soaked sandy mud of the Carmel under differential loading; the movement probably occurred in the unconsolidated or partly consolidated sediment during or shortly after deposition. ${ }^{76}$ Thus, there does not appear to have been a significant lapse of time between the deposition of the Carmel and Entrada formations. The gradational contact at some localities also seems to indicate essentially continuous deposition.

The fossils contained in the Carmel formation show that it is of Upper Jurassic age. Specimens in numerous collections from the San Rafael Swell are listed by Gilluly and Reeside; ${ }^{77}$ those in two additional collections from the Carmel in the vicinity of The Reef have been identified by J. B. Reeside, Jr., as follows :

${ }^{76}$ Dane, C. H., Geology of the Salt Valley anticline and adjacent areas, Grand County Utah: U. S. Geol. Survey, Bull. 863, pp. 99-100, 1935 [1936].

"Gilluly, James, and Reeside, J. B., Jr., Sedimentary rocks of the San Rafael Swell and some adjacent areas in eastern Utah: U. S. Geol. Survey Prof. Paper 150, p. 75, 1928. 
Lot 16202. Carmel limestone about 40 feet above the base of the formation northwest of Lost Spring in the NW1/4 sec. 19, T. 24 S., R. 13 E.

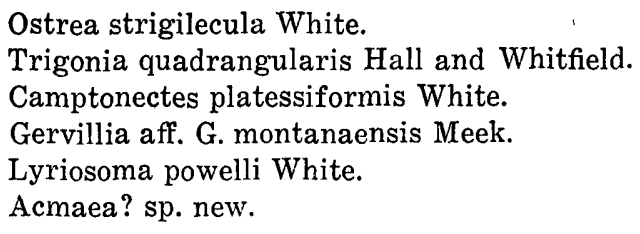

Lot 15551. Carmel formation from greenish-gray sandstone about 96 feet above the base of the formation on the east side of Iron Wash in the SE $1 / 4$ sec. 34, T. 23 S., R. 13 E.

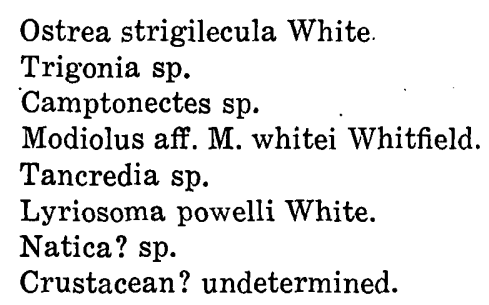

Another collection was obtained from a thin oolitic limestone interbedded with gypsiferous beds in the upper one-third of the Carmel about 500 feet east of Swazys seep. A faunal list for this collection is not available, but Reeside reports that it contains typical Carmel forms.

The marine origin of parts of the Carmel formation is shown by the contained fossils. Near the Reef, marine fossils have been found in the basal bluff-forming beds, in the overlying greenishgray sandstone and shale, and also in the upper part of the formation, above the greenish-gray beds, in limestone interbedded with gypsum. Although no fossils have been found in the red rocks of which the formation is largely composed, they probably were deposited in shallow water near the eastern shore of the sea. The gypsum probably was formed in lagoons along the shore.

\section{ENTRADA SANDSTONE}

The Entrada sandstone crops out extensively in the central part of the area in the vicinity of the Flattop Buttes, in the valley of the San Rafael River, and on stream divides extending south from the river. With the exception of several relatively small buttes and mesas, it has been eroded from all the area east and south of Horseshoe and Twin Corral Box Canyons. Toward the north, a few miles north of Iron Wash and the lower San Rafael River, it dips below younger rocks in T. 24 S., Rs. 14 to 16 E., but along the east foot of The Reef it crops out in a narrow strike valley, which extends to the northern boundary of the area. The upper few feet of the formation crops out in a small isolated exposure on the west bank

$697241-46-6$ 
of the Green River north of a fault in sec. 34, T. 21 S., R. 16 E. The only rocks younger than Entrada that are exposed on the great area of upland surface included within the limits of outcrop of the formation are widespread surfical deposits of caliche and gravel and a few small remnants of other formations that crop out in isolated buttes and mesas.

Outcrops of the Entrada sandstone usually form either steep relatively smooth bluffs or cliffs composed of a series of rounded ledges, which rise above the benches formed by the Carmel formation. At places the basal beds of the Entrada form unscalable cliffs that have very irregular courses around innumerable spurs and reentrants. Near the mouth of the San Rafael River and east of the Flattop Buttes practically the entire thickness of the Entrada is exposed in conspicuous high broken cliffs cut by numerous short more or less precipitous walled canyons. Most of the formation tends to weather into rounded domes, but locally knobs, spires, low. turrets, pedestals, and other irregularly shaped products of erosion are prominent features of the outcrop. Flat-topped buttes, which are very abundant on the upland surface in the area of Entrada outcrop, are the result of erosion of the sandstone below a relatively resistant capping of much younger cemented gravel or caliche. Large areas of comparatively low relief are covered by thick deposits of loose sand which is derived from disintegration of the Entrada and forms constantly shifting dunes.

The Entrada consists principally of gray, tan, or orange-brown sandstone with subordinate reddish-brown sandstone and occasional beds of red shale. It is thick-bedded and many of the bedding planes are continuous over large areas, but in detail some of the bedding planes are undulatory and have local relief of 20 feet or more; locally the bedding is contorted as if by slight plastic flow. (See pl. 17, C.) The lighter-colored sandstones are generally tangentially cross-bedded and consist of lime-cemented medium to fine-grained, rounded to subrounded grains of fairly well sorted material. The interbedded reddish-brown sandstone differs from the lighter beds principally by having more regularity in bedding and less abundance of cement, and by the presence of silty material; these red beds, which are conveniently described as earthy sandstones, form nodular surfaces and smooth slopes. Near the Reef in the northern part of the area, the formation includes a somewhat greater proportion of the darker, reddish-brown sandstone, but toward the southeast it grades into less silty lightercolored sandstone. A zone of earthy sandstone 60 to 100 feet thick at the top of the formation persists across the area but is the only thick earthy sandstone unit that extends beyond Green River; this 
unit disappears a few miles east of the river. ${ }^{78}$ The thickness of the Entrada is 405 feet, as shown by a section measured by Gilluly and Reeside $\mathrm{e}^{79}$ at the mouth of Black Dragon Canyon, 445 feet measured near Iron Wash in sec. 10, T. 24 S., R. 13 E., where the top could be determined only approximately; 420 feet and 435 feet measured near the San Rafael River in the eastern part of T. 24 S., R. 15 E., and at a nearby locality in the western part of T. 24 S., R. $16 \mathrm{E}$.; and 460 feet measured east of the Flattop Buttes at the head of Dugout Creek.

The following sections show the lithology of the formation and illustrates changes in the lithology across the area.

Section of Entrada sandstone measured in sec. 10, T. 2.4 S., R. 13 E. Entrada sandstone:

Top eroded but section approximately complete.

Sandstone, red, earthy, massive

Sandstone, buff to gray, medium-grained, soft, thick-bedded, crossbedded

Sandstone, red, earthy, with some interbedded red shale and several

thin ledge-forming beds of brown, buff, or gray medium- to finegrained sandstone

Sandstone, buff to gray, friable, medium-grained, cross-bedded.

Carmel formation.

Section of Entrada sandstone measured south of San Rafael River in sec. 18, T. 24 S., R. 16 E.

Curtis formation: Sandstone, gray, brown-weathering, ledge-forming:

Unconformity.

Entrada sandstone:

Sandstone, dark-red, earthy, nodular weathering.

Sandstone, buff to tan, grayish in discontinuous bands possibly due to bleaching along bedding planes, more or less distinctly bedded

Shale, red, forms bench

Sandstone, tan, cross-bedded, occasional ripple marks, has few thin lenses of shale, numerous large irregularly shaped hematite-rich bodies of sandstone in lower 150 feet; bedding indistinct; base irregular.

Carmel formation.

${ }^{78}$ McKnight, E. T., Geology of area between Green and Colorado Rivers, Grand and San Juan Counties, Utah: U. S. Geol. Survey Bull. 908, 1940 [1941].

${ }^{79}$ Gilluly, James, and Reeside, J. B., Jr., Sedimentary rocks of the San Rafael Swell and some adjacent areas in eastern Utah: U. S. Geol. Survey Prof. Paper 150, pp. 105-106, 1928. 
Section of Entrada sandstone measured about 2 miles east of Sweetwater Spring at the head of Dugout Creek

Curtis formation.

Unconformity.

Entrada sandstone:

Sandstone, dull red-brown, earthy, with some thin beds of gray

ledge-forming, blocky-weâthering sandstone..
Sandstone, light-brown, splotched with gray, ledg 105

Sandstone, light-brown, earthy, massive, weathers in rounded knobs and large boulder-shaped masses

Sandstone, light-brown, medium- to fine-grained, sparsely splotched with gray, with prominent gray band in lower part.

Sandstone, light-brown, medium- to fine-grained, massive, crossbedded, thick-bedded, weathers in rounded steps, top conspicuously marked with white splotches; ripple-marked in places

Sandstone, tan to light-brown, top nearly white, medium-grained, massive, ledge-forming; mud cracks in the base of this ledge at a nearby locality.

Sandstone, light-brown, medium- to fine-grained 12

Sandstone, light-brown, earthy, medium- to fine-grained

Sandstone, dark red-brown, thin-bedded, interbedded with dark-red shale.

Sandstone, light reddish-brown, medium-grained, massive, crossbedded prominently marked with rows of solution cavities parallel to bedding, forms conspicuous ledge

Sandstone, red-brown, interbedded with white medium-grained sugary sandstone and thin beds of red shale

Sandstone, light reddish-brown, massive, weathering into rounded forms, interbedded with nodular-weathering reddish-brown earthy sandstone; forms turrets and spires

Sandstone, white, medium-grained, sugary, ledge-forming.

Sandstone, $\tan$ to light-brown, medium- to fine-grained, massive, cross-bedded.

Sandstone, white, medium- to fine-grained, massive, ledge-forming-

Sandstone, tan, medium-grained, massive, cross-bedded.

Sandstone, white, medium-grained, massive, cross-bedded, ledgeforming

Sandstone, tan, medium-grained, massive, cross-bedded, contains lenses of grit: irregular base

Carmel formation.

The contact of the Entrada with the underlying Carmel formation is locally very irregular but, as described on page 74, there appears to have been essentially continuous deposition through Carmel and Entrada time. At its upper boundary the Entrada is overlain unconformably by the Curtis formation. The contact at most places is marked by a sharp lithologic boundary between the reddish-brown earthy sandstone of the Entrada and coarsergrained greenish-gray ledge-forming sandstone of the Curtis but 
locally, as at the north end of Big Flattop Butte, the color change is gradual and the basal beds of the Curtis are similar in lithology to the underlying Entrada. (See pl. 18, A.) The contact usually exhibits either considerable relief or slight angular discordance with beveling of Entrada strata. At many places the basal beds of the Curtis have anomalous dips of as much as $15^{\circ}$ that have no uniformity of direction; the dips appear to indicate a great number of low folds. Such folds are present only in the area of outcrop of the Curtis formation, and their absence in areas of outcrop of older beds is strong evidence against an interpretation that they are of diastrophic origin. The irregularities of dip may be of similar origin to those of the base of the Entrada (pp. 73-74), which are interpreted as adjustments to plastic flow of unconsolidated sediments under differential loading; the silty beds at the top of the Entrada are not greatly different in composition from much of the Carmel and presumably would yield to pressure in similar ways. Some of the irregular dips in the Curtis may be initial dips because of deposition upon an irregular or rolling Entrada surface. Beveling of Entrada strata at the contact does not appear to have any relation to regional folding of the Entrada or uniformity of direction of beveling. The writer is of the opinion that the occasional occurrence of slight angular discordance resulting from the beveling of inclined Entrada strata is due to the planation of undulatory bedding planes in the upper earthy facies of the Entrada and does not reflect diastrophic movement between Entrada and Curtis time. Although this unconformity is distinct and has been followed from the San Rafael Swell eastward beyond Green River, its importance as an indication of a prolonged time break at this horizon may well be questioned in view of the stratigraphic relationships east of Green River. As described in other reports, ${ }^{80}$ the Curtis disappears east of Green River at least in part by gradation into beds of Summerville lithology, which in turn intertongue with the Entrada sandstone so that the unconformity between the Curtis and Entrada in the vicinity of the Green River is at a horizon that, farther east in Utah, is in the midst of an essentially homogeneous Entrada formation; it is possible that westward from this area the unconformity has greater significance.

The correlation of the Entrada sandstone of the Green River Desert-Cataract Canyon region with the nearby type locality of the formation in the San Rafael Swell ${ }^{81}$ is clearly established by de-

\footnotetext{
${ }^{80}$ McKnight, E. T., Geology of area between Green and Colorado Rivers, Grand and San Juan Counties, Utah : U. S. Geol. Survey Bull. 908, 1940 [1941]. Baker, A. A., Dane, C. H., and Reeside, J. B., Jr., Correlation of the Jurassic formations of parts of Utah, Arizona, New Mexico, and Colorado: U. S. Geol. Survey Prof. Paper 183, 1936.

${ }^{81}$ Gilluly, James, and Reeside, J. B., Jr., Sedimentary rocks of the San Rafael Swell and some adjacent areas in eastern Utah: U. S. Geol. Survey Prof. Paper 150, p. 76, 1928.
} 
tailed tracing and mapping in the intervening area, by lithologic similarity, and by its stratigraphic position between the underlying Carmel and the overlying Curtis formations. Although no fossils have been found in the Entrada sandstone, both the Carmel and Curtis formations contain fossils of Upper Jurassic age, and the age of the Entrada is thereby determined to be Upper Jurassic.

The Entrada sandstone appears to be in part wind-laid and in part water-laid. Most of the light-colored clean sandstones that make up the greater part of the formation in the eastern part of the area exhibit few normal bedding planes but are cross-bedded with tangential laminae. These beds closely resemble the Navajo sandstone and are believed to have a similar origin; the origin of the Navajo is generally ascribed to wind deposition. Some of the lighter-colored sandstones and the red earthy sandstone and shale that are interbedded with the massive beds of clean sandstone exhibit more regular bedding and are obviously water-laid. The occurrence of mud cracks shows that the surfaces of these waterlaid beds were occasionally exposed to the air. The increase in percentage of earthy sandstones northwestward in the Entrada and the apparent position of the formation as a marginal facies of wholly marine rocks occurring farther north in Wyomings2 suggest that the earthy beds in the Green River Desert region are of nearshore marine origin. The position of the shore line must have oscillated during the deposition of the beds that are considered to represent alternating marine and continental conditions. Regularly bedded light-gray sandstones that are distinctive horizon markers beneath red beds in certain parts of the area, particularly east of the Flattop Buttes, may represent the transgressive shore lines. Desert sand-dune conditions probably prevailed on the land bordering the sea toward the south and east:

\section{CURTIS FORMATION}

The Curtis formation, which overlies the Entrada sandstone, is found principally in the northern part of the area. It crops out at the surface along a narrow belt extending from the bank of the Green River, a few miles north of the mouth of the San Rafael River, westward to the flank of the San Rafael Swell, thence northward to the north boundary of the area. North of the main belt of outcrop there is a small isolated exposure on the north side of a fault in sec. 34, T. 21 S., R. 16 E. It has been eroded from the area south of the main belt of outcrop except for small remnants on Gruver's Mesa, a small outlier on the downthrown side of a fault

\footnotetext{
${ }^{22}$ Baker, A. A., Dane, C. H., and Reeside, J. B., Jr., Correlation of the Jurassic formations of parts of Utah, Arizona, New Mexico, and Colorado: U. S. Geol. Survey Prof. Paper 183, p. 54, 1936.
} 
in the eastern part of T. 24 S., R. 13 E., and several outliers near the Emery-Wayne County line, including the Flattop Buttes. The basal beds of the Curtis are normally more resistant to erosion than the underlying Entrada and nearly everywhere form a low ledge. The upper beds commonly form the floor for a broad bench of low relief that extends to the base of the slope formed by the overlying Summerville formation.

The Curtis formation is composed principally of interbedded glauconitic sandstone and shale, and the general color is greenish gray in contrast to the red of the overlying and underlying formations. The sandstones are greenish gray to buff and pale red, in part weathering brown, and range from coarse- to fine-grained and from clean to silty sand. Some beds, especially in the lower part of the formation, are massive but are irregularly bedded and form discontinuous ledges; the bedding of most of the formation is thin and regular. Ripple marks are abundant in the sandstone and many of the beds show cross-bedding. The interbedded shale is greenish gray to red brown and lavender and most of it is sandy; in general, the greenish-gray shale is more characteristic of the lower part of the formation and beds of red-brown sandy shale become more numerous toward the top. The shale and shaly sandstone beds locally contain abundant red chert as small aggregates of rounded to angular particles cemented into more or less platy masses which weather out of the enclosing rock and at many places form a conspicuous coating on bare gray rock surfaces. At some localities the formation contains geodes several inches in diameter composed of red siliceous crusts surrounding long slender blades of crystalline celestite - strontium sulfate. Gypsum is present throughout the formation at the Flattop Buttes, where it occurs interbedded with thin regularly bedded greenish-gray shale and shaly sandstone. (See pl. 18, A.) It occurs as small rounded to ovate bodies sparingly present in the lower part but increasing in abundance toward the upper part of the formation, where they form almost continuous concretionarylike beds 1 foot thick and culminate in a bed of massive gypsum 6 feet thick; the gypsum is white to pink or flesh-colored. Thin beds of gypsum also are present in the Curtis formation at a few other localities in the area. Thin beds of gray sandy limestone were observed at one locality.

The following sections illustrate the lithology of the Curtis formation at three localities in the area. 
Section of Curtis formation measured on north side of knoll in secs. 14 and 23, T. 24 S., R. 13 E.

Summerville formation:

Curtis formation:

Shale, greenish-gray, with some beds of gray sandstone and at the top a band of geodes composed of limy or siliceous crusts surrounding blades of crystalline celestite.

Sandstone, greenish-gray, thin-bedded, platy, cross-bedded, with greenish-gray, subordinate lavender, and sandy shale and a few thin beds of brown-weathering gray sandy limestone..

Sandstone, gray, massive to irregularly bedded, forms bench

Unconformity.

Entrada sandstone.

Section of Curtis formation on the north side of the San Rafael River in sec. 14, T. 23 S., R. 14 E.

Summerville formation.

Curtis formation:

Sandstone and shale, gray, with some lavender and red shale, thin and regularly bedced; grades upward into the Summerville formation and contact is arbitrary.

Sandstone, gray, weathers brown, medium-grained, thin-bedded, ripple-marked, interbedded with gray shaly sandstone and shale; shaly beds contain geodes with red siliceous crusts lined with blades of celestite crystals.

Shale, gray; sandy

Sandstone, light-gray, weathers light-brown, fine-grained, thinbedded, current-marked, with occasional thin beds of lavenderred shale.

Unconformity.

Entrada sandstone.

Section of the Curtis formation on the west bank of Green River in sec. 34, T. 21 S., R. 16 E.

Summerville formation.

Curtis formation:

Sandstone, gray, fine-grained, thin-bedded, platy, with thin beds of lavender-red shale; contains abundant red chert as ixresulax

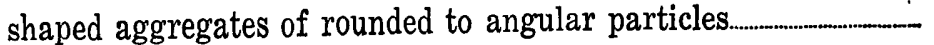

Shale, red to lavender, contains red chert as above

Sandstone, buff, fine-grained, thin-bedded, interbedded with chocolate-brown to red-brown shale and forming a tan slope similar to slopes formed by the Summerville formation.

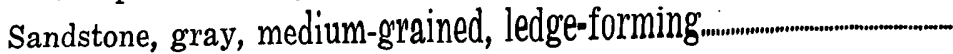




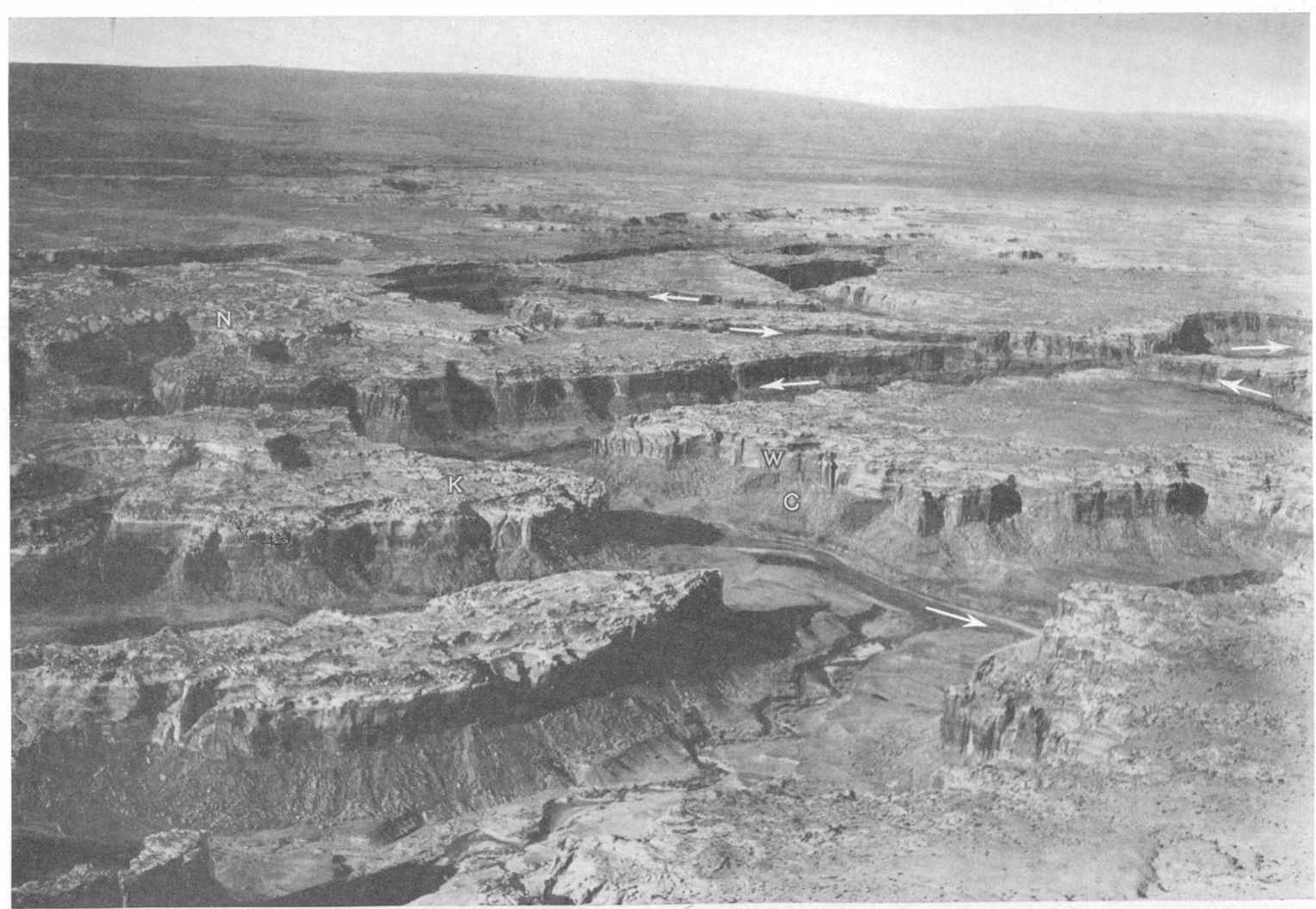

AERIAL VIEW UPSTREAM OF LABYRINTH CANYON IN VICINITY OF THE BOWKNOT.

Shows lower sloping canyon walls formed by Chinle formation, C; precipitous cliffs of Wingate sandstone, W; broad benches floored by Kayenta formation, K; and low cliff of Navajo sandstone. Mouth of Horseshoe Canyon in foreground, part of great eastward loop of the Bowknot at right (direction of flow of river marked by arrows), and Green River Desert in background. Photograph by National Park Service. 


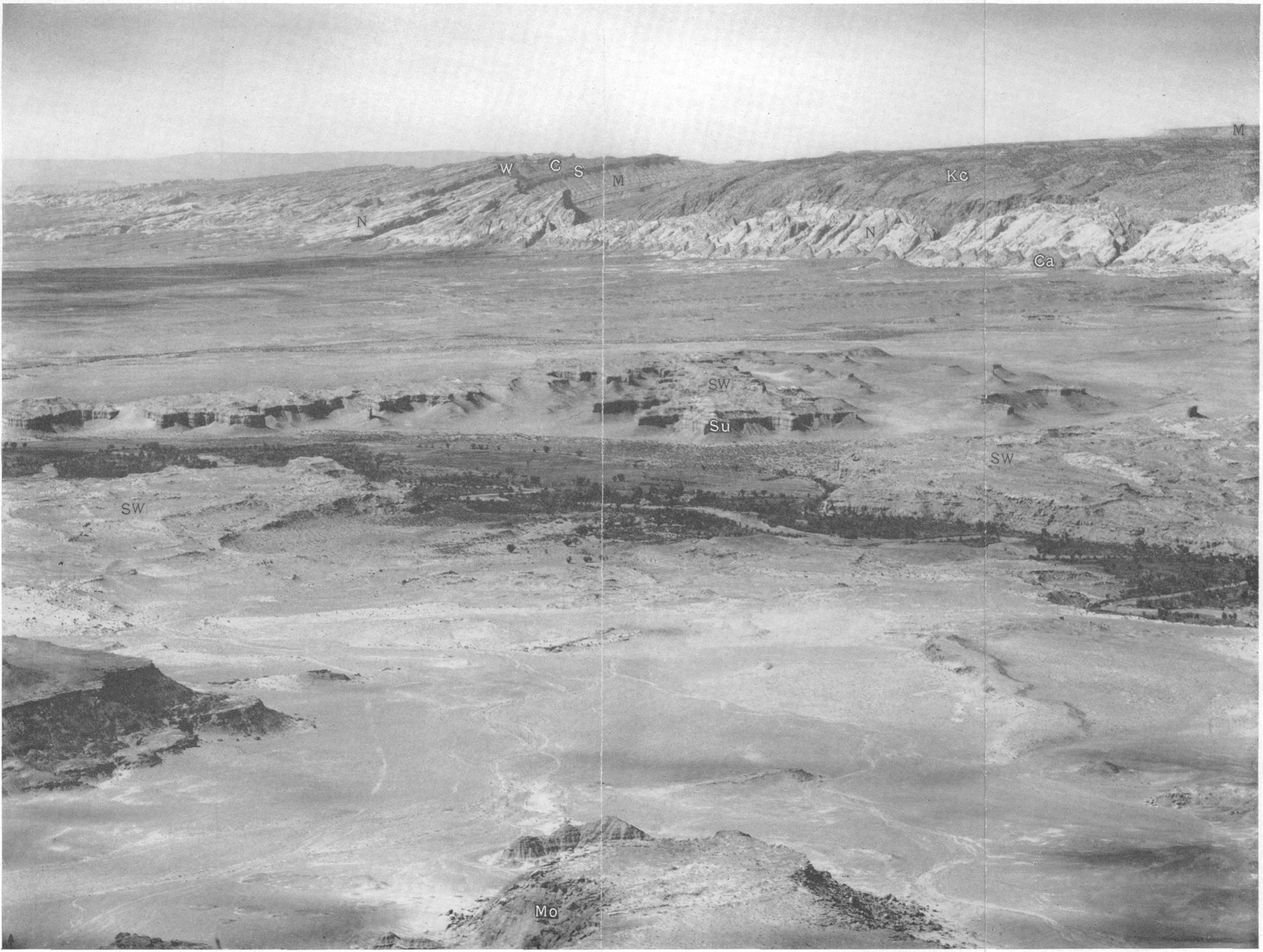

AERIAL YIEW OF EAST FRONT OF SAN RAFAEL SWELL SOUTH OF SAN RAFAEL RIVER.

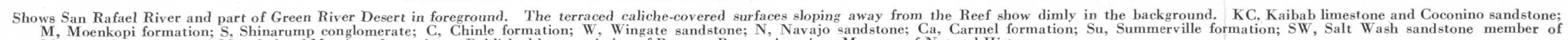
Morrison formation; and Mo, shale of Morrison formation. Published by permission of Barnum Brown, American Museum of Natural History. 


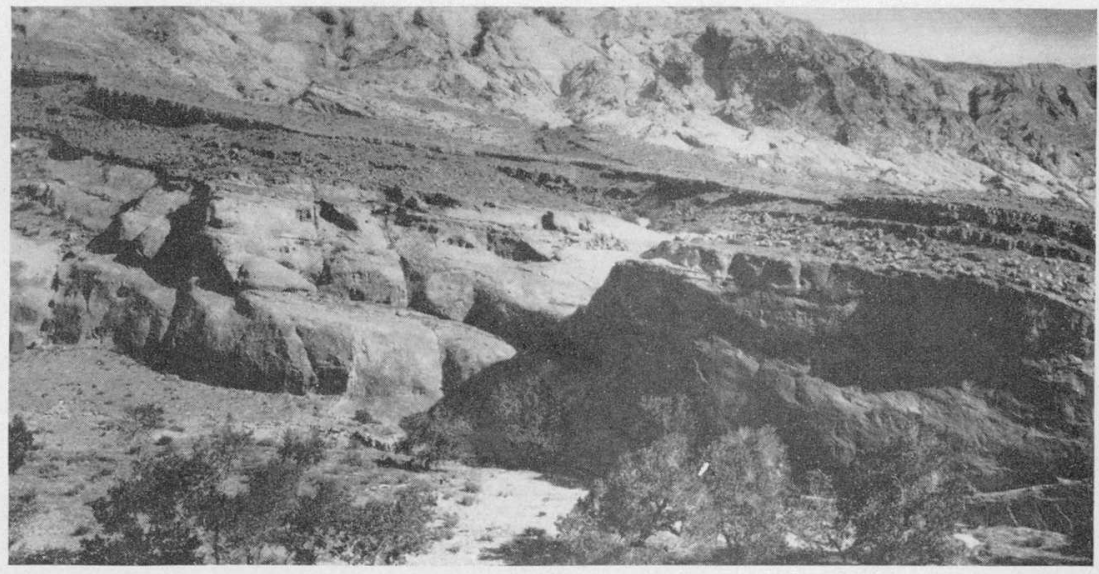

A. BASAL LIMY BEDS OF THE CARMEL FORMATION RESTING UPON SLIGHTLY IRREG. ULAR SURFACE OF THE NAVAJO SANDSTONE AT STRAIGHT WASH.

In background, Navajo sandstone and lower part of Carmel formation are abruptly upturned along the Reef.

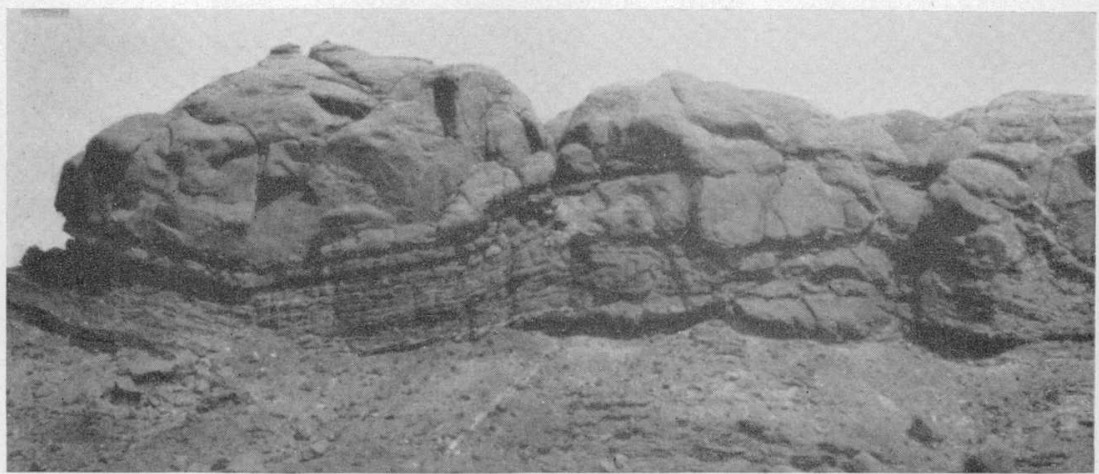

B. CONTACT BETWEEN CARMEL FORMATION AND OVERLYING ENTRADA SANDSTONE ABOUT 4. MILES SOUTHWEST OF MOUTH OF SAN RAFAEL RIVER.

Bedding at the contact is irregular and contorted. Photograph by James Gilluly.

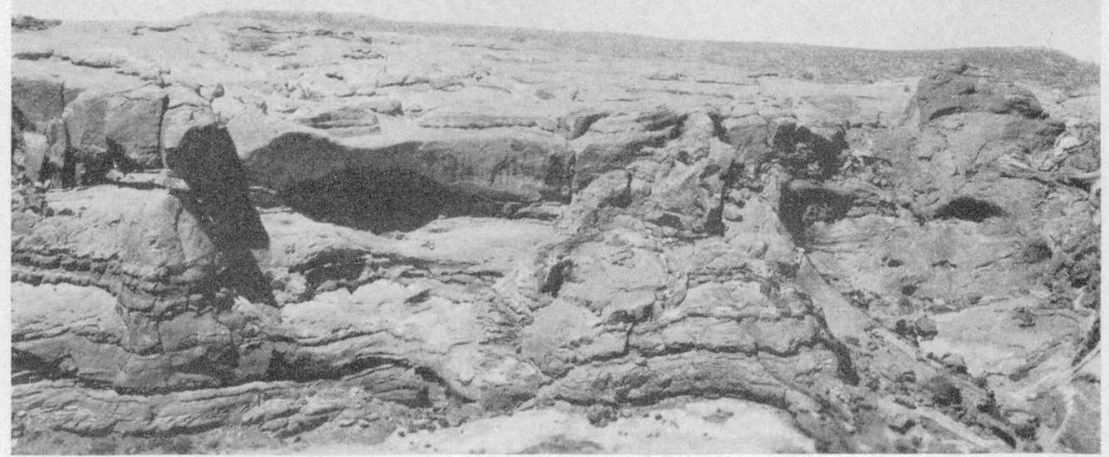

C. CONTORTED BEDDING IN ENTRADA SANDSTONE HALF A MILE WEST OF CABIN SPRING. 


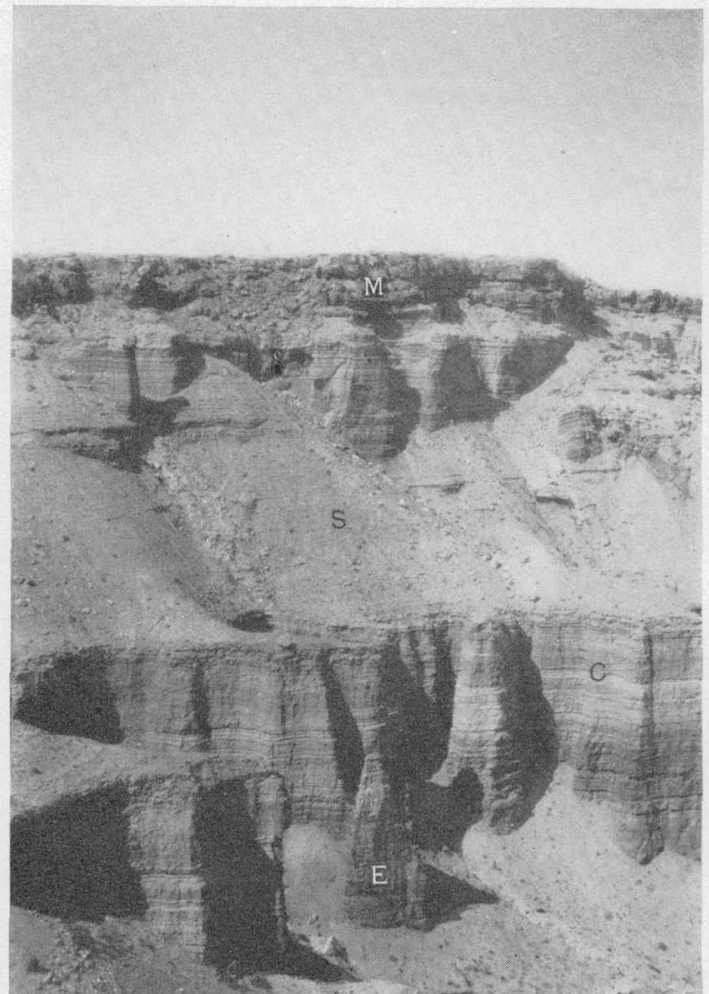

30

A. NORTH POINT OF BIG FLATTOP BUTTE.

E. Entrada sandstone; C, Curtis formation; S, Summerville formation; M, lower part of Salt Wash sandstone member of the Morrison formation.

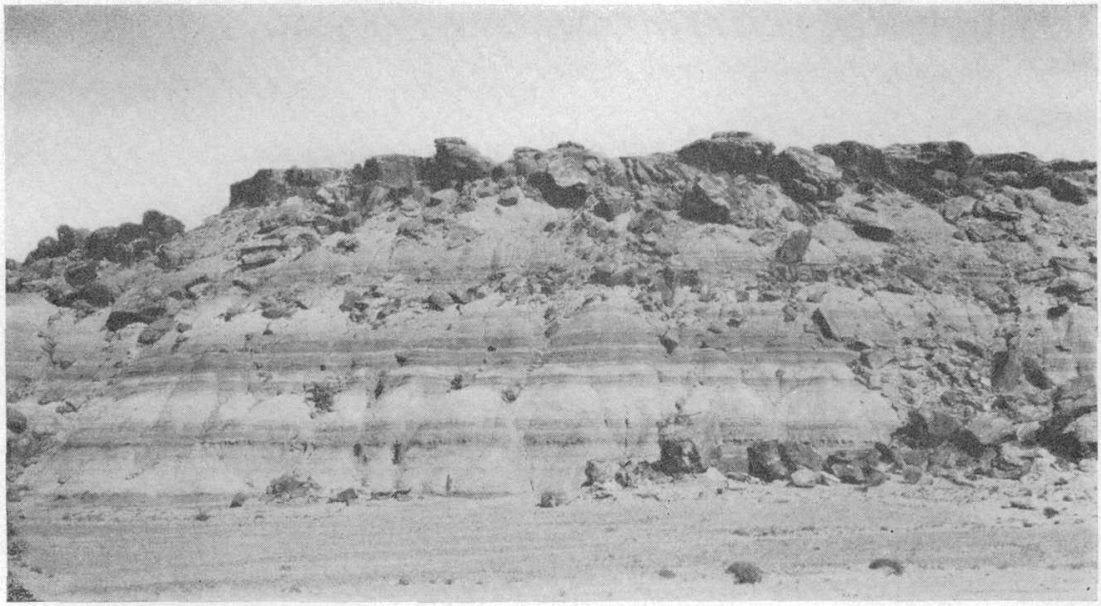

$B$. BANDED VARIEGATED SHALE IN UPPER PART OF THE MORRISON FORMATION, ALONG GREEN RIVER-HANKSVILLE ROAD ABOUT 2 MILES NORTH OF SAN RAFAEL RIVER.

Ledge at top of slope is formed by a bed of siliceus sandstone near top of Morrison formation. 
The thickness of the Curtis formation decreases more or less progressively toward the south and east, as shown by the following measurements :

Smith Cow camp at the southwest corner of T. 20 S., R. 14 E.

North of the San Rafael River near the Tidwell Ranch in sec. 33, T.

21 S., R. 13 E.

235

North side of knoll in secs. 14 and 23, T. 24 S., R. 13 E.

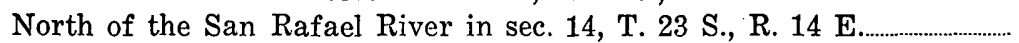

Bank of Green River in sec. 34, T. 21 S., R. 16 E.

Near mouth of the San Rafael River in sec. 20, T. 23 S., R. $16 \mathrm{E}^{83}$

East end of Big Flattop Butte.

North end of Big Flattop Butte.

The Curtis formation rests unconformably upon the Entrada sandstone, as described on page $\mathbf{7 9}$, and is conformably overlain by the Summerville formation. The contact between the Curtis and the Summerville is abitrarily placed nearly everywhere at an indefinite boundary between dominantly gray and dominantly red beds, which otherwise are of similar lithology. At a few localities the color boundary is fairly sharp and can be selected precisely or determined within a few feet, but at most localities there is a series of beds that may exceed a thickness of 30 feet through which there is a progressive upward increase in the proportion of red interbedded with the gray, and it is not possible to select a definite boundary. It also appears probable that the Curtis grades laterally towards the east and south into red beds of Summerville lithology and that much of the decrease in the thickness of the Curtis in those directions is the result of this lateral change in lithology. A few miles east of the Green River the Curtis formation is absent, and the Summerville formation rests upon the Entrada sandstone.

No fossils were collected from the Curtis formation in the Green River Desert-Cataract Canyon region, but near the type locality in the San Rafael Swell this formation contains marine fossils of Upper Jurassic age. ${ }^{84}$ The correlation of the beds here named Curtis with the type locality of the formation in the Swell is unquestionable because of detailed tracing and mapping in the intervening area, similarity of lithology, and the stratigraphic position between the Entrada sandstone and Summerville formations.

Although no fossils were found east of the San Rafael Swell to indicate the marine origin of the Curtis formation, the similarity of the lithology of the formation in the eastern part of its area of outcrop with the lithology in the Swell, where it contains marine

\footnotetext{
83 Gilluly, James, and Reeside, J. B., Jr. (op. cit., pp. 106-107), measured the thickness of the Curtis formation at or near this locality as 51 feet. The discrepancy is probably due to the selection of different upper and lower boundaries.

${ }^{84}$ Gilluly, James, and Reeside, J. B., Jr., op. cit., pp. 78-79.
} 
fossils, leaves little doubt that marine waters extended eastward beyond the Green River and that the formation east of the Swell is a marine deposit. The greenish-gray beds of the Curtis extended only a short distance east of the Green River, and it seems probable that the lenticular, cross-bedded, medium- to coarse-grained sandstones, interbedded with finer-grained thin-bedded sandstone and shale of fairly uniform color and abundantly ripple-marked, represent deposition under shallow-water near-shore conditions. The presence of gypsum, which was probably deposited in a series of lagoons, is also suggestive of near-shore marine conditions.

\section{SUMMERVILLE FORMATION}

The Summerville formation overlies the Curtis and is the uppermost formation of the San Rafael group. It underlies the northern part of the area east of the San Rafael Swell but has been removed by erosion from practically all the area south of the San Rafael River. The main belt of outcrop of the Summerville, like the outcrop of the Curtis, is narrow and extends westward from the Green River in the northeastern part of T. 23 S., R. 16 E., to The Reef in the eastern part of T. 22 S., R. 13 E., thence northward along the east flank of The Reef to the north boundary of the area. North of the main belt of outcrop the formation is exposed on the north side of a fault in an isolated exposure on the bank of the Green River in secs. 33 and 34, T. 21 S., R. 16 E. Small remnants of the formation are present south of the main belt of outcrop in sec. 23, T. 24 S., R. 13 E., and in the Flattop Buttes near the Emery-Wayne County line. The Summerville normally crops out in steep slopes, which rise above the bench formed by the upper part of the Curtis formation and are capped by ledge-forming beds of the overlying Morrison formation; locally, parts of the formation form vertical walls. (See plś. 16 and 18,A.) The outcrops are usually practically barren of vegetation.

The Summerville formation consists principally of interbedded shale, mudstone, and subordinate platy sandstone in very thin regular beds. The beds, in general, are only a fraction of a foot thick. Weathered outcrops show only a vague banding and are a fairly uniform light chocolate brown, but fresh exposures are principally interbedded dark chocolate brown to maroon and greenish gray with some red, lavender, and gray. The formation contains occasional beds of medium- to fine-grained light-gray quartz sandstone usually 1 foot or less in thickness. Gypsum is locally abundant and occurs in beds with a maximum observed thickness of 17 feet, as nodular masses and as veins cutting across the bedding. Red chert in somewhat platy masses, like those found in the Curtis, may be found sparingly in the Summerville. Ripple marks are com- 
mon. The general aspect of the Summerville formation is strikingly similar to that of the Lower Triassic Moenkopi formation.

The following sections illustrate the lithology of the formation.

Section of the Summerville formation on west bank of the Green River in sec. 34, T. 21 S., R. $16 \mathrm{E}$.

Morrison formation.

Unconformity.

Summerville formation:

Shale, chocolate-brown, interbedded with gray, fine-grained ripplemarked sandstone, and nodular-weathering mudstone; bedding very thin and regular.

Sandstone, light-gray, fine-grained, ripple-marked, ledge-forming...

Shale, principally chocolate-brown, with some red and lavender in lower part, interbedded with fine-grained gray sandstone and chocolate-brown, nodular-weathering mudstone; contains some lenticular, thin limy concretions; bedding very thin and regular. Contact with the underlying Curtis is gradational

Curtis formation.

Section of the Summerville formation on the north side of the San Rafael River in sec. 11, T. 23 S., R. $14 \mathrm{E}$.

Morrison formation.

Unconformity.

Summerville formation:

Shale, brown, sandy, and thin beds of brown fine-grained platy sandstone; thin bed of greenish gypsum about 60 feet above base; nodular masses of white gypsum throughout entire series...

Shale, red-brown, sandy, with a few beds of thin-bedded, platy, ripple-marked sandstone; contains small nodules of gypsum near top

Measured thicknesses of the Summerville formation vary considerably but the variation may be due in large part to the lithologic gradation between Curtis and Summerville and the consequent difficulty of selecting a precise boundary between the formations at many localities. It is probable that the boundary as mapped is not everywhere at the same horizon. Measured thicknesses are 140 feet near the southwest corner of T. 20 S., R. 14 E., 205 feet near the Tidwell Ranch in sec. 32, T. 21 S., R. 14 E., 147 feet on the San Rafael River in sec. 11, T. 23 S., R. 14 E., 118 feet on the west bank of the Green River in sec. 34, T. 21 S., R. 16 E., 96 feet northwest of the mouth of the San Rafael River in sec. 20, T. 23 S., R. 16 E., 189 feet at the north end of Big Flattop Butte and 165 feet at the east end of the same butte. 
The base of the Summerville formation is conformable with the Curtis formation, and the contact is gradational. The upper contact of the Summerville is an unconformity with the basal beds of the overlying Morrison formation resting upon a surface of low relief. Locally, as in the southwestern part of T. 22 S., R. 14 E., there appears to be slight angular discordance at this contact. The discordance may be due to folding before the deposition of the Morrison formation but perhaps is best explained as due to deposition of the basal Morrison beds upon an eroded surface that locally beveled the upper few feet of the Summerville.

The type locality of the Summerville formation is in the San Rafael Swell, only about 5 miles northwest of the northernmost part of the area shown on plate $1 .^{85}$ The formation has been mapped in detail from its type locality eastward beyond the Green and Colorado Rivers. ${ }^{86}$ Toward the east the underlying Curtis formation appears to grade laterally into sediments of Summerville lithology, and east of the Green River, beyond the margin of the Curtis formation, the Summerville intertongues with the Entrada sandstone.

Although no fossils were found in the Summerville formation, the Upper Jurassic fossils in the underlying Curtis formation and in the overlying Morrison formation definitely show the age of the intervening Summerville formation to be Upper Jurassic.

The thin regular bedding of the Summerville formation seems to indicate deposition in water that was not greatly agitated by wave or current action, and the bedded gypsum offers fairly strong evidence that marine water had access periodically to the basin of deposition. Because of these conditions and the gradation, both horizontally and vertically, from the marine sediments of the Curtis formation, it is inferred that the Summerville formation represents accumulation of sediments near the margin of the Curtis sea, in part in shallow arms of the sea that were protected from the open ocean and in part in large shallow lagoons to which ocean water did not have rree access.

\section{MORRISON FORMATION}

The Morrison formation overlies the Summerville formation, the uppermost member of the San Rafael group, and is the youngest of the thick series of formations ranging in age from Permian to Jurassic that is commonly grouped under the term "Red Beds."

\footnotetext{
${ }^{85}$ Gilluly, James, and Reeside. J. B.. Jr., Sedimentary rocks of the San Rafael Swell and some adjacent areas in eastern Utah: U. S. Geol. Survey Prof. Paper 150, p. 80, 1928.

so McKnight, E. T., Geology of area between Green and Colorado Rivers, Grand and San Juan Counties, Utah: U. S. Geol. Survey Bull. 908, 1940 [1941]. Dane, C. H., Geology of the Salt Valley anticline and adjacent areas, Grand County, Utah: U. S. Geol. Survey Bull. 863, pp. 102-106, 1935 [1936]. Baker, A. A., Geology and oil possibilities of the Moab district, Grand and San Juan Counties, Utah: U. S. Geol. Survey Bull. 841, pp. 51-52, 1933.
} 
Its main belt of outcrop lies principally north of the San Rafael River and extends from the Green River westward to the San Rafael Reef, where the outcrop turns northward and extends to the boundary of the area. The formation has been stripped by erosion from the area south of the main belt of outcrop except on the Flattop Buttes, where the basal beds form the resistant caps. (See pl. 18, A.) The Morrison consists of beds resistant to erosion interbedded with softer beds and forms a succession of steps with steep slopes and low ledges bordering mesas or broad benches. The benches are more or less dissected and are cut by many small canyons:

The Morrison consists principally of interbedded sandstone, shale, and mudstone. The lower part of the formation contains more sandstone than the upper part and has been named the Salt Wash sandstone member. ${ }^{87}$ At most places in this area the basal bed of the Salt Wash member is massive white gypsum with a maximum observed thickness of about 20 feet, which forms a ledge at the top of steep slopes or cliffs formed by the underlying Summerville formation. At other places the basal bed of the formation is a light-gray unfossiliferous cherty limestone usually less than 5 feet thick. This limestone bed is the resistant rock forming the rim and much of the floor of broad benches of low relief in T. 23 S., Rs. 15 and 16 E., northwest of the mouth of the San Rafael River. In sec. 23, T. 23 S., R. 15 E., the limestone bed extends beneath the thick gypsum bed that is the basal bed of the Morrison farther west. Locally, neither gypsum nor limestone is present at the base of the Morrison. The Salt Wash sandstone is typically an alternating series of sandstone and shale or mudstone. The sandstone is usually ledge-forming and is in beds from less than 5 feet to more than 30 feet thick, but the beds are lenticular and vary greatly in thickness in short distances along the outcrop. The sandstone beds are fine- to cross-grained, with occasional streaks of grit or lenses of conglomerate containing siliceous pebbles with maximum diameter of half an inch or more. They are light greenish gray to brown and are usually cross-bedded. Silicified wood is common in the sandstone, and some of the sandstone beds contain vanadium-bearing minerals. The shale and mudstone interbedded with the sandstone is light to dark gray and reddish brown or red and is more or less variegated. Thin beds of unfossiliferous limestone or small nodular masses of limestone are present locally, and thin beds of sandstone are commonly present. The top of the Salt Wash member is placed at the top of the uppermost ledge that marks a conspicuous change in lithology from abundant sandstones in thick

\footnotetext{
${ }^{87}$ Lupton, C. T., Oil and gas near Green River, Grand County, Utah: U. S. Geol. Survey Bull. 641, p. 127, 1914.
} 
beds to dominantly shale with occasional beds of sandstone. The boundary is marked nearly everywhere by a broad bench from which the less resistant upper part of the formation has been stripped. However, the lenticular sandstones of the Salt Wash member are not continuous, and the upper boundary of the member is not marked everywhere by the top of the same sandstone bed. As measured along the Green River-Hanksville road in the eastern part of T. 22 S., R. 14 E., the Salt Wash member constitutes approximately the lower one-third of the formation and is 207 feet thick (see measured section, pp. 88-89) ; near the town of Green River in the southwestern part of T. 21 S., R. 16 E., its thickness is 185 feet.

Above the Salt Wash sandstone member the Morrison consists principally of mudstone and siltstone, with ledges of sandstone and conglomerate. The mudstone and siltstone are red, gray, lavender, and brown, in large part variegated in pastel shades of these colors. In places, thick sections of the mudstone are strikingly laminated in thin regular layers of different colors. (See pl. 18, B.) The mudstone contains occasional isolated pebbles up to 3 inches or more in diameter, which are smooth and show an exceedingly high polish. Interbedded with the mudstone and siltstone are beds of sandstone and conglomerate varying in thickness from a few inches to 35 feet or more. The sandstone is medium- to coarse-grained and, where conglomeratic, contains pebbles with a maximum observed diameter of about 3 inches, which consist principally of varicolored chert and quartzite. The sandstone is dominantly gray or buff; with several thin brown beds, and is irregularly bedded and cross-bedded. Near the top of the formation many of the sandstone and conglomerate beds have a siliceous cement and are quartzites. Thin discontinuous beds of nodular sandy limestone are present.

Measurements of thickness of the Morrison formation at two localities in the area were 637 feet along the road from Green River to Hanksville in the eastern part of T. 22 S., R. 14 E., and 590 feet along Green River in the southeastern part of T. $21 \mathrm{~S}$., R. 16 E. The following section measured along the Green RiverHanksville road shows the lithologic character of the formation.

Section of the Morrison formation measured along the road from Green River to Hanksville northeast of the bridge across the San Rafael River in sec. 27, T. 22 S., R. 14 E.

Mancos shale.

Unconformity.

Morrison formation:

Feet

Shale, gray, with some interbedded siliceous limestone.

$20 \pm$

Conglomerate, gray, siliceous ledge-forming ; pebbles consist mostly of gray chert and quartzite; measurement made on small mesa 
east of road, but where road crosses ledge it consists of a lower bed of conglomerate 6 feet thick and an upper conglomerate bed 11 feet thick, separated by 17 feet of variegated shale containing limestone nodules.

Shale, variegated, with abundant nodules of siliceous gray limestone and a few thin beds of dark-brown limy sandstone

Conglomerate with little matrix but includes occasional lenses of coarse-grained sandstone; pebbles are varicolored, consist principally of quartzite and chert, and have a maximum diameter of about 3 inches; ledge-forming:

Shale, variegated in pastel shades of red, gray, lavender, and brown, evenly banded, includes many thin lenticular beds of nodular sandy limestone.

Sandstone, light-gray, medium-grained; weathers into steep smooth shalelike slopes.

Shale, lavender below and grading upward through gray to red, includes a few thin beds of soft medium-grained sandstone.

Sandstone, yellowish-gray, coarse-grained, cross-bedded, conglomeratic with pebbles 1 inch in maximum diameter consisting of varicolored chert and quartzite.

Shale, variegated in pastel shades of red, gray, and lavender, includes a few thin beds of dark-brown coarse-grained sandstone......

Sandstone, gray, massive, cross-bedded, conglomeratic; the top of this bed is the top of the Salt Wash member

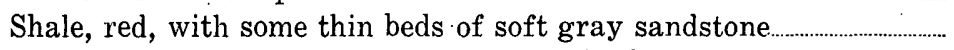

Sandstone gray, coarse-grained, cross-bedded.

Shale, sandy, greenish-gray.

Sandstone, gray, coarse-grained, massive, conglomeratic with pebbles half an inch in diameter consisting of gray, black, brown, and red chert.

Shale, light- to dark-gray with some reddish-brown.

Sandstone, gray, coarse-grained, cross-bedded, with streaks of chert pebbles, ledge-forming...

Mudstone, variegated.

Sandstone, light-brown, irrregularly bedded......................................................

Mudstone, variegated

Sandstone, light-gray, fine-grained, cross-bedded, with streaks of chert grit, ledge-forming.

Sandstone, gray, gritty, interbedded with nodular-weathering purplish-gray sandy limestone containing fresh-water fossils.

Gypsum, white, massive, with small brilliant red, somewhat platy aggregates of chert and small lenses of gypsiferous gray sandstone

Unconformity.

$637 \frac{1}{2}$

Summerville formation.

As described on page 86, the Morrison formation rests unconformably upon the Summerville formation. It also is marked at the top by a slight unconformity with the overlying Dakota (?) sandstone or Mancos shale resting upon an eroded surface of low relief. 
The Morrison formation is present in a large area in eastern Utah and adjacent States. Its regional stratigraphic relations have been described, and the evidence for its Jurassic age have been presented in another report. ${ }^{88}$ Except for silicified wood, the only fossils found in the Morrison formation in the Green River DesertCataract Canyon region were collected from gray sandstone and purplish-gray sandy limestone immediately overlying the basal gypsum bed, on the point of the bluff southeast of the bridge across the San Rafael River on the Hanksville road. The fossils were identified by J. B. Reeside, Jr., as Unio stewardi White.

The Morrison formation seems clearly to have been deposited under fluviatile and lacustrine conditions. The sandstones are lenticular, cross-bedded, and in part conglomeratic and probably were deposited by shifting streams, whereas the mudstone and siltstone represent flood-plain and lacustrine deposits. The unfossiliferous limestone bed at the base of the formation in parts of the area probably is also of fresh-water origin, but the thick gypsum bed that elsewhere forms the base of the formation is not readily explained as a deposit of fresh-water origin. A local source of gypsum existed in the Summerville formation, which possibly supplied material in solution that was redeposited in a shallow Morrison lake.

\section{CRETACEOUS SYSTEM \\ UPPER CRETACEOUS SERIES \\ DAKOTA(?) SANDSTONE}

The Dakota (?) sandstone overlies the Morrison formation and crops out only in the northern part of the area. The sandstone is thin and lenticular and is not always present between the Morrison formation and Mancos shale. It crops out intermittently along a line parallel to and 1 to $11 / 2$ miles west of the railroad in the extreme northern tip of the area and in an arc that trends south and west from the town of Green River.

The formation consists of irregularly bedded, cross-bedded bright yellowish-brown conglomerate and sandstone and, locally, interbedded gray shale and black carbonaceous shale. The pebbles in the conglomerate, which are rounded and to some extent polished, are composed principally of gray quartzite and black and red chert an inch or more in maximum diametex; many of them show small abrasions where they have been in contact with other pebbles. Silicified wood is abundant at many places. The maximum observed thickness of the formation is 40 feet, but at nearly all outcrops its thickness is 25 feet or less. The Dakota (?) rests in depressions on

\footnotetext{
${ }^{88}$ Baker, A. A., Dane, C. H., and Reeside, J. B., Jr., Correlation of the Jurassic formations of parts of Utah, Arizona, New Mexico, and Colorado: U. S. Geol. Survey Prof. Paper 183, pp. $9-10,47-48,58-63,1936$.
} 
the Morrison surface, and individual bodies of the sandstone have a lenticular cross section. In the center of the thicker lenses the conglomerate sandstone is thick-bedded, but near the margins it grades into yellow sandstone and sandy clay. Although the Dakota (?) standstone is similar in composition to the conglomeratic sandstone of the underlying Morrison formation, its bright orangebrown color serves to distinguish it from the underlying somber gray rocks.

The unconformity at the base of the Dakota (?) sandstone has local relief of 25 to 40 feet, equivalent to the thickness of the lenses of sandstone that were deposited in depressions on the Morrison surface. The overlying Mancos shale rests conformably upon the Dakota (?) sandstone, and the basal beds of the Mancos at many places consist of reworked Dakota (?) sand, which contains the fossil shells of Gryphaea newberryi Stanton. At most places in the area the Dakota (?) is absent and the Mancos rests directly upon the Morrison formation.

Fossil plants collected by Richardson ${ }^{99}$ near Elgin, across the river from the town of Green River and near Woodside, about 7 miles northwest of this area, were identified by F. H. Knowlton as of Dakota age. The Dakota (?) sandstone also corresponds in stratigraphic position and general lithology with the Dakota sand'stone, but because of the distance from the type locality and the uncertainty of its precise equivalence the name is here used with a query.

The discontinuous bodies of Dakota (?) sandstone may be channel filling and fluviatile deposits, which filled irregularities on the Morrison surface and formed an aggraded plain over which the Cretaceous Mancos sea advanced, or possibly they represent in large part the initial or littoral deposits of the advancing Mancos sea.

\section{MANCOS SHALE}

The Mancos shale conformably overlies the Dakota (?) sandstone and crops out only in the extreme northern part of the area. Its outcrop forms a broad barren area of low relief, which extends to the Book Cliffs beyond the north boundary of the map..$^{90}$

The Mancos shale is a nearly homogeneous drab bluish-gray shale. Veinlets of calcite are common and selenite crystals are abundant on weathered slopes. Interbedded with the shale are a few thin beds of gray to brown sandstone and yellowish sandy shale, which commonly form low ridges and dip slopes. Near the

\footnotetext{
${ }^{80}$ Richardson, G. B., Reconnaissance of the Book Cliffs coal field between Grand River, Colo., and Sunnyside, Utah: U. S. Geol. Survey Bull. 371, p. 14, 1909.

${ }^{00}$ Fisher, D. J., The Book Cliffs coal field in Emery and Grand Counties, Utah: U. S. Geol. Survey Bull. 852, pp. 5-6, 1936. 
town of Green River, the most prominent sandy zones are 120, 160, 195, and 325 feet above the Dakota (?) sandstone and in sec. 33 , T. 19 S., R. 14 E., conspicuous thin sandstone beds are 120, 144, and 287 feet above the Dakota (?). The interval from the Dakota (?) to the uppermost bed is 335 feet in sec. 12, T. 22 S., R. 14 E. This upper sandstone bed, 287 to 335 feet above the Dakota (?) is tentatively correlated with the Ferron sandstone member of the Mancos of Castle Valley west of the San Rafael Swell,91 which, however, is about 600 feet above the base of the formation. The Ferron sandstone near Green River is a sandy shale, but it is sufficiently resistant to erosion, compared to the enclosing shale, to form a rather prominent ridge. The outcrop of the Ferron sandstone member is not shown on the map. (See pl. 1.) The sandstone caps the ridge adjacent to and west of the Green River-Hanksville road for 4 miles south of Green River, where it is offset by faulting; the outcrop trends west, from a point on Green River in sec. 5, T. 22 S., R. 16 E., then north, a mile or less from the outcrop of the Dakota (?) sandstone, and crosses the Green River-Hanksville road in sec. 8, T. 22 S., R. $15 \mathrm{E}$.

The total thickness of the Mancos shale exposed in the area was not determined, but it is estimated that it is approximately the basal 800 feet of the formation that is exposed southwest of the large fault passing diagonally through T. 21 S., R. 15 E.

Marine fossils of Cretaceous age are abundant in the Mancos.

\section{TERTIARY (?) AND QUATERNARY SYSTEMS}

\section{TERRACE DEPOSITS AND ALLUVIUM}

Thin deposits of cemented gravel and caliche, which are not shown on the map (pl. 1), form a ledge at the rim of the nearly flat summits of most of the higher buttes, mesas, and ridges east of the San Rafael Swell between the San Rafael River and that part of the divide between the Dirty Devil and Green River drainage extending from Twin Corral Flats to the San Rafael Reef.

The gravel and caliche deposits are 3 to 10 feet or more thick and consist of angular to rounded boulders of sandstone, limestone, and quartzite embedded in caliche. The boulders vary in size but are usually less than a foot in diameter; at one locality near the Reef at Straight Wash the gravel contains boulders up to 3 feet in diameter. At some places the gravel is more or less uniformly distributed through the caliche; at other places the deposit is caliche with few boulders; elsewhere the lower few feet of the deposit are dominantly a conglomeratic cross-bedded gray sandstone, which grades up into caliche with few pebbles or boulders.

${ }^{91}$ Spieker, E. M., The Wasatch Plateau coal field, Utah: U. S. Geol. Survey Bull. 819, pp. 18-20, 1931. 
The deposits are present at altitudes that, in general, rise toward the west and south. A few miles southwest of the mouth of the San Rafael River they are at an altitude of about 4,800 feet. Immediately south of Iron Wash, on the ridge that is crossed by the road from Green River to Hanksville, they rise westward from an altitude of 4,565 to 4,790 feet in a distance of about 6 miles. Near the Reef on the ridge between Swazy's seep and Garvin's Ranch the altitude of the caliche bed is 5,265 feet, and to the east it slopes downward 380 feet in 7 miles. On the ridge north of Twin Corral Flats its altitude is 6,330 feet and the altitudes at various points north to the mouth of the San Rafael River show a quite regular downward slope of about 1,800 feet in 31 miles. The altitudes of the caliche-floored surface on the Spur, however, show the caliche to be at a higher level than in the country to the west in the vicinity of Antelope Valley. Near John's Spring the altitude is 5,660 feet and it rises toward the south to an altitude of 6,015 feet, a difference of 355 feet in a distance of about 5 miles. The differences in altitude between outcrops on the Spur and outcrops west of Horseshoe Canyon show a downward slope to the west of about 40 feet to the mile for a distance of about 6 miles. .

The caliche does not occur as a surficial deposit on a single widespread surface but rests upon a terraced surface. The risers between terraces are abrupt, and the intervals between terraces range from a few feet to 55 feet or more. As these terraces were not mapped in detail, information is not available regarding the extent of each terrace. The trend of the risers between terraces varies throughout the area. In the western part they trend at right angles to the Reef, more or less parallel to the present drainage, and the steplike profile produced by the series of terraces rises toward the south. (See pl. 16.) In the vicinity of Robbers Roost Flats the cross-section profile of a series of small caliche-covered terraces rises toward the east and west from approximately a medial north-south line through the Flats.

The caliche was deposited upon pediment surfaces which sloped eastward from the foot of the Reef and upon surfaces that appear to have been developed as pediments adjoining high cliffs near the divide between Dirty Devil and San Rafael Rivers. The Flattop Buttes are probably small, low remnants of these cliffs. Such pediments with their characteristic terraced cross sections are well developed adjacent to the Henry Mountains, ${ }^{92}$ and also along the front of the Book Cliffs where Rich ${ }^{93}$ has described the erosion

\footnotetext{
${ }^{82}$ Hunt, C. B., Geology and geography of the Henry Moúntains structural basin, Utah: U. S. Geol. Survey report (in preparation).

m Rich, J. L., Origin and evolution of rock fans and pedinents, Geol. Soc. Amer., Bull., vol. 46. pp. 999-1024, 1935.
} 
process controlling their development. Practically all the pediment surfaces in the Green River Desert have been cut across outcrops of the Entrada sandstone, and the caliche deposited upon the surfaces may have been formed by the precipitation of calcium carbonate derived by leaching the lime cement in the sandstone.

The age of the gravel and caliche deposits is not the same in all parts of the area. The deposits at the highest levels, especially those that cap high intercanyon divides in the eastern part of the area, must have been deposited at a time when the streams were not confined in deep canyons as at present and were relatively free to shift their position and form the pediment surfaces upon which the deposits rest. The writer believes that these high-level deposits are not younger than the early stage of excavation of the present Green River canyon. Younger deposits were formed on lower pediment. surfaces as erosion of the region continued. The conditions favorable for the deposition of the caliche and the gravel have evidently continued to relatively recent times for the lower level deposits near the Reef are not far above the present drainage channels.

Terrace gravels are present at many places along the San Rafael and Green Rivers and are especially prominent near the mouth of the San Rafael River where they are present at several levels up to about 350 feet above the present position of the rivers at their 'junction.

Deposits of gravel and alluvium are commonly present along the major streams, but, in general, only the larger areas are shown on the map. The only evidence known to the writer with respect to the depth of the alluvium along the Green or the Colorado River was supplied by four holes drilled in the bed of the Colorado River just below its junction with the Green River. The wells, which were drilled in connection with the study of a proposed dam site by the United States Reclamation Service, failed to reach bedrock at depths of 90 to $1241 / 2$ feet. $^{94}$

\section{STRUCTURE}

The rocks of southeastern Utah are folded into large anticlinal upwarps and synclinal basins, which are modified by many subordinate folds and are cut by many normal faults. (See pl. 20.) ${ }^{9 \check{J}}$ The southern part of the Green River Desert-Cataract Canyon region includes the gently dipping northwestern part of the plunging north end of one of these large anticlines - the Monument upwarp-which trends nearly due south and extends to the Arizona-

\footnotetext{
04 U. S. Reclamation Service 15th Ann. Rept., pp. 515-516, 1916.

${ }^{25}$ Baker, A. A., Geologic structure of southeastern Utah: Am. Assoc. Petroleum Geologists Bull., vol. 19, pp. 1472-1507, 1935.
} 
Utah State line. The San Rafael Swell, which is about 100 miles long, is another of the large upwarps; it trends about N. $30^{\circ} \mathrm{E}$. and part of its steeply dipping east flank crosses the northwestern part of the area. A large synclinal basin, the axis of which is west of the Henry Mountains, lies between the Monument upwarp and the San Rafael Swell but is principally southwest of the Dirty Devil River. East of the San Rafael Swell in the northern part of the area the rocks have, in general, low dips toward the north into the Uinta Basin. A low, poorly defined, structural ridge separates the northward-dipping rocks on the limb of the Uinta Basin from the basinward-dipping rocks on the limb of the Henry Mountains syncline and extends southeastward from the San Rafael Swell in the vicinity of the Emery-Wayne County line.

The rocks are broken by normal faults at many places. Most of the faults are steeply dipping, have small displacements, and trend N. 45 to $65^{\circ} \mathrm{W}$.

In the northern part of Cataract Canyon the rocks in the canyon walls and on the plateau surface immediately adjoining the canyon are tilted and broken by many normal faults, apparently as the result of flowage in the underlying plastic salt and gypsum beds of the Paradox formation.

\section{METHODS OF REPRESENTING STRUCTURE}

The geologic structure of the area is shown on plate 2 , which gives the location of faults, the attitude of the rocks in all parts of the area by contours, and a cross section extending from the axis of the San Rafael Swell to Cataract Canyon. The contour lines are drawn on the base of the Wingate sandstone in most of the area, but the base of the Shinarump conglomerate was used as the datum plane in the San Rafael Swell; an irregular line along the east side of the Swell marks the change in the datum planes. The contour lines connect points of equal altitude above sea level on the selected datum planes. They are drawn from numerous altitudes determined in the field on the datum planes selected for contouring and from altitudes on other strata where the stratigraphic intervals to the selected datum planes are known.

The faults are shown in the position and with the displacement that they have at the surface. No attempt has been made to indicate the position that the faults would have if their planes were projected to the datum planes used for contouring, and consequently no interpretation as to possible change of inclination of the fault plane or possible change in displacements along the faults with depth has been introduced in drawing the contours.

The structure cross section on plate 1 is drawn with the same horizontal and vertical scale, and there is therefore no distortion 
of structural features due to differences in scale. Because of the small scale of the cross section it is not possible to show minor irregularities of the attitude of the rocks. In addition to depicting the structure the cross section also shows the major surface features along the line of the section and the effect of different formations in controlling the steepness of surface slopes.

\section{DETAILS OF THE FOLDS}

SAN RAFAEL SWELI.

The San Rafael Swell, only part of the east flank of which is shown on plate 2 , is a huge anticlinal fold about 100 miles long and 50 miles wide, as shown on the structure map of southeastern Utah. (See pl. 20.) Gilluly ${ }^{96}$ has described the geology of the greater part of the Swell, and Hunt ${ }^{97}$ has mapped the southern part of its eastern flank. It is an asymmetric anticline with its axis slightly convex toward the east but trending about N. $30^{\circ} \mathrm{E}$. The western flank has an average dip of $4^{\circ}$ or $5^{\circ}$, but the eastern flank dips more steeply with the amount of dip increasing from $10^{\circ}$ or less near each end to a maximum of about $85^{\circ}$ a few miles north of Straight Wash. At the foot of the Reef the eastern flank flattens abruptly, and the rocks have a relatively low dip in the Green River Desert. The structural relief on the eastern flank is about 4,000 feet. The crest of the fold is broad and gently rounded with a sinuous axis and as shown by Gilluly has several subordinate low longitudinal folds; opposite the most steeply dipping part of the eastern flank the flattened crest of the fold extends much farther east.

The crest and eastern flank of the Swell are cut by several small normal faults, which trend nearly at right angles or are oblique to the strike of the rocks. None of the faults extends entirely across the eastern limb of the anticline from the axis of the fold to the area of gently dipping rocks in the Green River Desert, and no faults were observed with a trend parallel to the strike of the rocks.

The oldest rocks exposed in the San Rafael Swell crop out in the canyon of Straight Wash; they consist of interbedded sandstone, and limestone, which underlie the Coconino sandstone and are tentatively correlated with the Hermosa formation. The uppermost beds of this series of rocks are probably exposed in the Black Box of San Rafael River where Gilluly ${ }^{98}$ reports limestone at the base of the Coconino sandstone.

The Coconino sandstone and the overlying thin Kaibab lime-

${ }^{96}$ Gilluly, James, Geology and oil and gas prospects of part of the San Rafael Swell, Utah: U. S. Geol. Survey Bull. 806, pp. 69-130, 1929.

${ }^{97}$ Hunt, C. B., Geology and geography of the Henry Mountains structural basin: U. S. Geol.

Survey report (in preparation).

${ }^{98}$ Gilluly, James, op. cit., p. 81 . 
stone form a floor for large areas on the eastern flank of the Swell, but the Moenkopi formation is the surface rock of a large part of the fold, where it forms a thin veneer over the more resistant older rocks. The younger rocks from the Moenkopi to the Entrada crop out in the relatively narrow band of steeply dipping beds along the Reef.

\section{MONUMEN'T UPWARP}

The Monument upwarp is a large asymmetric anticlinal fold similar to the San Rafael Swell. As shown on plate 20, it extends from north of the junction of the Green and Colorado Rivers nearly due south into northern Arizona and is approximately 125 miles long with a maximum width of about 75 miles. The northwestern part of the plunging north end of the anticline extends northwestward from Cataract Canyon approximately to the Emery-Wayne County line. Near the mouth of the Dirty Devil River the dip of the rocks is nearly due west, but toward the Green River the dip gradually shifts to a more northerly trend, and near the mouth of the Green River it is about N. $35^{\circ} \mathrm{W}$. The dip is slight and in general is very regular. Northwestward from the mouth of the Green River the average northwesterly dip for a distance of about 20 miles is only about 115 feet per mile; near the mouth of the Dirty Devil River, the westward dip of the rocks is about 250 feet per mile, but a few miles toward the east in the vicinity of the mouth of Dark Canyon it is somewhat less. The southwestward trending Cataract Canyon cuts diagonally across the curving limb of the Monument upwarp, and the canyon reaches its greatest depth near the mouth of Gypsum Canyon where the river crosses the highest part of the fold along its course.

A few small normal faults are present on the monoclinal slope. They are most abundant along Cataract Canyon where; however, they are local phenomena related to movements in the underlying Paradox formation. (See pp. 101-103.) Elsewhere the faults in general trend northwest nearly at right angles to the strike of the rocks.

AN'TCLINES IN THE VICINITY OF THE EMERY - WA YNE COUNTY LINE

As is well shown on the regional structural map of southeastern Utah (pl. 20), there is a structural ridge extending southeastward from the eastern flank of the San Rafael Swell about midway between the San Rafael and Dirty Devil Rivers. Its southwestern flank slopes into the Henry Mountains structural basin, its northeastern flank into the Uinta Basin. Prommel ${ }^{99}$ applied the name "Nequoia Arch" to this structural ridge, although he extended it

${ }^{99}$ Prommei, H. C., Anticlines on Nequoia Arch, Green River Desert, Utah: Oil Weekly, vol. 47, pp. 310, 318, 1927 . 
to Cataract Canyon, thus including part of the plunging north end of the Monument upwarp. The arch is a distinctive structural feature only from the San Rafael Swell to approximately the EmeryWayne County line (pl. 2) beyond which it cannot be distinguished, although a continuation of the structural disturbance is expressed in a group of small domes and synclinal basins, which modify the regional dip and extend as far east as the Spur.

The low anticlines and shallow synclines associated with this structural arch are difficult to map satisfactorily. Much of the area is covered by wind-blown sand or high-level caliche deposits. Where bedrock is exposed, it is the Entrada sandstone, which is irregularly bedded, and individual beds of this sandstone are of doubtful value for use in determining the smaller details of structure even if they can be correlated between outcrops. Similarly, where the underlying Carmel formation is exposed, its contact with the Entrada sandstone is so irregular that it is useful only in determining the broader structural features. The contouring of this group of low folds, as shown on plate 2, should therefore be considered only as an approximate indication of their configuration.

Flattop Buttes anticline and subsidiary Big Flattop Butte and Sweetwater domes. - The Flattop Buttes anticline extends from Temple. Mountain Wash in the northeastern part of T. 25 S., R. $12 \mathrm{E}$., southeastward about 17 miles to northern Wayne County about $31 / 2$ miles south of Sweetwater spring. A saddle near Temple Mountain Wash separates the anticline from the San Rafael Swell and is about 4,000 feet structurally below the crest of the Swell. From the saddle the crest of the anticline rises about 350 feet in 12 miles to the apex of the Big Flattop Butte dome, near the southeast end of the Big Flattop Butte. The Big Flattop Butte dome is a broad low dome, which has a closure of about 100 feet toward the southeast where a shallow saddle crosses the axis of the anticline. From this saddle the crest of the anticline rises toward the southeast about 150 feet to the apex of the Sweetwater dome, the highest part of the Flattop Buttes anticline. The distance from the apex of the Big Flattop Butte dome to the apex of the Sweetwater dome is about $21 / 2$ miles. Toward the southeast the Sweetwater dome is separated from the long monoclinal slope forming the flank of the Monument upwarp by a saddle that is 2 miles distant from and structurally about 200 feet below the apex of the dome. Two low anticlines separated by a shallow syncline project from the Sweetwater dome northeastward between Sweetwater spring and Jack's Knob. The eastern anticline has a low dome west of Jack's Knob with a closure of about 50 feet at a shallow saddle that separates it from the Sweetwater dome. Elsewhere the north- 
eastern flank of the Flattop Buttes anticline dips less than $1^{\circ}$ for a distance of 10 miles or more toward the Uinta Basin. The southwestern flank also dips $1^{\circ}$ or less to the boundary of the area mapped and forms part of the flank of the Henry. Mountains structural basin.

The surface rocks over most of the upper part of the anticline are the Carmel formation and the Entrada sandstone. The Curtis formation crops out at the crest of the Sweetwater dome. The Curtis, Summerville, and basal Morrison formations crop out in the Flattop Buttes.

Barrier Creek anticline.-The Barrier Creek anticline is situated principally in Wayne County and extends from the Spur northwestward across Horseshoe Canyon into Antelope Valley. The name Barrier Creek canyon has been applied by some people to Horseshoe Canyon, which is a deep narrow canyon that prevents access to the Spur from the north and west.

The anticline plunges northwestward and has a closure of about 150 feet to the southeast between the highest part of the fold and a structural saddle that intervenes between it and the long northwestward-dipping monoclinal slope of the flank of the Monument upwarp. The highest part of the anticline is slightly more than a mile northwest of the saddle and is about $11 / 2$ miles southeast of Horseshoe Canyon. At its highest part the anticline is about 4 miles wide between the axes of shallow northwestward-plunging synclines that limit it on both sides; the maximum dip on the flanks of this part of the anticline is about $3^{\circ}$. Northwest from the apex the anticline extends about 5 miles to Antelope Valley in southerm Emery County where it merges with the regional northerly dip into the Unita Basin. The crest of the anticline plunges northwestward about 500 feet in this distance. The anticline also narrows toward the northwest and the flanks dip more steeply with maximum dips of about $71 / 2^{\circ}$.

The oldest rocks exposed at the crest of the anticline are the uppermost beds of the Kayenta formation, which crop out in the bottom of Horseshoe Canyon. The walls of the canyon and the surface rocks, on much of the anticline southeast of Horseshoe Canyon and to a lesser extent northwest of the canyon, are the Navajo sandstone.

Bluejohn anticline.-The Bluejohn anticline is about 5 miles southwest of the Barrier Creek anticline. It is similar to the Barrier Creek anticline but is a less prominent structural feature. The axis of the anticline trends about N. $40^{\circ} \mathrm{W}$. Bluejohn Canyon crosses the highest part of the anticline, which is about 50 feet higher than a structural saddle to the southeast that intervenes between the anticline and the northwestward-dipping flank of the 
Monument upwarp; the saddle is three-quarters of a mile southeast of Bluejohn Canyon. Toward the northwest from its apex the plunging nose of the anticline extends for about 5 miles nearly to North Spring, and the axis of the anticline decreases in altitude about 400 feet in that distance. The flanks of the anticline have a maximum dip of about $31 / 2^{\circ}$. The southwestern flank terminates at the axis of a shallow northwestward-plunging syncline whose axis is 1 to $11 / 2$ miles southwest of the axis of the anticline, and the northeastern flank terminates at the axis of the shallow northwestward-plunging syncline that separates the Bluejohn and Barrier Creek anticlines and is about 3 miles northeast of the axis of the Bluejohn anticline.

The oldest rocks exposed at the crest of the anticline are the uppermost beds of the Kayenta formation, which crop out in the lower walls of Bluejohn Canyon. The Navajo sandstone is the surface rock over most of the anticline, but the overlying Carmel formation and Entrada sandstone are present on its northwestern part.

Whitbeck Knoll anticlinal nose.-The anticlinal nose plunging northward from Robbers Roost Flat through Whitbeck Knoll to the Emery-Wayne County line is largely inferred from the trend of the rocks in the surrounding area. Wind-blown sand or caliche deposits cover most of the area, and there are only small isolated outcrops of Entrada sandstone. It is possible that a closed dome, similar to the Barrier Creek and Bluejohn domes, is present on this anticlinal nose.

ATITIUDE OF THE ROCKS IN THE NORTHERN PART OF THE GREEN RIVER DESERT

North of the group of anticlines in the vicinity of the EmeryWayne County line and east of the San Rafael Swell the rocks have a low dip, which in general is toward the north. As shown on the regional structure map ( $\mathrm{pl} .20)$, the rocks are slightly folded to form a broad, very shallow northward-plunging syncline, which is between the San Rafael Swell on the west and an anticlinal nose east of the Green River that is a northwesterly continuation of the Cane Creek anticline. Except for occasional faults and associated local tilting of the rocks, the syncline plunges northward uninterruptedly and forms part of the southern flank of the Uinta Basin.

The Carmel formation and the Entrada sandstone are the principal surface rocks in the southern half of the area occupied by the syncline. With the exception of relatively minor repetition of the beds by faulting, progressively younger rocks are exposed toward the north and the Mancos shale is the surface rock at the north boundary of the area. 
FOLDS AND FAULTS RELATED TO FLOWAGE IN THE

PARADOX FORMATION

Along the walls of the upper part of Cataract Canyon and on the plateau surface immediately adjacent to the west canyon rim, the rocks are irregularly tilted and are broken by many faults, in marked contrast with the regularly dipping and scarcely faulted rocks of most of the area. Because of the small scale of the map (pl. 1) it is not practicable to attempt to show more than a few of the innumerable small faults in the disturbed zone. (See pl. 19, A.) The width of the zone of structural disturbance ranges up to 1 to $11 / 2$ miles from the river, the differences being due in part to the meandering course of the river. In general, the rocks dip northwestward away from the river, but in detail they dip in almost every direction; the amount of dip ranges up to a maximum of $30^{\circ}$ or more, the maximum dips being in the canyon wall. Normal faults, most of which have a displacement of less than 100 feet, are roughly parallel to the course of the river. A few of the faults diverge considerably from parallelism with the river but others show close agreement. Most of the faults limit downthrown or graben blocks, but a few of them limit blocks downthrown toward the canyon and in a few places a series of faults bound blocks, each of which is downthrown toward the canyon in a steplike arrangement. The blocks downthrown toward the canyon are commonly sharply tilted away from the canyon and are suggestive of the tilting in landslides. The width of the graben blocks varies from about 100 feet to 1,000 feet; the largest graben forms the topographic depression, Surprise Valley, extending across the promontory between Spanish Bottom and the next tributary canyon to the south. (See pl. 19, B.) A fault extending eastward from Surprise Valley. approximately bisects the promontory the northern half of which is a conspicuous example of a block downfaulted toward the river and tilted away from it.

East of the river similar tilting and faulting is found but in general the dip is toward the east, 1 thus forming a narrow intensely faulted anticlinal arch that follows the course of the canyon. The arch continues northeastward along the canyon of the Colorado River for several miles above the mouth of the Green River. ${ }^{2}$

The arching and faulting along the canyon probably is the result of flowage in the Paradox formation. Gypsum of the Paradox

\footnotetext{
1 Baker, A. A., Geology and oil possibilities of the Moab district, Grand and San Juan Counties, Utah: U. S. Geol. Survey Bull. 841, pp. 71-76, 1933.

2 McKnight, E. T., Geology of area between Green and Colorado Rivers, Utah: U. S. Geol. Survey Bull. 908, 1940 [1941].
} 
formation crops out at two places in upper Cataract Canyon (pl. 1), where it forms nearly circular plugs; the diameters of the plugs range from about 1,500 to 2,500 feet and their tops are 200 to 300 feet above river level. At each locality the overlying Hermosa formation dips as much as $30^{\circ}$ to $40^{\circ}$ in all directions away from the center of the plug. However, the full thickness of the Hermosa formation is not present above the gypsum outcrops of the Paradox in Cataract Canyon; the gypsum probably has been intruded into the overlying rocks and is above its normal stratigraphic position. As the plugs of plastic rock moved upward, the force exerted arched the overlying rocks around them. Similar forces caused the arching of the rocks in other parts of the canyon of the Colorado River, but if plugs of plastic material have been forced into the overlying Hermosa at other places along the canyon, erosion has not yet exposed them at the surface, except at one locality noted by Page. (See p. 23.)

The writer agrees with Harrison ${ }^{3}$ that the arching and the associated faulting occurred in relatively recent time, after the topography of the region had acquired essentially its present form. The weight of the overlying rocks upon the plastic rocks of the Paradox formation in areas adjoining the canyon apparently was sufficient to cause flowage, causing the plastic rocks to thrust upward and arch the thin cover of overlying rocks along the canyon. The plugs of plastic material observed by the writer in Cataract Canyon had pierced the cover at the mouths of tributary canyons where the strength of the cover probably was weakest because of the incision of the tributary canyons adjacent to the river canyon. Flowage of the plastic material into the arch and through the vents to the surface would cause a settling of the overlying rocks in areas adjoining the canyon. The graben and step faulting on both sides of the river are believed to have taken place during this settling. The wider belt of graben faulting on the east side of the river is in a shallow syncline (pl. 20), which seems to be indicative of the movement of a considerable volume of the plastic material and the sinking of the overlying rocks. That the graben faulting is of recent date east of the river near the mouth of the Green River is shown by the relationship of old drainage lines to the grabens. Old drainage channels can be traced across the faulted area, but they are interrupted by transverse down faulted blocks forming graben valleys, in some of which drainage channels have not yet been developed. ${ }^{4}$

\footnotetext{
${ }^{3}$ Harrison, T. S., Colorado-Utah salt domes: Am. Assoc. Petroleum Geologists Bull., vol. 11, pp. 125-127, 1927.
}

4 Baker, A. A., op. cit., p. 74. 
Prommel and $\mathrm{Crum}^{5}$ also have described the folding of the rocks and the occurrence of gypsum plugs in Cataract Canyon. They concluded that the plugs were intruded into the overlying formations contemporaneously with late Pennsylvanian and Permian folding and that the arching of the beds along the river is of similar origin and is independent of the present topography.

\section{FAULTS}

The faults along Cataract Canyon have been briefly described in connection with the arching of the beds along the canyon, and the following descriptions apply only to faults in other parts of the Green River Desert-Cataract Canyon region.

Normal faults are present at many places in the area. The strike of the faults ranges from about N. $15^{\circ} \mathrm{W}$. to about S. $85^{\circ} \mathrm{W}$. but has a dominant trend of about $\mathrm{N} .40^{\circ}$ to $55^{\circ} \mathrm{W}$. The trend of the faults has no consistent relationship to the attitude of the rocks, as the northwestward trending faults displace rocks dipping in several directions. The displacements range from a few feet to more than 700 feet, but few of the faults have displacements exceeding 150 feet. Many adjacent faults have opposite displacements and limit downthrown or graben blocks; there is no uniform or markedly dominant direction of displacement. Most of the fault planes that could be measured dip steeply in the direction of the downthrown block or are practically vertical. A few fault planes have dips of less than $70^{\circ}$ and none were observed with dips of less than $60^{\circ}$. Most of the faults could be followed for distances of 4 miles or less but it is possible that some of them are much longer, because faults of small displacement may not be recognized where they do not cross contacts of different formations at the outcrop.

The largest fault trends about N. $55^{\circ} \mathrm{W}$. across the northern part of the area about 3 miles southwest of the town of Green River. Near the Green River, it has a maximum displacement of 700 to 750 feet where uppermost Morrison is faulted against uppermost Entrada. Northwestward the fault showed gradually decreasing displacement, as traced for 16 miles to its termination on the flank of the San Rafael Swell in the southwestern part of T. 20 S., R. 14 E. Toward the southeast this fault is part of a nearly continuous fault zone, which has a sinuous trend and extends through Salt Valley practically to the Utah-Colorado State line (pl. 20); the total length of the fault zone is about 80 miles. The second-largest fault in the area trends about N. $50^{\circ} \mathrm{W}$.

\footnotetext{
5 Prommel, H. W. C., and Crum, H. E., Salt domes of Permian and Pennsylvania age in southeastern Utah and their influence on oil accumulation: Am. Assoc. Petroleum Geologists Bull., vol. 11, pp. 381-382, 1927.
} 
and has been traced about 16 miles southeastward from the flank of the San Rafael Swell in the northwestern part of T. 24.S., R. $13 \mathrm{E}$.; the maximum displacement on this fault is 450 to 500 feet in the southeastern part of T. 24 S., R. 13 E., where basal Entrada sandstone is faulted against the Curtis formation. A fault trending nearly due west from Temple Mountain has a maximum displacement of about 300 feet. About 7 miles southwest of the town of Green River faults limiting a graben block trend $\mathrm{N} .65^{\circ} \mathrm{W}$. and extend about 4 miles west of the river. The graben block has a synclinal structure with steep dips near the faults, but actual displacement along the faults is 200 feet or less. Mancos shale and the Morrison formation form a floor for the graben block and are faulted against the Morrison formation. These faults are at the northwestern end of a zone of faulting that extends through Moab and Spanish Valleys for a total distance of about 60 miles. (See pl. 20). None of the other faults has a large displacement or is an important feature of the regional geologic structure.

\section{PERIODS OF DEFORMATION}

Several periods of deformation probably affected the rocks of the Green River Desert-Cataract Canyon region to a greater or lesser extent. 6 The first important folding in the decipherable history of the region appears to have occurred either late in the Mississippian or early in the Pennsylvanian. The Paradox and Hermosa formations probably were deposited in a structural basin formed at this time, and probably they overlapped upon structurally and topographically high areas of Mississippian rocks; the westward thinning toward the San Rafael Swell of the Paradox and Hermosa formations, apparently due, in part, to overlap upon rocks of Mississippian age, is believed to reflect this period of folding.

During the Pennsylvanian and Permian the land remained relatively stable. At the close of the Permian there was folding locally, as evidenced by angular discordance observed at a few localities in southeastern Utah. Some elevation of the land occurred, which resulted in erosion at the top of the Permian, as in the San Rafael Swell, and the deposition locally of conglomerate in the base of the Moenkopi, as near the mouth of the Dirty Devil River and in the San Rafael Swell.

In the interval between the deposition of the Lower Triassic Moenkopi formation and the Upper Triassic Shinarump conglomerate, folding occurred locally, but in most of southeastern Utah,

\footnotetext{
${ }^{6}$ Baker, A. A., Geologic structure of southeastern Utah: Am. Assoc. Petroleum Geologists Bull., vol. 19, pp. 1494-1500, 1935.
} 
including the Green River Desert-Cataract Canyon region, there is no evidence of angular discordance between these formations.

A long period of relatively stable conditions, although with some oscillations of the land with respect to sea level and perhaps some regional tilting, continued from Upper Triassic Shinarump time into the Cretaceous. Slight angular discordance has been observed at the top of the Entrada sandstone and at the top of the Summerville formation in the Green River Desert and San Rafael Swell, but it has been observed only in local areas and may not have regional significance.

The major deformation in southeastern Utah occurred after the deposition of the Cretaceous rocks, as all the exposed rocks, up to and including the rocks of Cretaceous age, are everywhere essentially concordant in dip. In the Kaiparowits region, late Upper Cretaceous rocks were tilted and beveled on the flanks of the Circle Cliffs and Kaibab upwarps before the deposition of younger rocks, which were considered by Gregory and Moore to be of the Wasatch formation of early Eocene age. ${ }^{7}$ Although recent work by Spiekers has shown that several periods of folding occurred in central Utah between early Upper Cretaceous and early Tertiary and that the rocks hitherto classified as Wasatch include, in some places, rocks of late Cretaceous age, it is obvious that the folding of the Circle Cliffs and Kaibab upwarps occurred not earlier than very late Cretaceous and probably not later than early Eocene. The San Rafael Swell and the Monument upwarp are analogous to the Circle Cliffs and Kaibab upwarps in magnitude and other characteristics and are inferred to be of the same age. In the western Book Cliffs, which are on the plunging north end of the San Rafael Swell and the flank of the Uinta Basin, rocks of Tertiary age appear to dip concordantly with the older rocks but it seems probable that the dip of the rocks in the Book Cliffs reflects a later period of folding, which resulted in the downwarping of the Uinta Basin, and is not indicative of the age of the folding of the Swell. Most of the smaller structural features of southeastern Utah probably were formed during the period of deformation that caused the regional upwarps.

The Tertiary structural history of southeastern Utah cannot be satisfactorily interpreted because of the absence of rocks younger than the Eocene and because the Eocene rocks have been eroded from most of the region. The downwarping of the Uinta

\footnotetext{
${ }^{7}$ Gregory, H. E., and Moore, R. C., The Kaiparowits region, a geographic and geologic reconnaissance of parts of Utah and Arizona: U. S. Geol. Survey Prof. Paper 164, pl. 2, and pp. 114-116, 1931.

${ }^{8}$ Spieker, E. M., Late Mesozoic and early Cenozoic history of central Utah: U. S. Geol. Survey Prof. paper 205-D, 1946.
} 
Basin involved rocks of late upper Eocene age and may have occurred later than early Miocene. ${ }^{9}$ Another important event in the structural history of the region was the intrusion of the igneous rocks in the isolated mountains, such as the Henry and LaSal Mountains, which is commonly believed to have occurred some time during the Tertiary but has not yet been precisely dated.

A minor but very recent event in the structural history is the development of the arch and its associated faults along the canyon of the Colorado River. These features were formed after the topography of the region had acquired essentially its present form, and the development of the features probably is still in process.

\section{OIL AND GAS \\ HISTORY OF DRILLING}

For nearly 50 years there have been intermittent attempts to discover oil in commercially valuable quantities in southeastern Utah, and many wells have been drilled. Lupton ${ }^{10}$ has given an account of the early activity in the vicinity of the town of Green River, and Prommel ${ }^{11}$ has published a statistical summary of the results of drilling in Utah up to 1935.

One of the first wells drilled in the Green River Desert-Cataract Canyon region was drilled by the California-Utah Oil Co. in 1899 in sec. 5, T. 22 S., R. 15 E., on a local flexure of the rocks at the terminus of a fault. Casing projecting from the ground beside the road from Green River to Hanksville presumably marks the location of this well. It starts in the Mancos shale approximately at the horizon of the Ferron sandstone member and is reported to have been drilled to a depth of 1,600 feet. It therefore passed through about 300 feet of Mancos shale, about 600 feet representing the complete thickness of the Morrison formation, about 130 feet of the Summerville formation, about 75 feet of the Curtis formation, and probably bottomed near the base of the Entrada sandstone or the top of the Carmel formation. Gas, which, when ignited, blazed 30 feet up in the derrick, and a show of oil were reported from a depth of 1,100 feet, which is inferred by the writer to be the depth of the Curtis formation. A sand containing a trace of oil also was reported from the bottom of the hole.

Another well reported to have been drilled in 1899 to a depth of 1,490 feet, in sec. 9,15 , or 16, T. 20 S., R. 14 E., about 13 miles

\footnotetext{
'Bradley, W. H., Origin and microfossils of the oil shale of the Green River formation of Colorado and Utah: U. S. Geol. Survey Prof. Paper 168, p. 6. 1931.

${ }^{10}$ Lupton, C. T., Oil and gas near Green River, Grand County, Utah: U. S. Geol. Survey Bull. 541, pp. 117-121, 1914.

${ }^{11}$ Prommel, H. W. C., Oil and gas development in Utah, 1934: Am. Inst. Min. Met. Eng. vol. 114, Petroleum Development and Technology, 1935, pp. 446-456.
} 


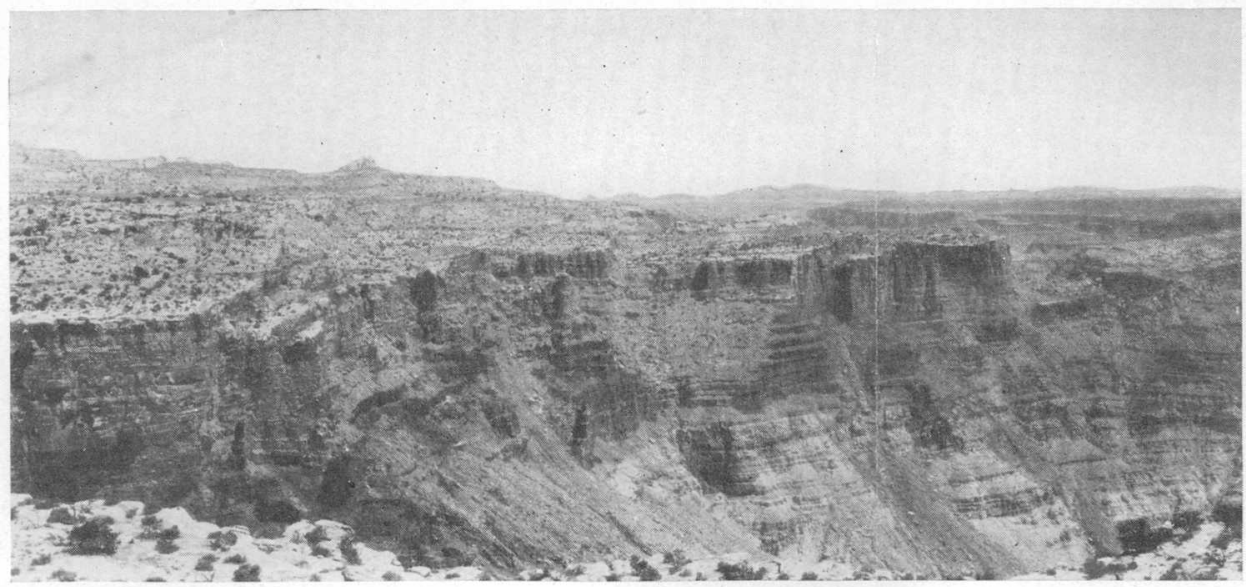

A. WEST WALL OF CATARACT CANYON SOUTHEAST OF WIDE VALLEY.

Shows Hermosa and Rico rocks in eanyon wall and Cedar Mesa sandstone member of Cutler formation, which floors updown (to right) toward river.

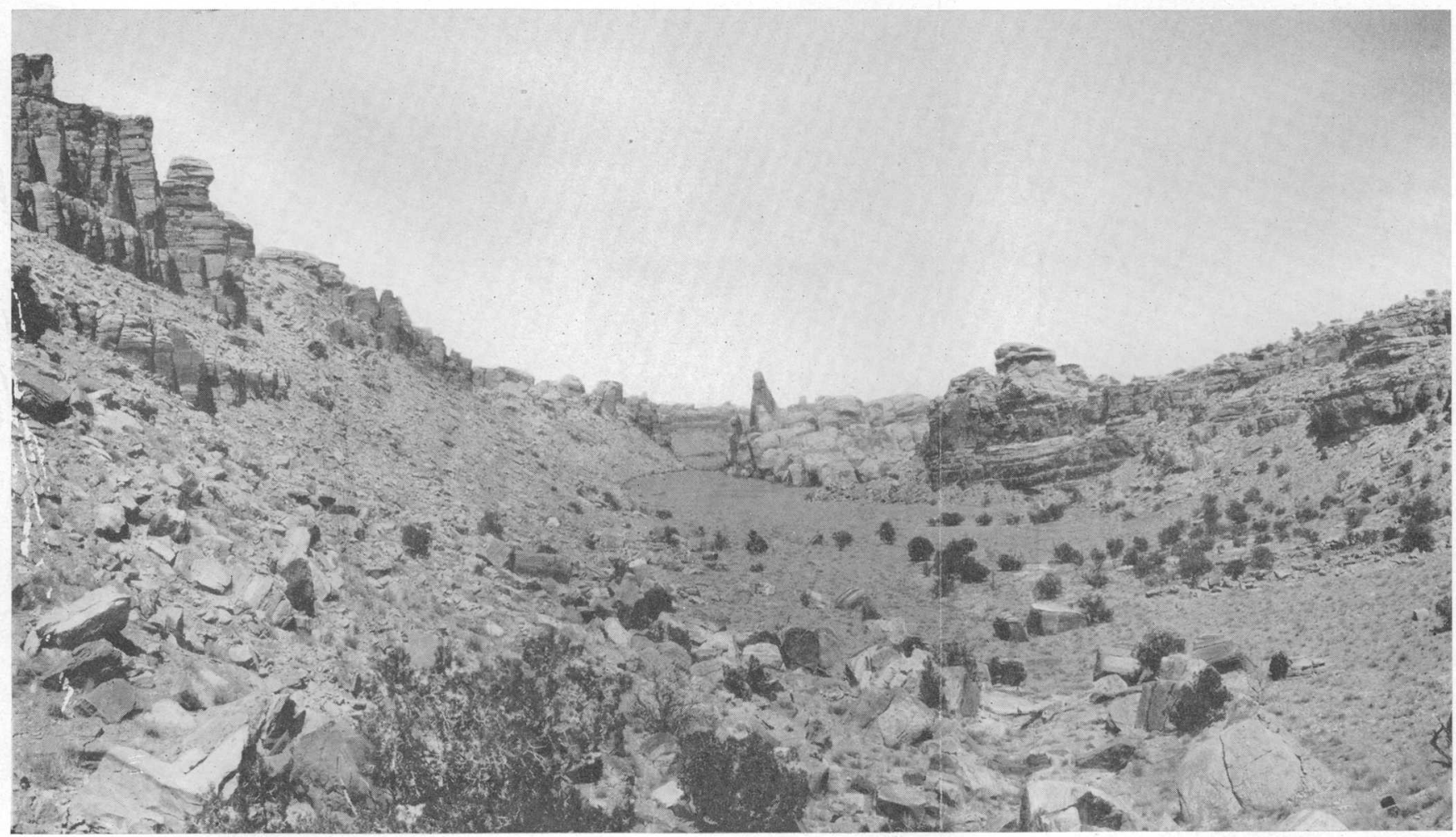

B. VIEW NORTH ALONG SURPRISE VALLEY, A GRABEN VALLEY ADJACENT TO CATARACT CANYON.

Cedar Mesa sandstone member of Cutler formation forms rim rock and underlies valley floor; upper part of Rico formation crops out in valley walls. In right background, a block bounded by the river is inclined toward the observer by movement along a cross fault. 


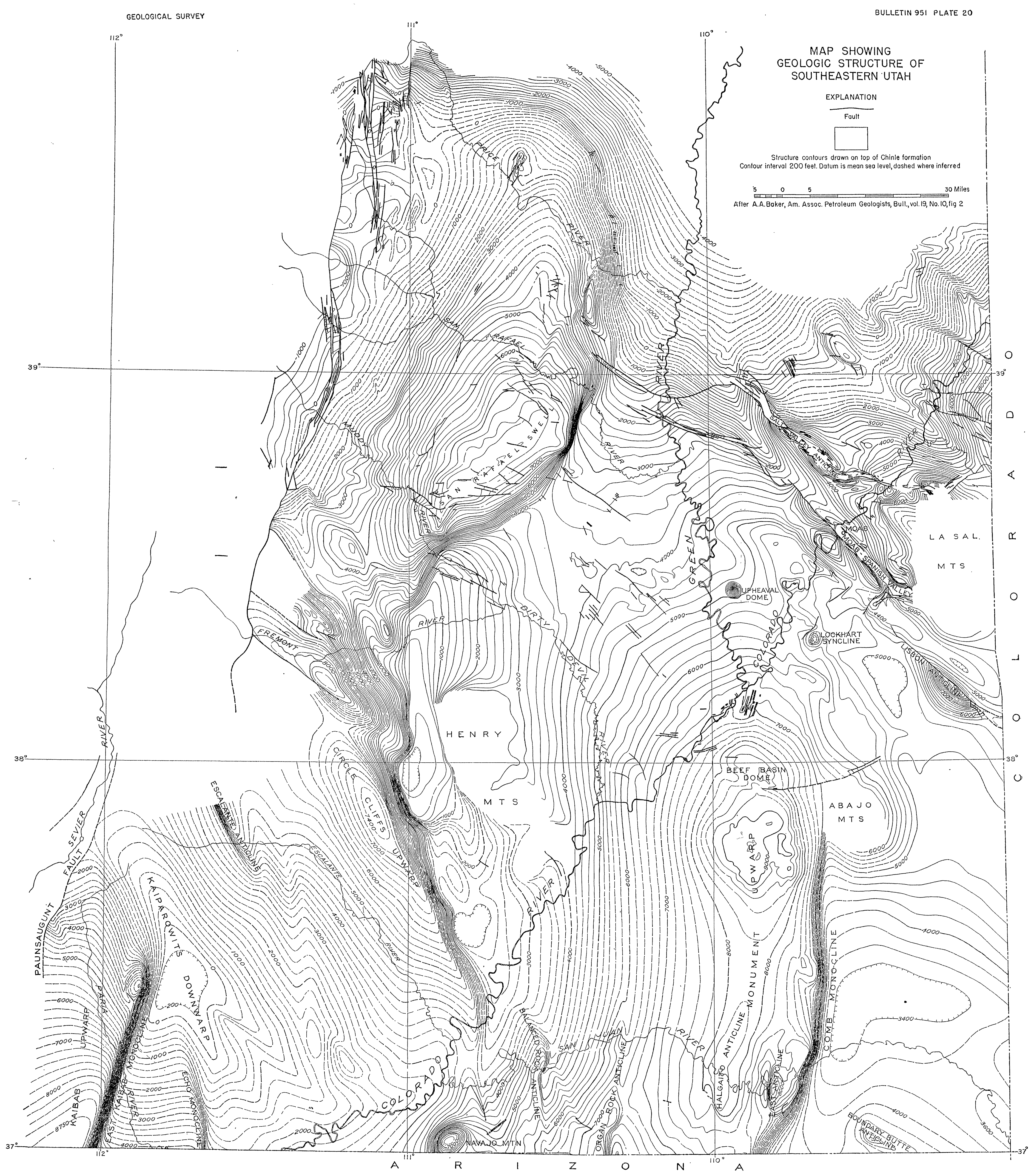


northwest of Green River, was not located by the writer. A definite location for the well is not known, and the surface rocks in secs. 9, 15, and 16 include rocks from upper Morrison to the Ferron sandstone member of the Mancos, so that it is not possible to determine what formations were reached by this well. A showing of oil reported at a depth of 1,100 feet apparently was found either in the Curtis formation or somewhere in the Entrada sandstone. A strong flow of artesian water found in this well between depths of 1,200 and 1,340 feet may have come from the limestones in the basal part of the Carmel that supply water to large springs at several places along the Reef. If the water-bearing horizon is in the Carmel formation the horizon at 1,100 feet in which the showing of oil was found would be at or near the base of the Entrada.

Between 1912 and 1914, a well known locally as the Tasker well was drilled by the Des Moines Oil Co., about 31/2 miles west of the Big Flattop Butte. It is well down on the southwest flank of the Flattop Buttes anticline, and the surface rocks are in the upper part of the Entrada sandstone. Prommel ${ }^{12}$ reports that this well which was drilled to a total depth of 2,910 feet, encountered showings of oil and gas at 2,160 feet in a sand 12 feet thick, some oil and gas at 2,400 feet in a sand 180 feet thick, and oil in two sands at about 2,750 feet. From available information about the thickness of formations in the vicinity of the Flattop Buttes the writer infers that the sand at 2,160 feet may have been the Shinarump conglomerate, that at 2,400 feet a sand in the Moenkopi, and the sands at 2,750 feet either basal Moenkopi or the top of the Coconino sandstone.

Several shallow assessment wells were drilled in Elaterite Basin about 1912 in the vicinity of an oil seep in the White Rim sandstone member of the Cutler formation.

A well that was drilled through a period of several years, in part by the Union Oil Co. of Utah and later by the Texas Production Co., is on the upland surface near French Seep, about 15 miles west of the mouth of the Green River. It was abandoned in 1924 after being drilled to a depth of 2,250 feet. This well, which was drilled on the long monoclinal slope on the flank of the Monument upwarp, started in the Navajo sandstone and probably reached the Organ Rock tongue of the Cutler formation.

A well was drilled by the Carter Oil Co. near the crest of the San Rafael Swell at the head of Iron Wash. Drilling was begun in July 1921, and after neither oil nor gas was found, the well was

\footnotetext{
12 Prommel, H. C., Anticlines on Nequoia Arch, Green River Desert, Utah: Oil Weekly, vol. 47 , no. 11, p. 310,1927 .
}

$697241-46-8$ 
abandoned in February 1922, at a depth of 3,035 feet. The well was begun approximately at the top of the Coconino sandstone and below a depth of about 1,300 feet was drilled in rocks that the writer infers to be of Mississippian age. A driller's log of this well has been published.13

The Texas Production Co. drilled a well near the crest of the Sweetwater dome about 2 miles east of the Big Flattop Butte. Drilling was begun in July 1927, and the well was abandoned in July 1928, at a depth of 2,875 feet. This well started near the top of the Entrada sandstone. A record of the formations encountered and the showings of oil obtained in this well appear on pages $115-116$.

In August, 1928, the Phillips Petroleum Co. began drilling a well near the crest of the Barrier Creek anticline on the Spur, which was drilled to a depth of 5,191 feet without encountering oil or gas and was abandoned in August, 1929. The well started in the upper part of the Navajo sandstone. A record of the formations encountered in this well appears on pages 113-115.

Since the completion of field work for this report, two wells were drilled by the Standard Oil Co. of California near the crest of the San Rafael Swell. Their locations are not shown on the map, plate 1. San Rafael Unit well No. 1 is reported to be in the SW $1 / 4$ SW $1 / 4$ sec. 22 , T. 23 S., R. 11 E. It started in the Kaibab limestone and was drilled to a total depth of 2,285 feet from August to October 1936. The San Rafael Unit well No. 2, reported to be in the center of the NW1/4 NW1/4, sec. 27, T. 23 S., R. 11 E., was started in April, 1937, and was abandoned in July 1937 after reaching granite. The well started near the top of the Coconino sandstone and was drilled to a total depth of 4,900 feet without finding oil or gas. A composite record of these wells from an examination of cutting appears on pages 117-120.

A few of the deeper wells drilled in neighboring areas provide data that are useful in considering the oil and gas possibilities of the Green River Desert-Cataract Canyon region. The Mount Vernon Oil Co. well in sec. 4, T. 27 S., R. 12 E., about 5 miles southwest of the Des Moines well, was drilled about 1914, far down on the southwest flank of the Flattop Buttes anticline. It was reported 14 to have been drilled to a depth of 2,715 feet and to have found showings of oil at 2,175, 2,530, and 2,655 feet below the surface. This well started near the top of the Entrada sandstone and the showings of oil probably were from the Shinarump

${ }^{13}$ Gilluly, James, Geology and oil and gas prospects of part of the San Rafael Swell, Utah: U. S. Geol. Survey Bull. 806, p. 129, 1929.

${ }^{14}$ Clark, F. R., The Farnham anticline, Carbon County, Utah: U. S. Geol. Survey Bull. 711, p. 11, 1920 . 
conglomerate and the Moenkopi formation at horizons similar to those encountered in the Des Moines well. In 1921, the Ohio Oil Co. drilled a well to a depth of 3,212 feet on the top of the Circle Cliffs upwarp (see pl. 20) without finding oil or gas. The well started in the Kaibab limestone. The writer is unable to interpret the record ${ }^{15}$ of this well but suspects that much of the deeper drilling was in rocks of Mississippian age. In 1921-22, the Ohio Oil Co. drilled another well on the Caineville anticline, a subsidiary fold at the south end of the San Rafael Swell. The well started in the Entrada sandstone and reached the Coconino sandstone at a depth of 3,650 feet, but no oil or gas was found. The Woodside anticline, another subsidiary fold on the east flank of the San Rafael Swell near its north end, was drilled by the Utah Oil Refining Co. in 1923-24. Gilluly ${ }^{16}$ reports that this well commenced at the top of the Curtis formation and probably reached the Coconino sandstone. It was drilled to a depth of 3,375 feet and obtained showings of gas at 1,940 to 1,945, 2,155 to $2,165,2,845,2,970$, and 3,120 to 3,165 feet. The gas at 3,120 to 3,165 feet was a strong flow, which Gilluly interpreted to be from the upper part of the Coconino; it was found to be chiefly carbon dioxide containing helium in notable quantities. The Marland Oil Co. drilled a well to a depth of 3,820 feet near the town of Green River in sec. 35, T. 21 S., R. 16 E., in 1925-26. The well is on a faulted anticlinal nose. It started in the Morrison formation and, according to McKnight, ${ }^{17}$ reached the lower Cutler or the Rico formation. At several horizons, showings of oil or gas were obtained, which McKnight interpreted as a showing of oil at about 400 feet-probably Morrison; a showing of gas at 1,500 to 1,530 feet-Kayenta formation; a showing. of oil at 2,396 feet-Shinarump conglomerate; a showing of gas at 2,630 feet and a showing of oil at 2,630 to 2,645 feet-Moenkopi formation; a showing of oil at 3,060 to 3,070 feet and a showing of gas at 3,170 to 3,180 feet-Coconino sandstone. Another well was drilled in sec. 34, a short distance west of the Marland well, by Glen Ruby and associates in 1935-36. This well was drilled to a depth of 2,627 feet to the top of a dense cherty limestone that probably is at the approximate horizon of the Kaibab limestone. Oil or gas showings were obtained at several horizons. principally in the upper 500 feet. The Midwest Exploration Co. drilled a well in Dark Canyon at the crest of the Monument upwarp in 1926-27.

\footnotetext{
${ }^{15}$ Gregory, H. E., and Moore, R. C., The Kaiparowits region, a geographic and geologic reconnaissance of parts of Utah and Arizona: U. S. Geol. Survey Prof. Paper 164, p. 157, 1931.

${ }^{16}$ Gilluly, James, op. cit., p. 129.

${ }^{17}$ McKnight, E. T., Geology of area between Green and Colorado Rivers, Grand and San Juan Counties, Utah: U. S. Geol. Survey Bull. 908, 1940 [1941].
} 
They drilled to a depth of 4,422 feet, through a thick series of limestone beds into granite, without finding oil or gas. As in the wells drilled in the San Rafael Swell and the Circle Cliffs upwarp, it is inferred that the lower part of this well was drilled through a considerable thickness of Mississippian and perhaps older rocks. The Ramsey Petroleum Corporation drilled a well on the Last Chance or Starvation Creek anticline, a subsidiary fold at the south end of the San Rafael Swell, through a period from 1931 to 1936. The surface rock on the crest of the anticline is the Carmel formation. The well was drilled to a depth of 3,168 feet and is reported to have encountered flows of 4 million cubic feet of petroleum gas at a depth of 2,698 feet and 21 million cubic feet of gas at a depth of 2,775 feet, both from the Moenkopi formation, and good showings of oil at 2,800 and 3,071 feet. It is not known whether these oil showings were obtained from the Moenkopi formation or from the Kaibab limestone or the Coconino sandstone.

\section{POSSIBILITY OF OIL AND GAS PRODUCTION}

Oil seeps or outcrops of bituminous sandstone at numerous places in southeastern Utah have caused that part of the State to be considered for many years as favorable territory for prospecting for oil and gas. Wells drilled up to the present time have failed to disclose large accumulations of oil, but as a few wells have yielded small quantities of oil and some gas and many other wells have obtained showings of oil at one or more horizons, the idea has persisted that somewhere in that part of the State important production of oil would be obtained.

Rocks older than the Pennsylvanian crop out at distant localities, as in the Grand Canyon in Arizona, in western Colorado, and in western and northern Utah, but there is little or no indication that these rocks might be petroliferous in southeastern Utah; a few deep wells drilled in the southeastern part of the State, which are believed to have reached pre-Pennsylvania sedimentary rocks have failed to show strong indications of oil. Most of the wells drilled into the Paradox formation, of Pennsylvania age, have yielded some showings of oil and gas. The most impressive was obtained in a well drilled on the Cane Creek anticline on the Colorado River a few miles below Moab; a green parafin-base oil, with a gravity of $36^{\circ}$ Baume', and some gas gushed from the well, but the operators were unable to control water from a higher horizon and finally abandoned the well. Wells subsequently drilled on the Cane Creek anticline have failed to obtain such promising showings of oil or gas. The Green River DesertCataract Canyon region straddles the western margin of the basin of deposition of the Paradox formation. Neither the Phillips 
Petroleum Co. well, which passed through a series of beds representing a thin marginal facies of the formation, nor the wells drilled on the San Rafael Swell, which did not encounter any rocks correlatable with the Paradox formation, found indications of oil or gas to suggest that near-shore conditions of deposition provided more abundant oil-forming substances or a stratigraphic trap to control accumulation. The Hermosa formation, also of Pennsylvanian age, has provided showings of oil and gas in a few wells drilled in the vicinity of Moab and together with the overlying Rico formation of Permian age has produced a small quantity of oil near Mexican Hat on the San Juan River; the Hermosa also is believed to be the producting formation at a depth of about 6,700 feet in the Rattlesnake field in northwestern New Mexico. ${ }^{18}$ Neither the Hermosa nor the Rico formation have provided strong showings of oil or gas in the wells that have been drilled into them along the Colorado River, or on the Barrier Creek anticline, the San Rafael Swell, or the Circle Cliffs and Monument upwarps. Because of the absence of strong showings of oil or gas in such wells and the scarcity of oil seeps or oilsaturated beds at outcrops in the country adjoining the Green River Desert-Cataract Canyon region, those formations probably are not a likely source of oil or gas in that area.

The tops of the Cedar Mesa sandstone and the White Rim sandstone, both members of the Cutler formation, are bituminous at many outcrops in the southern part of the area, and a black asphaltlike substance seeps from the White Rim sandstone in Elaterite Basin west of Elaterite Butte between Horse and Big Water Canyons.' The upper part of the Coconino sandstone in the San Rafael Swell locally contains petroleum residue and the Kaibab limestone at the top of the Permian in the San Rafael Swell also contains bituminous matter as coatings or particles in geodes. The Des Moines well and the Marland well east of Green River have provided showings of oil from rocks interpreted to be the upper part of the Permian, and the gas in the Woodside anticline is said to be derived from rocks of about the same age.

Rocks of Triassic age also have provided abundant showings of oil and gas. The lower part of the Moenkopi formation contains beds saturated with petroleum at several places in the area, as on the south side of the Cove, at the main forks of Hatch Canyon, and in Black Dragon Canyon. Many wells, including the Des Moines well, the Texas Production Co. well on Sweetwater Dome, the Mt. Vernon Oil Co. well, the Marland Oil Co. well, and the

\footnotetext{
${ }^{18}$ Baker, A. A., Geology of the Monument Valley-Navajo Mountain region, San Juan County, Utah: U. S. Geol. Survey Bull. 865, pp. 93-94, 1936.
} 
well on the Woodside anticline obtained showings of oil or gas from the Moenkopi. The Ramsey Petroleum Corporation obtained a flow of 21 million cubic feet from the Moenkopi on the Starvation Creek anticline. The Shinarump conglomerate also is bituminous at a number of places at its outcrop and where encountered in wells. The outcrops are bituminous locally in the San Rafael Swell, as at Temple Mountain. Showings of oil were obtained in the Des Moines, Mount Vernon, and Marland wells and in the Texas well on Sweetwater dome from rocks correlated with the Shinarump.

The rocks of the Glen Canyon group, of Jurassic (?) age, are of continental origin and are not known to have given any indications of containing oil or gas except for a small showing of gas obtained. in the Marland well from' rocks interpreted to be the Kayenta formation. The Jurassic rocks of the San Rafael group are locally impregnated with oil and have yielded some showings of oil and gas in wells. McKnight ${ }^{19}$ has described the impregnation of the Entrada sandstone east of the Green River in the vicinity of Tenmile Wash and the occurrence of a little oil and gas, possibly from the Entrada, in a well drilled in sec. 25, T. 23 S., R. $18 \mathrm{E}$. The base of the Curtis and the top of the Entrada are petroliferous at several places in the vicinity of the Sweetwater dome. Showings of gas and oil that may have been from the Curtis formation were obtained in the California-Utah Oil Co. well in sec. 5, T. 22 S., R. 15 E., and from the Curtis or Entrada in the well drilled in T. 20 S., R. 14 E. The Morrison formation, also of Jurassic age, is reported ${ }^{20}$ to have bituminous sandstone at its outcrop a few miles east of the Green River, and a slight show of oil was obtained from the Morrison formation at a depth of 400 feet in the Marland well.

Although showings of oil have been obtained at several horizons in rocks that are present in the Green River Desert-Cataract Canyon region, the showings from a relatively thin series, including the upper part of the Permian and the lower part of the Moenkopi, appear strongest; the rocks of this thin series therefore are considered to be the most likely reservoirs for accumulations of oil or gas in commercial quantities. These rocks crop out at the surface on the crest of the San Rafael Swell and therefore offer no possibilities of production from the highest part of the main fold. When buried beneath younger rocks, the Permian or Triassic rocks have produced gas from structurally lower subsidiary folds on the flanks of the Swell at Farnham, Woodside, and

\footnotetext{
${ }^{19}$ McKnight, E. T., Geology of area between Green and Colorado Rivers, Grand and San Juan Counties, Utah: U. S. Geol. Survey Bull. 908, 1940 [1941].

${ }^{20}$ McKnight, E. T., op. cit.
} 
Starvation Creek but have failed to yield either oil or gas on the structurally still lower Caineville anticline. (See pl. 20.) Both the Flattop Buttes and the Barrier Creek anticlines, which appear to be the most favorable structural traps within the area for the accumulation of oil or gas, have been drilled to the Permian without obtaining production.

\section{RECORDS OF WELLS}

The records of three of the wells drilled in the area are given on the following pages. The record of the wells drilled on the San Rafael Sweil by the Standard Oil Co. of California is based upon an examination of cuttings from those wells by the writer. The lithologic descriptions in the records of the other wells are those given by the drillers. Interpretations of formation boundaries have been made by the writer.

Record of Phillips Petroleum Co. well No. 1 drilled on the Spur on the Barrier Creek anticline

Navajo sandstone:

Red sandstone.

Thickness Depth

Red sandstone... (feet)

(feet)

Light sandstone

205

205

Red sandstone.

Kayenta formation:

Red shale

Red sandstone

Red hard sandstone.

Red hard sandy limestone

Wingate sandstone: Red hard and soft sandstone

Chinle formation:

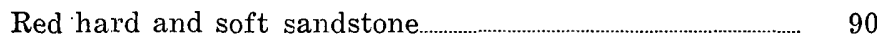

Red soft rock

Hard red rock and limestone.

Hard red broken limestone

Red soft rock

Hard red limestone and red rock

Hard red limestone and sandstone

Soft red limestone and shale.

Gray hard limestone

Red hard limestone and red rock.

Red soft limestone and red rock...

Gray hard limestone.

Red soft limestone and red rock...

Shinarump conglomerate:

Gray hard sandstone

Gray shale

Gray hard sandstone.

Gray hard sandy limestone...

Gray soft sandstone. 
Moenkopi formation:

Thickness (feet)

Soft red rock

Soft blue shale.

Sandy limestone

Sandstone

Broken limestone

Sandy limestone

Blue shale

Limestone

Gray hard sandy limestone.

Limestone

Sandy limestone

Limestone

Pink limestone

Brown limestone.

Red limestone.

Brown limestone.

Red limestone...

Red shale

Limestone and shale

Red limestone.

Gray limestone...

Red limestone.

White Rim sandstone member of the Cutler formation:

Gray sandstone.

Brown sandstone

White sandstone

Lower part of Cutler formation:

Red sandstone.

Rico and Hermosa formations undifferentiated:

Limestone and sandstone

Red limestone

Sandy limestone

Brown sandstone

Limestone and sandstone

Blue limestone.

Red sandy shale.

Brown and gray limestone and sandstone.

White sandstone.

Sandy limestone

Gray limestone

Gray sandstone.

Sandy limestone.

Black limestone.

Gray limestone

sandy limestone.

Limestone

Black mud.

Gray limestone.

Sandy limestone.

Blue slate

Sandy limestone
Depth

(feet)

1,395

1,510

1,525

1,540

1,545

1,555

1,565

1,600

1,655

1,693

1,695

1,745

1,765

1,780

1,800

1,815

1,850

1,860

1,895

1,$91 ;$

1,920

1,940

1,955

1,990

2,310

2,555

2,590

2,600

2,618

2,635

2,695

2,705

2,715

2,855

2,885

2,892

2,910

2,945

2,960

2,965

2,970

2,980

3,031

3,034

3,044

3,048

3,051

3,058 


\begin{tabular}{|c|c|c|}
\hline & $\begin{array}{c}\text { Thickness } \\
\text { (feet) }\end{array}$ & $\begin{array}{l}\text { Depth } \\
\text { (feet) }\end{array}$ \\
\hline Blue slate.... & 19 & 3,077 \\
\hline Limestone and slate.... & 49 & 3,126 \\
\hline Limestone & 32 & 3,158 \\
\hline Sandy limestone..... & 19 & 3,177 \\
\hline Blue slate & 3 & 3,180 \\
\hline Gray hard limestone. & 3 & 3.183 \\
\hline Slate and gray hard limestone.... & 24 & 3,207 \\
\hline Blue hard slate & 10 & 3,217 \\
\hline Slate and gray hard limestone & 9 & 3,226 \\
\hline Sandy gray hard broken limestone..... & 9 & 3,235 \\
\hline Blue shale and slate & 30 & 3,265 \\
\hline White hard limestone & 10 & 3,275 \\
\hline Blue soft slate. & 12 & 3,287 \\
\hline Broken gray hard limestone...... & 10 & 3,297 \\
\hline Sandy gray hard limestone............. & 10 & 3,307 \\
\hline Blue soft limestone & 10 & 3,317 \\
\hline 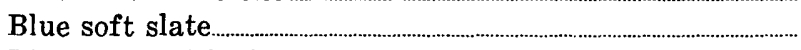 & 7 & 3,324 \\
\hline Limestone with shale and slate..... & 7 & 3,331 \\
\hline Gray hard limestone & 29 & 3,360 \\
\hline Limestone and shale, black, soft..... & 10 & 3,370 \\
\hline Sandy gray hard limestone & 63 & 3,433 \\
\hline Gray hard limestone. & 6 & 3,439 \\
\hline Hard gray limestone with gray sandstone and shale......... & 47 & $3 ; 486$ \\
\hline Gray hard sandstone & 19 & 3,505 \\
\hline Corrected depth & & 3,497 \\
\hline Gray and brown sandstone.... & ... 113 & 3,610 \\
\hline Gray and brown hard limestone & 30 & 3,640 \\
\hline Hard black broken limestone & 10 & 3,650 \\
\hline Gray to brown hard limestone.... & 450 & 4,100 \\
\hline
\end{tabular}

Paradox formation: Described by driller as white to brown limestone with some soft black shale and with some light hard sandstone in interval 4,775-4,804 feet, but cuttings were reported to contain a good deal of anhydrite

Mississippian? rocks: Described by driller as white to gray hard limestone in part sandy with a gray soft sandstone at $5,139-5,143$ feet, but cuttings reported to be a creamy, pearly, platy dolomite

Record of Texas Production Co. well No. 1 drilled on the Sweetwater dome near the Flattop Buttes

Thickness Depth (feet) (feet)

Entrada sandstone: Red rock and red sandstone with some white sandstone.

Carmel formation:

White sand .

Red rock and white sandstone.

Red rock and white sandstone...

Red and white shale.

Red rock 
Thickness

White soft sandstone........................................................................ $\quad \begin{array}{r}\text { (feet } \\ 5\end{array}$

Conglomerate .......................................................................................................... 35

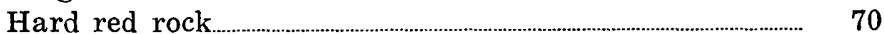

5700

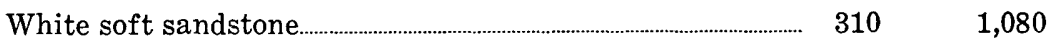

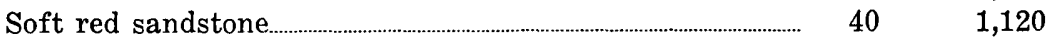

Kayenta formation:

White sandstone...

Red sandstone, water .................................................................................... $\quad 85$

1,200

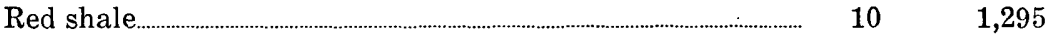

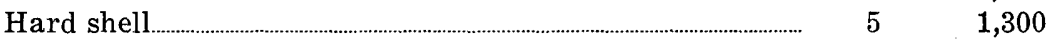

Red sandstone, water.......................................................................... $15 \quad 1,315$

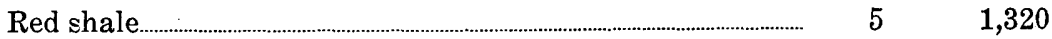

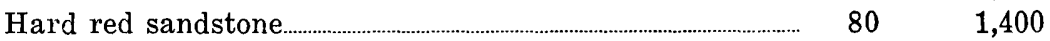

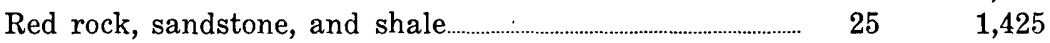

Wingate sandstone:

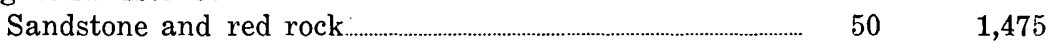

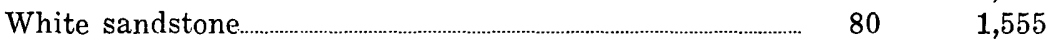

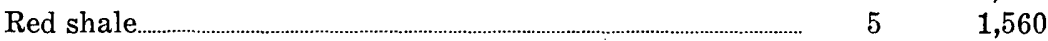

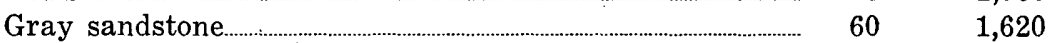

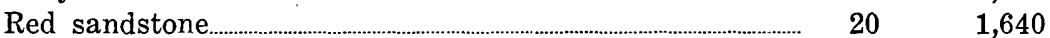

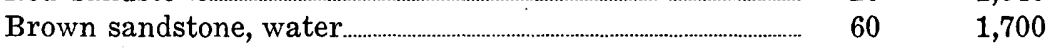

Chinle formation:

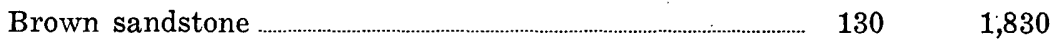

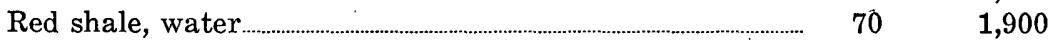

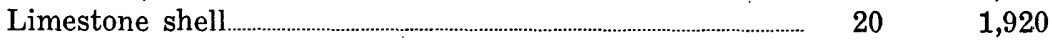

Red rock ......................................................................................... $80 \quad 2,000$

White hard sandstone................................................................................. $10 \quad 2,010$

Conglomerate.

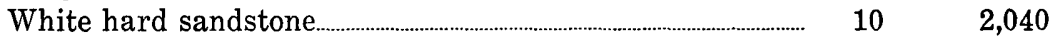

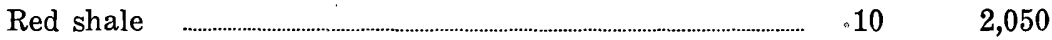

Varicolored conglomerate .......................................................... $35 \quad 35$

Red shale ........................................................................................... $35 \quad 2,120$

Varicolored conglomerate ……......................................................... $48 \quad 2,168$

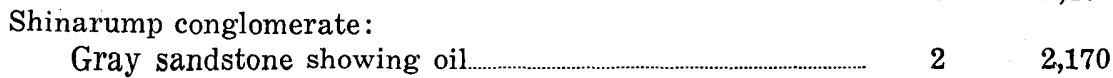

Hard gray sandstone with heavy black oil................................... $25 \quad 2,195$

Moenkopi formation:

Red shale.

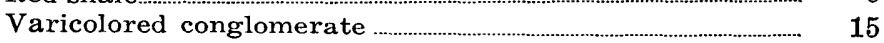

Gray and green shale

Hard blue limestone.............................. 25

Grayish-green shale................................................................................... $\quad 35$

Brown limestone and sandstone .............................................................. $\quad 30$

Broken sandy gray limestone, small show of dead oil.......... $\quad 35 \quad 2,490$

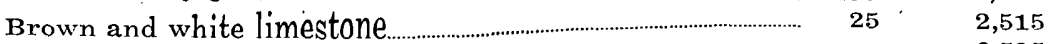

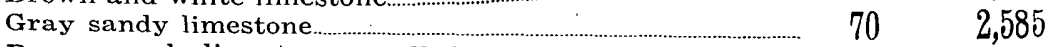

Brown sandy limestone, small show of dead oil............................ $20 \quad 20 \quad 2,605$

Gray limestone ........................................... $70 \quad 2,675$

Hard gray sandy limestone, show of heavy black oil........ $55 \quad 2,730$

Coconino sandstone:

Brown sandstone, water.

White sandstone, water. 
Composite record from examination of well cuttings of two wells drilled on the San Rafael Swell by the Standard Oil Co. of California

[San Rafael Unit well No. 1 in the SW1/4 sec. 22, T. 23 S., R. 11 E. supplied the cuttings to a depth of 2,285 feet and San Rafael Unit well No. 2 in the NW1/4 sec. $27, T$. 23 S., R. 11 E. supplied the cuttings below that depth]

Kaibab limestone: No sample..

Thickness (feet)

Coconino sandstone:

Sandstone, fine- to medium-grained, grains angular to well rounded

No sample

Sandstone like above

No sample.

Gray sandstone, poorly sorted.

No sample

Gray sandstone like above

No sample.

Rico and Hermosa formations undifferentiated:

Grit and fine conglomerate, grayish brown with matrix of rounded quartz grains and flat pebbles of finegrained limy gray sandstone.

No sample

Fine-grained gray sandstone with some light-gray limestone

No sample

Light-gray, very fine- to coarse-grained sandstone with abundant lime cement, some flakes of darker-gray limy sandstone

No sample

Fine- to medium-grained light-gray sandstone with abundant lime cement, has pink to red tinge in lower part...

Light to medium gray, fine- to coarse-grained limy sandstone with some gray sandy limestone.

Light-gray to pink sandy limestone.

Mississippian(?) rocks possibly including rocks of Devonian age or older in the lower part:

Light-gray, white, and pinkish, coarsely crystalline dolomite-one piece of anhydrite in sample from 1,2801,290 feet.

Light-gray to pink, coarsely crystalline dolomite with some flakes of gray sandy limestone and chert...

Buff sandstone, light- to dark-gray dolomite, some gypsum and chert

Light- to medium-gray to pinkish sandy limestone

Pink to gray, dense to coarsely crystalline dolomite, gray sandy dolomite, dark purplish-brown dolomite and limy sandstone.

Red sandstone and gray to purplish-brown dolomite.

Light-gray to purplish-brown dolomite and sandy dolomite with some chert-contains ostracods...

Pinkish red fine-grained sandstone

Iron-stained gray dolomite with a few pieces of red sandstone.
20

Depth (feet) 
Red sandstone fines with chips of brownish-lavender and light-gray coarsely crystalline dolomite.

ight-gray and brownish-lavender, coarsely crystalline dolomite, with some red sandstone and greenish siltstone.

Pinkish light-gray to medium-gray coarsely crystalline dolomite with some chert and anhydrite.

Light-gray dolomite with a few pieces of red sandstone...

Sandstone with light- to dark-gray dolomite, considerable gypsum and a little anhydrite.

Pink to gray dolomite and red and gray sandstone.

White to pink, coarsely crystalline do'omite with some dense dark gray dolomite, chert, red-brown and gray fine-grained sandstone and light-gray limestone.

White to pink dolomite containing some dense gray sandy limestone and a few chips of sandstone.

Medium-gray to pinkish dolomite with occasional chips of greenish-gray siltstone, coarse-grained gray sandstone and chert (a little white gypsum at 1,900-1,910 feet)

Light-gray to medium-gray dolomite with chips of greenish-gray shale and sandstone, some pink limestone, abundant gray chert

Light pinkish-gray to medium-gray dolomite with abundant light-gray chert.

Light-gray chert and medium-gray dolomite with some light brownish-gray fine-grained gritty sandstone..

Buff sandstone, flesh-colored crystalline dolomite, some chert

Light brownish-gray dolomite.

Light-gray crystalline dolomite, some flesh-colored dolomite, buff to gray fine-grained sandstone and greenishgray shale.

Light brownish-gray iron-spotted dolomite with some gray chert

Light-gray dolomite with considerable sandstone fines and some greenish-gray fine-grained sandstone.

Light-gray dense to coarsely crystalline dolomite with some weathered chert; one fossil fragment.

White to gray crystalline dolomite with a few fragments of greenish-gray siltstone

White to medium-gray, coarsely crystalline dolomite............

White to medium-gray, coarsely crystallice dolomite with numerous fragments of greenish-gray fine-grained sandstone

White to medium-gray, coarsely crystalline dolomite.

White to medium-gray crystalline cherty dolomite with gray to greenish-gray fine-grained sandstone

Medium-gray, white, and flesh-colored dolomite with a few chips of fine-grained greenish-gray sandstone. 


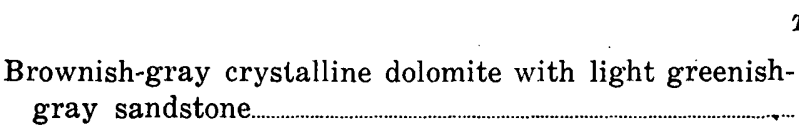

Brownish-gray dense limestone with some chert and some greenish-gray sandstone and siltstone.

Thickness (feet)

Dept.

(feet,

80

2,390

120

2,510

Light-gray to flesh-colored and dark-gray dolomite with some green shale and greenish-gray.sandstone...

Light-gray coarse-grained sandstone, greenish-gray siltstone, some red siltstone, and some light- and darkgray dolomite.

Flesh-colored to gray dolomite with some light-gray sandstone, chert, greenish-gray siltstone, and some white fibrous gypsum.

Gray to flesh-colored dolomite, some sand grains, some red and gray chert and abundant greenish-gray siltstone.

Light-gray sandstone with gray to flesh-colored cherty dolomite and some greenish-gray siltstone

Gray to flesh-colored dolomite with some red and gray sandstone and greenish-gray siltstone.

Dark-gray shale or slate with abundant pieces of a gray to pink igneous rock. These samples are like those from near bottom of hole and may have been mixed.

Gray to flesh-colored cherty dolomite, light-gray quartz sandstone, some chert and greenish-gray siltstone.

Light to flesh-colored dolomite with some fine-grained red sandstone and greenish-gray siltstone

Sandstone, fine-grained, with abundant greenish-gray siltstone and gray dolomite.

Brownish-gray to flesh-colored, dense to coarsely crystalline dolomite.

Brownish-gray to flesh-colored dolomite with some brown sandstone

Brownish-gray to flesh-colored dolomite with some fibrous gypsum

Dark brownish-gray dolomite with one piece of red sandstone seamed with gypsum

Light- to brownish-gray crystalline dolomite

Light- to brownish-gray crystalline dolomite with one piece of anhydrite.

Light brownish-gray crystalline dolomite...

Nearly white dolomite.

Dark brownish-gray crystalline dolomite.

Dark brownish-gray crystalline dolomite with some fibrous gypsum

Dark brownish-gray crystalline dolomite

Dense to crystalline gray limestone.

Dark-gray dolomite

Dark-gray dolomite with abundant greenish-gray siltstone.

Dark- to light-gray limestone with abundant dark-gray shale. 
Light-gray limestone.

Grayish-brown dolomite and dark-gray shale...

Light- to medium-gray dense limestone...

Gray to white crystalline dolomite.

Dense to coarsely crystalline brownish-gray dolomite, considerable dark-gray shale.

Brownish-gray to gray dolomitic limestone mottled with brown spots, some coarsely crystalline dolomite.

Like above, with much gray shale.

Dense, very light-gray limestone.

Light- to medium-gray limestone mottled with brown spots, considerable dark-gray shale.

Dense brownish-gray limestone.

$20 \quad 3,910$

Gray to brownish-gray, dense to coarsely crystalline limestone with dark-gray shale and some fine-grained gray sandstone and siltstone.

Gray limestone with much fine-grained micaceous gray sandstone

Fine-grained dull red-brown and gray micaceous sandstone

Fine-grained dark-gray micaceous sandstone and shale...

Fine-grained dark-gray micaceous sandstone and siltstone with some greenish-black contorted shale; contains fish scales..

Fine-grained medium- to dark-gray sandstone with abundant ferromagnesian minerals, some contorted greenish shale; contains fish scales or plates.

Like above but no fish remains observed.

Like above, with abundant fine-grained white sandstone...

Dark-gray siltstone, white to buff fine-grained sandstone and green contorted shale.

Medium-gray siltstone or shale with some green contorted shale

Like above, with some gray sandstone

Gray siltstone with green contorted shale and pale violetred sandstone

Like above, with a few flakes of light-gray limestone...........

Like above, with more abundant red sandstone.

Fine-grained dark gray siltstone, violet-red to white sandstone and a few flakes of brownish-gray limestone Coarse red sandstone and gray siltstone.

Coarse red sandstone and gray sandstone with a little pinsk foldspar 


\section{INDEX}

\section{Acknowledgments}

Barrier Creek anticline, description of.....

Big Flattop Butte dome, description of... 98-99 Black Ledge, features of

Black Rim, location of $7-8$, pl. $10, A$

Bluejohn anticline, description of.................99-100

Carmel formation, distribution of ........ 70 pls. $6,17, A$

fossils in 74-75

lithology of $70-73$

stratigraphic relations of ..................73-74, pl. 17

Cedar Mesa sandstone, distribution of ...... 37-38,

lithology of

pls. $5, B, 6,9, A$

section in

$38-39$, pl. $9, B$

stratigraphic relations of

\section{9}

hinle formation, distribution

60

fossils in

pls. $6, B, 12, B, 14$

fossils in

$60-61$

section in ...................................................61-62

stratigraphic relations of .......................... 62-63

Climate of the area .................................................... 15-16

Coconino sandstone, distribution of .............. 48-49,

lithology of

pls. 14,16

stratigraphic relations of.

pls. 14,16

49
46

Colorado River, description of

Curtis formation, distribution of

fossils in

lithology of

49-50

stratigraphic relations of $\cdots \cdots \cdots \cdots \cdots \cdots \cdots \cdots$

Cutler formation, distribution of .................. $\quad 36$

lithology of ........................................................36-37

stratigraphic relations of ........36 37, pls. 7, 8

Dakota (?) sandstone, distribution of......

fossils in

90

lithology of

stratigraphic relations of.. 90-91

Deformation in the area, periods of.

Dirty Devil River, description of. 91

Drainage in the area

$9-10$

Drilling in the area, history of....................106-110

Entrada sandstone, distribution of _.......... 75-76 lithology of .................................76-78, pl. 17,C

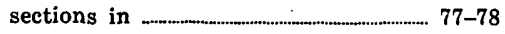

stratigraphic relations of.........78-80, pl. 18, $A$

Expeditions to the area 19-20

Farming in the area

Faults in the area, features of.......103-104, pl. 20 Field work in the area...................................... 5-6 Flattop Buttes anticline, description of...... 98-99
Girty, G. H., fossils identified by...................... $\quad 52$

Glen Canyon group; features of.................... 63-69

Green River, description of .................................. $\quad 9-10$

Hermosa formation, distribution of ............ 27, pls. $4, A, 5, A, 6, A$

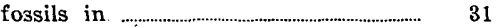

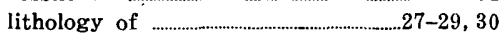

sections in.......................................................28-29, 30

stratigraphic relations of.......................29, 30-31

Kaibab limestone, distribution of .................. 50

fossils in ....................................................... 51-52

lithology of ..................................................... $50-51$

section in ............................................................. 51

stratigraphic relations of .............................. $52-53$

Kayenta formation, distribution of............. 65-66

pls. $10, B, 14$

fossils in

67

lithology of .............................................................. 66-67

stratigraphic relations of .............................. $\quad 67$

Knowlton, F. H., fossils identified by ........... 91

Ledge, features of ..................................................... 64

Location of the area............................................. . 3-4

Mancos shale, distribution of ............................. 91-92

fossils in........................................................ 92

lithology of ........................................................... 91-92

Moenkopi formation, distribution of ........ ' 54 , pls. $6, \mathrm{~B}, 10, \mathrm{~B}, 11, \mathrm{~B}, 12, \mathrm{~B}, 13,14$

lithology of ................................................. 54-57 sections in .................................................55-57

Monument upwarp, description of...........97, pl. 20

Morrison formation, distribution of ........... 86-87,

pl. $18, A$

lithology of .............................................. 87-89

section in ............................................................ 88-89

stratigraphic relations of ............................ 89-90

Navajo sandstone, distribution of .................... 67-68,

lithology of ....... pls. 10,B, 14, 16

stratigraphic relations of.................69, pl. 17, $A$

Oil and gas production, possibility of.........110-113

Organ Rock tongue, distribution of ......... 40-41,

pls. $9, A, 10,11, A$

lithology of 41-44,

pls. $7,8,9, A, 10,11, A$

sections in ............................................. $41-42$

stratigraphic relations of ............................... 43-44

Paradox formation, distribution of......23-24, pl. 1 folds and faults in relation to flowage in ....................101-103, pls. 19, 20

fossils in

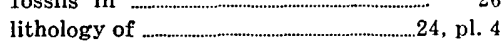

stratigraphic relations of........................... 24-27

Population of the area........................................ 16-18

Publications on the area, list of ...................... 19-21 


\section{INDEX}

Red Rim, location of.

Reef, features of 8 , pl. 16

Reeside, J. B., Jr., fossils identified $63,75,90$

Rico formation, distribution of $32-33$,

fossils in lithology of section in. stratigraphic relations of pls. $5, A, 6, A$

San Rafael group, features of. $33-34$

San Rafael River, description of

San Rafael Swell, altitude of. structure of $96-97$, pl. 2,20

Shinarump conglomerate, distribution of 58 , fossil wood in pls. $6, B, 10, A, 14$

lithology of stratigraphic relations of Sinbad limestone, description of. 60

Springs in the area, formations containlist of ing

12,14

Stratigraphy in the area

$12-14$ 22-94,

pls. 3, 7, 8

Structure in the area 94-106, pl. 2, 20

Surface features in the area 6-9, pls. $4, A, 5,6,9, A, 10,11, A, C, 12, B, 15,16$
Summervilie formation, distribution of.

PAGE

84

pls. $16,18, A$

lithology of $84-85$

stratigraphic relations of.

Sweetwater dome, description 98-99

Tanks, location of

$15, \mathrm{pl} .1$

Terrace deposits, distribution of $92-94$, pl. 16

Travel in the area, routes of ..18-19, pl. 1

Vegetation in the area.

Water supply of the area. 10-15, pl. 1

Well records 113-120

Whitbeck Knoll anticlinal nose, description of

White Rim, location of.

White Rim sandstone, distribution of........ $44-45$, pls. $11, C, 12, B$

lithology of 44-47, stratigraphic relations of pls. $7,8,10, A, 11, C, 12, B$ ..... 47-48, pls. $8,10, A$

Wingate sandstone, distribution of 64 , pls. $10, B, 12, B, 14$ lithology of $64-65$ stratigraphic relations of 